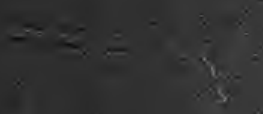




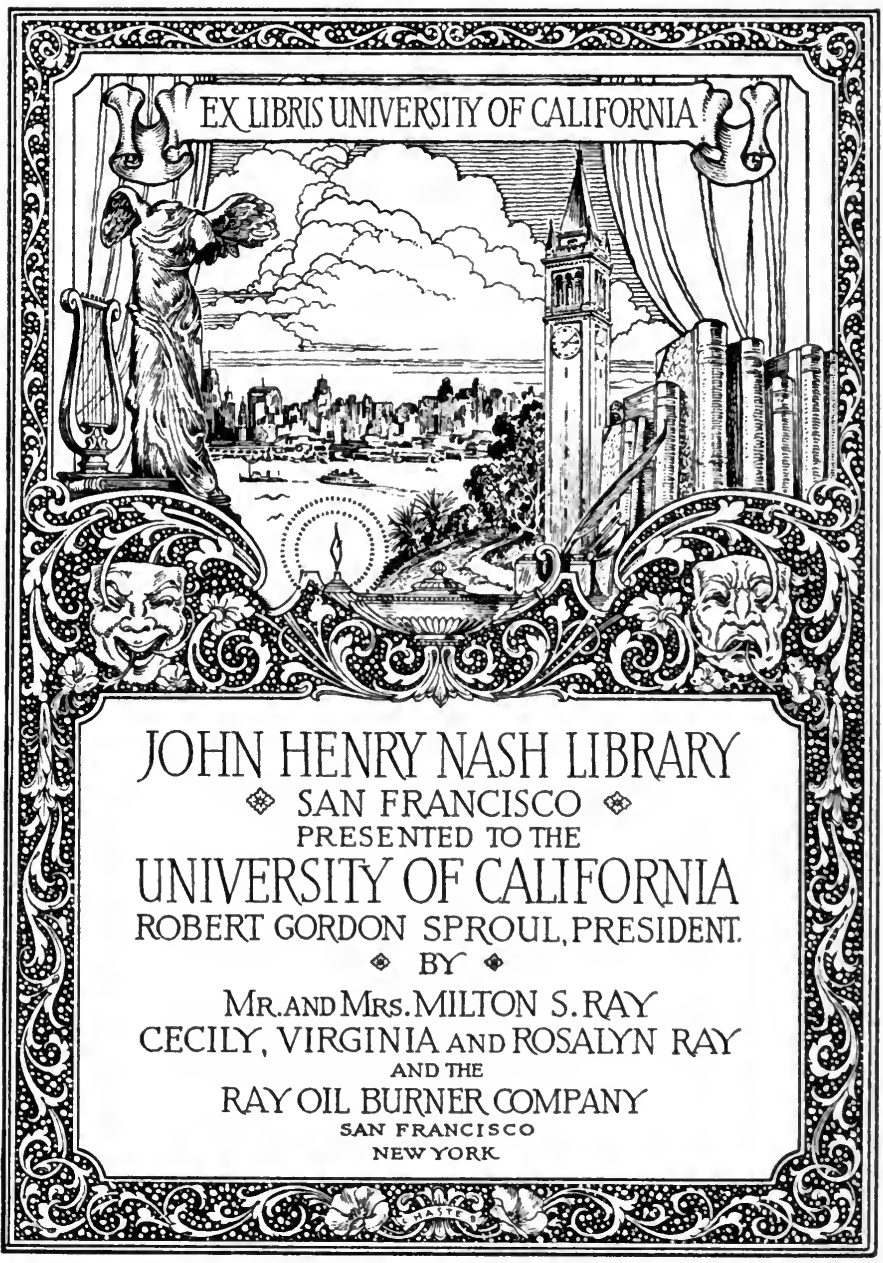




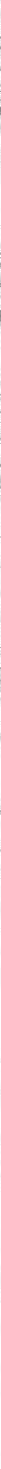

a

in.

$+2$

a

to

Ex

the

(1)

$\therefore$

xin

sis

$\therefore$

a

$\therefore$

स.

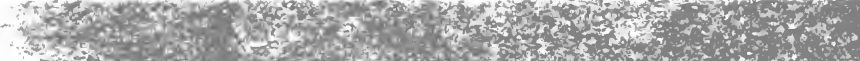

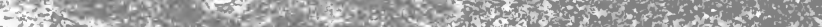

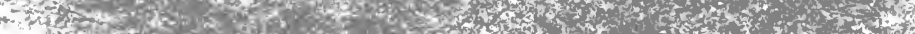

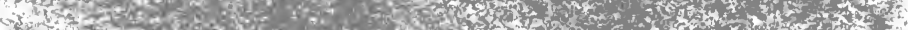
fin

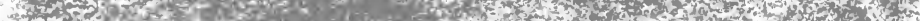

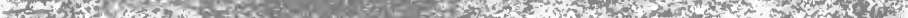

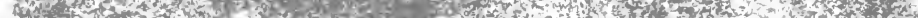
W

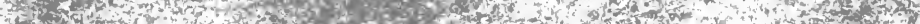
20.

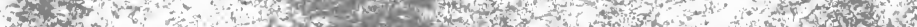

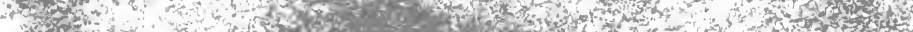
-7 a

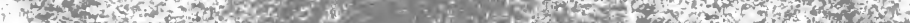

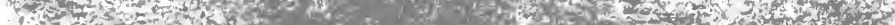

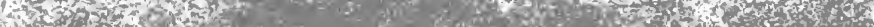

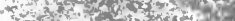

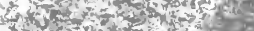

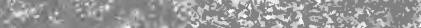

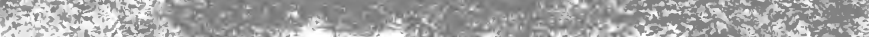



Books about Books

Edited by $A$. W. Pollard

The Binding

of Books 
Digitized by the Internet Archive in 2007 with funding from Microsoft Corporation 


$$
\text { : }=
$$




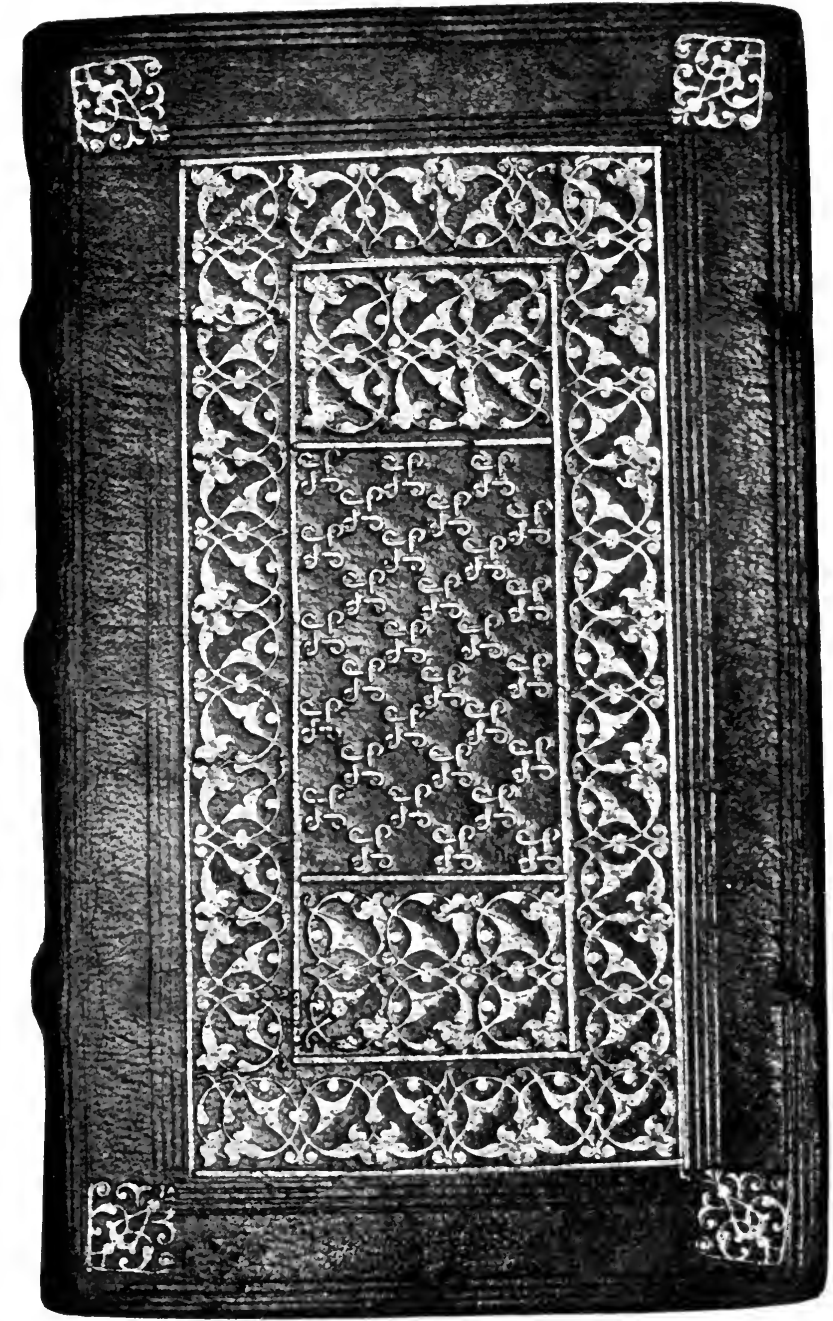

CAESAR.

(GIUNTA, FLORENCE, 1514.) 


\section{The Binding of Books}

An Essay in the History of

Gold-Tooled Bindings

\section{By Herbert P. Horne}

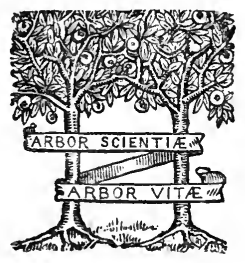

Second Edition

\section{London}

Kegan Paul, Trench, Trübner $\mathcal{E}^{2}$ Co., Ltd.

Broadway House, 68-74 Carter Lane, E.C. 
Second Edition, revised and corrected First Edition, 1894

The rights of translation and of reproduction are reserved 
TO

T. J. COBDEN SANDERSON 



\section{Preface}

'LA Reliure est un art tout français.' Such is the sentence which M. Ernest Thoinan places upon the title-page of his admirable work, Les Relieurs Fransais ; and which, in a particular sense, is abundantly true. In France, alone, has bookbinding been continuously practised, and encouraged, as a fine art, since the Revival of Learning : and in that country, alone, does there exist any considerable literature upon its history and methods. In this sense, bookbinding is an art almost peculiar to France : and yet not to France, but to Italy, must be conceded, both the introduction of gold-tooling into Europe, and the origin of the taste, which determined the nature of the designs used upon European tooled bindings, for nearly a century. Indeed, it might be questioned, whether early Italian bindings have yet been surpassed in beauty and decoration, by those of other times or countries: but be this as it may, the literature of the art remains wholly in the hands of the French. The Italians have neither collected nor written anything considerable upon this subject; the Germans, as their fashion is, have been more industrious than discerning: while English works 
are, perhaps, numerous enough, but not always very critical, or very conclusive. Some exceptions, however, are to be made in the case of a few scattered essays on particular subjects, and, especially, in regard to Miss Prideaux's excellent Bibliography of Bookbinding, London, I892, which, as she very properly observes in her preface, is the first step towards the methodical study of this subject. But a general history and criticism of the art in Europe still remains to be written : and before this can be done with any completeness, the documents, which relate to English, and especially, to Italian, binders and binding, omitting those of other European countries, must be collected and examined, with the same diligence and judgment, as the documents which relate to the French binders.

In writing the first and last chapters of the present essay, which chiefly treat of the technical methods of bookbinding, I have used a number of authorities. The earliest technical works upon Bookbinding are not easily accessible, and are chiefly known on account of an allusion to them in a later work, entitled: L'Art du Relieur-doreur de Livres. This treatise was written by M. Dudin, at the request of the Académie Royale des Sciences to be included in their Description Générale des Arts et Métiers, and was published at Paris, in I772. 'J'avouerai cependant,' says the writer in his preface, 'qu'il m'auroit été impossible de joindre cet art à ceux de l'Académie, si, aux lumières que j'ai tirées, d'un Manuscrit de 


\section{Preface}

M. Jaugeon, appartenant à l'Académie, \& du petit ouvrage de M. Gauffecourt de Lyon, je n'avois eu le secours de M. le Monnier le jeune, Maître Relieur, \& Relieur de S. A. R. Mgr. le Duc d'Orléans.' Three copper plates, in large folio, had been engraved for the work of M. Jaugeon, which still remains in manuscript; and these were used by M. Dudin, being severally numbered 8 , IO, and II, in his treatise, and are signed with the name of Ludovicus Simonneau, and dated 1694-7. This manuscript, which is preserved in the Bibliothèque Nationale [Fr. 9I57 and 9I58], was intended by the Académie des Sciences, to have formed the last part of a work entitled : Description et Perfection des Arts et Métiers : a design, which was afterwards accomplished by that body, in the Description Générale, the first portion of which was published in $\mathrm{x} 76 \mathrm{r}$.

The printed book, to which M. Dudin refers, was written by Jean Vincent Capronnier de Gauffecourt, born at Paris in 1692, and an amateur of printing and binding, which arts he practised in his country house at Montbrillant, near Geneva. It is entitled : Traité de la Reliure des Livres, and was published at Lyons, without date, or place, in April, I763. The author, in an introductory epistle, says, that it was printed by himself, ' pour faire usage de son heureuse oisiveté.' Only twenty-five copies were printed and the little work is chiefly remarkable for its extraordinary rarity, and for the circumstances of its production. An interesting account of Capronnier 
de Gauffecourt is to be found, under his name, in the admirable work of M. Thoinan. Another early treatise in French, exists in the article upon Binding, in the Dictionnaire Universel de Commerce, d'Histoire Naturelle, d'Arts et Métiers, by Jacques SavaryDesbrulons, Paris, I730.

In England, John Bagford seems the first to have attempted some methodical account of the art ; and two essays by him, which had long remained unprinted among the Harleian Manuscripts [Nos. 5910, pt. i., and 5943], can now be read in the Transactions of the Bibliographical Society, vol. vii. pp. I3I142. The earliest important work on the subject, which appeared in this country, was the Bibliopegia; or, The Art of Bookbinding, in all its Branches, by John Hannett, first published at London, in I835, under the pseudonym of John Andrews Arnett; a book which has passed through several editions, and has been translated into German. A more recent work is The Art of Bookbinding, London, I880, by Joseph W. Zaehnsdorf; a second edition of which appeared in 1890 , Other technical works in English, French, and especially German, may be found enumerated in Miss Prideaux's Bibliography of Binding.

I have consulted the greater number of these printed books, especially the treatise of M. Dudin, and Mr. Zaehnsdorf's handbook, which admirably illustrates the practice of the commercial bookbinder, at the present time. To these, I should add 


\section{Preface}

two papers by Mr. T. J. Cobden Sanderson, which I have freely used: the first is an abstract of a lecture upon bookbinding, given in I889, at the Edinburgh Meeting of the National Association for the Advancement of Art, which is to be found printed among the Transactions of the Society for that year; the second is an article entitled Bookbinding, which was published in the number of the English Illustrated Magazine, for January, I89I.

In the chapter upon early Italian bindings, I have not had the advantage of any general authority; unless the Catalogue of the Exhibition of Bookbindings at the Burlington Fine Arts Club, London, I89r, may be reckoned as such. The plates, which occur in the large-paper copies of this work, render it of great value in the general history of bookbinding, and I have constantly referred to it. The excellent introduction to the Catalogue has lately been republished by its author, Miss Prideaux, with the addition of her Bibliography and other papers. The Facsimiles of choice examples of Historical and Artistic Bookbinding, London, I889, published by Mr. Bernard Quaritch, is a smaller work of the same kind, and is chiefly valuable on account of its plates. M. Le Roux de Lincy's Recherches sur Jean Grolier, Paris, I866, and M. Henri Bouchot's Les Reliures d'art à la Bibliothèque Nationale, Paris, I888, are the only other books of which I have made any general use. My principal authority in writing the chapter on French bindings, has been M. Thoinan's work, 
Les Relieurs Français, Paris, I893. This book, together with M. Léon Gruel's Manuel Historique et Bibliographique de l'A mateur de Reliures, Paris, I887 ; MM. Marius-Michel's La Reliure Française depuis l'invention de l'Imprimerie jusqu'à la fin du xviiie siècle, Paris, I880; and M. Alexandre Quentin Bauchart's Les Femmes Bibliophiles de France, Paris, I886; have been constantly referred to by me in the course of this chapter. The materials, which have hitherto been collected for the history of gold-tooled binding in England, are few and inconsecutive: and the one general authority on this subject, of which I have been able to make any considerable use, consists in three articles on English Bookbindings, which appeared in the numbers of the Portfolio for March, April, and May, I893; and which have since been reprinted with other essays under the title of Some Minor Arts as practised in England, London, I894. To the writer of these papers, the late William Younger Fletcher of the British Museum, I am, also, indebted for no little assistance received while writing this essay. Other authorities are given, as they occur, in the text.

The bindings, of any nation are, perhaps, only to be completely studied in the country, in which they were produced: certainly, the art of the French bookbinder is nowhere to be seen as in Paris, among the books of the Bibliothèque Nationale, and other public and private libraries. Apart, however, from the unrivalled assemblage of English bindings, 


\section{Preface}

which are preserved in the British Museum, we possess in that collection, an admirable series of French and Italian bindings : and in order to make the present volume more generally useful to the 'amateur' in this country, I have endeavoured, in so far as it is possible, to entirely illustrate my meaning by examples in our National Museum; adding the press marks of the books in brackets. A certain number of these bindings will be found reproduced in two works by W. Y. Fletcher: English Bookbindings in the British Museum, published in I895, and Foreign Bookbinding in the British Museum, which appeared the following year.

It remains for me to add, that I have endeavoured to write about my subject, not merely as an antiquary and a critic, but as an artist; for the art of bookbinding is yet a living art, capable of new motives and new forms of expression. 



\section{Contents}

CHAPTER I

The Craft of Binding, . . . . . I I

CHAPTER II

EARly Italian Bindings, . . . . 55

CHAPTER III

French Bindings, . . . . . 99

CHAPTER IV

ENGLISH BINDINGS, . . . . . ${ }$ I64

CHAPTER V

Conclusion, $\quad . \quad$. $\quad . \quad$. 2 . 216 


\section{Illustrations}

Plate

I. Florentine Binding, . . . . Frontispiece

A ' Cæsar,' printed by Filippo di Giunta, I 5 I4.

II. Back of a Canevari Binding, • • • 9

Polydore Vergil : 'Historia Anglica,' Basle, I534.

III. BINDING FOR GROLIER, • • • • 79

Bembo's 'Gli Asolani,' Venice, I 530.

iv. Florentine Binding, . • • . . . 97

A manuscript of 'Onosander.'

v. BINDING BY GeOfRoy TORY, . . . . 109

A 'Petrarch,' Venice, 1525

vi. Binding by Nicholas Ève, . . . . I2I

A 'Horace,' Venice, 1581 .

vii. Binding by Roger Payne, . . . . 210

'Euripides,' Cambridge, I694.

viil. Binding by Mr. Cobden Sanderson, • . 214 Shelley's 'Adonais.'

IX. Binding by Mr. Douglas Cockerell, . . 215

An Eton 'Roll of Honour.' 


\title{
BOOKBINDING
}

\author{
CHAPTER I \\ THE CRAFT OF BINDING
}

IF we would understand a fine art, with that completeness, which its criticism requires, it is necessary, that we should first be acquainted with its various technical methods, especially in so far as these control, and determine, the nature of the design and workmanship employed in its productions. A fine example, not only of the bookbinder's, but, also, of every other, art is directly the result of the limitations imposed upon the skill and taste of the workman, by the process of his craft, and by the materials used in its practice. To appreciate these limitations in the binder's art, we must follow the various stages through which a book passes, in his hands ; or, at least, for our present purpose, as many of these as are necessary to the production of fine and sumptuous bindings.

FoldING.-If the book is in sheets, or 'quires,' the first stage, through which it passes, is that of folding. This is effected by an instrument called a folding stick: and great nicety is requisite, or the 


\section{Bookbinding}

book, especially if its margins are small, will be seriously damaged, when its edges are cut; a fault, which we find even Le Gascon committing, according to the letters of Peiresc. If the printer has justly 'imposed his forme,' and the folder correctly done his part, the fields of the type will coincide, and the several margins be equal, throughout the book. A sheet, or quire, thus folded is called a section: the top of the sheet is called the head; the bottom, the tail; and the front edge of the sheet, the fore-edge. If the book has already been cased, or bound, then it is first pulled to pieces, or divided. The glue is removed from the back, the threads with which the book is sewn are cut, and the sections, as they are pulled apart, are laid evenly one upon another.

When the binder comes to pull in pieces a modern book, which has been cased, that is to say, temporarily bound in cloth, or paper, he often finds, that the sections have been irreparably damaged. This injury is the result of the casing having been viciously done, and without regard for the permanent binding, which is likely to supersede it, if the book is of value. A volume temporarily bound should be folded as carefully as a book permanently bound; but it should not be pressed, or rolled, or beaten. It should be sewn, but it should not be sawn; and the back should be left intact. Neither single sheets, nor any sections, should be pasted on, or overcast ; but sewn with the rest of the book; the 


\section{The Craft of Binding}

former having first been mounted upon guards. The end-papers, moreover, should not be pasted on, but sewn with the quires of the volume. For this purpose, additional sections of plain paper, similar to that on which the book is printed, should be supplied by the publisher. The book should not be rounded; still less should it be backed, which is an unnecessary operation in temporary bindings, and often the cause of irreparable mischief. In permanently binding a book, this temporary backing has to be struck out with the hammer; and the sections, when backed a second time, are apt to take their old form, which in most cases is the wrong one, having been fashioned without proper care, or by machinery. Lastly, the edges of a cased book should not be cut. In brief; nothing should be done in temporary binding, but what is necessary ; and what is necessary should be perfectly done.

Collation.-The next stage is the collation of the book, to ensure that all the sheets are in their proper sequence, according to the signatures of the several quires, or sections. In our modern practice, these signatures generally consist of letters, which are placed at the foot of the first page of each quire. The signature of the first quire of the text is ordinarily $\mathrm{B}$, the title-page and preliminary matter being reckoned as $\mathrm{A}$. The letters $\mathrm{J}, \mathrm{V}$, and $\mathrm{w}$, are not often used; and when the remaining letters of the alphabet have been exhausted, AA is used for a second, Aa for a third repetition. Particular atten- 
tion must be given to the collation of any inserted leaves, for which special directions are generally furnished to the binder. The collation of old books, where irregular signatures are frequent, obviously requires peculiar knowledge; but the principles of collation may best be understood, by reading such a volume as Mr. Jacobi's admirable little volume of Notes on Books and Printing, or the French treatise of Dudin mentioned in the Preface, where such matters are set forth at length.

Beating, or Pressing.-Formerly, after the book had been collated, it was beaten. For this purpose, a beating-stone and hammer were used: the beating-stone, which, despite its name, was sometimes an iron slab, was securely bedded, and possessed a perfectly smooth face. The hammer was smallhandled, and heavy-headed. That end of the head, which was used for beating, was considerably larger than the other; and, like the stone, required to be perfectly smooth, and scrupulously clean. Two or more sections of the book, according to their thickness, were then laid on the stone, between two sheets of paper, and equally beaten over the whole of their surface. To ensure this equality, the sheets were continually moved round by the left hand; while the hammer was held in the right. Unless great care was taken, that the face of the hammer should fall evenly upon the surface of the sheets, the edge of the hammer was apt to break the paper. After the book had thus been beaten in separate 


\section{The Craft of Binding}

portions, the whole of the sections were gathered up, and beaten together, for a second time. In recent years, rolling machines have been invented to do the work of the beating hammer; and all books, with few exceptions, are now rolled, whereby a great saving of labour is effected. For ephemeral and commercial work, the value and efficiency of such machines are certainly very great: but neither fine, nor old, books should on any account be rolled. In a new book, the texture of a hand-made paper will certainly be damaged, if not destroyed, by the process of rolling: and in many an old one, the deep impression of the type into the paper, is likely to make it split under such treatment. The use of the beating hammer, on the other hand, requires great skill and judgment; or the sections will be bruised and cut. The risk of treating a valuable book in this manner is too great to warrant its employment, even by an experienced workman ; especially as another method, both safe and effective, remains in the use of the press. But this, like every other operation of the binder's art, requires a nice judgment : and the sections of a book should be pressed sufficiently to render them solid, and to keep out the dust; but not to the degree, at which the paper is killed.

MARKING UP AND SEWING.-The head, and back, edges of the sections are now knocked even, that is, they are brought to an even surface ; and the book is ready for the process, technically known as mark- 
ing up. This consists in spacing out, and marking upon the back, the position of the cords, upon which the book is to be sewn. For this purpose, the book is placed, with the back uppermost, between boards, in a lying-press; and the position of the cords is then marked on the back with a black lead pencil, by the aid of a right-angled set-square ; their proper number and distribution being a matter of the greatest importance, in good binding.

There are two methods of sewing a book; one of which is known, as sewing round the cords, and the other, as ordinary sewing. In sewing round the cords, the construction of the binding usually determines the decoration of the back: in ordinary sewing the construction is either hidden, or falsified. Sewing round the cords is not only the more artistic ; but it is the stronger, and better, method; and the one, which I shall describe. In ordinary sewing, the cords are embedded in a series of grooves, cut by a saw; and the books of the present day are, with rare exceptions, sewn in this manner. Derome was, perhaps, the first binder of repute, who employed this dangerous use of the saw; and the method of his time may be found described at length, in the treatise of Dudin. In modern books, ordinary sewing is generally accompanied by the use of hollow backs, partly on account of the great saving of labour, which is effected by their use, and partly on account of the excessive thickness of the paper used in modern books, which necessitates the 


\section{The Craft of Binding}

use of this method. There will be occasion, hereafter, to speak of the taste, which gives to the backs of contemporary bindings an unp?easing roundness, and to their squares an unnecessary projection: the same gross taste determines the choice of the paper on which they are printed. If the book be small, and the paper be thick and hard, it is not possible to make a good binding. The early Italian printers selected their papers according to the sizes of the books, for which they were intended to be used; but the modern English printers endeavour to give a pretentious appearance to the slightest productions of their presses, by the use of heavy leads, and thick paper. The sheets of a folio by Torrentino, or of an octavo by Giunta, how admirably well is their substance chosen in relation to their size! The Catullus, Tibullus and Propertius, edited by Graevius, and printed by Rudolphus a Zyll, in 1680 , although it contains nearly 1400 pages, measures scarcely more than two inches across the fore-edge, in its contemporary binding: whereas a book of the same number of pages, printed upon the paper used in some costly modern editions, would measure rather more than five inches, across the fore-edge. Yet what more beautiful paper could be desired, than that on which the volume of Rudolphus a Zyll is printed ?

In marking the position of the cords upon the back of the book, the spaces between them are generally made equal; and smaller than the re- 


\section{Bookbinding}

maining spaces at the head and tail of the volume. This difference is necessary, that these spaces at the head and tail may appear to be in relation with those between the cords; otherwise, owing to a curious optical illusion, the latter would appear larger than the former : but their precise number and distribution is to be determined by the nice sense of the workman, according to the nature of the book to be bound.

In many early books, especially in Italian books of the fifteenth and sixteenth centuries, double bands were used, which lend an uncommon richness to the back, when it is covered and finished. Both cord and leather were employed by the binders of the fifteenth century, for the bands. An early example of a book sewn upon cords may be seen in a copy in the British Museum [IC. 4078], of the Moralia in Job, of St. Gregory, printed by Conrad Winters at Cologne, about 1475 . When the bands were double, and leather was employed, a single strip was divided in the centre, by an incision equal to the width of the back: on this, the book was sewn, as upon double cords; the slips being thus left single; as on a copy of the Sermones Hyemales, of Soccus Deventer, I480, [IB. 47507], in the same collection.

The cords are first secured in the sewing press, which consists of a wooden bed with two upright screws, regulating a beam or cross bar, round which are fastened as many loose rings of cord, called lay cords, as there are cords to be used in sewing the book. One end of a cord is then tied to one 


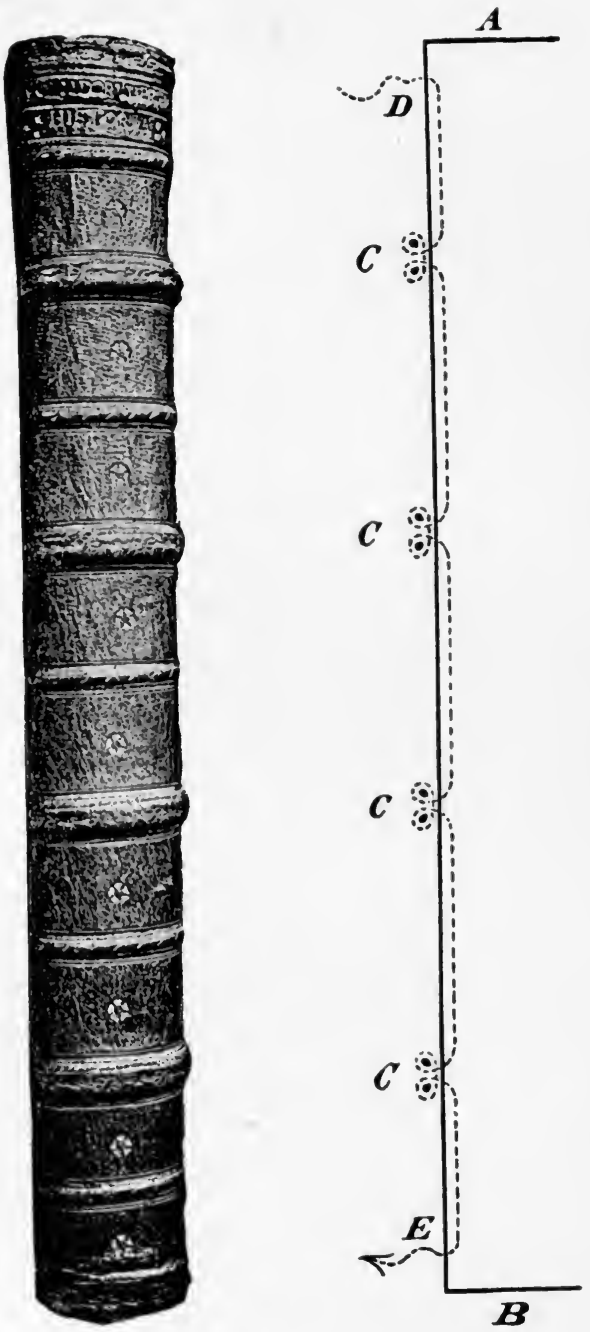

BACK OF A CANEVARI BINDING.

(POLYDORE VERGIL: 'HISTORIA ANGLICA,' BASLE, 1534.) 


\section{The Craft of Binding}

of the lay cords, and the other end of the cord is next fastened to a small piece of metal, called a key; which moves along a slot in the bed of the press, immediately beneath, and parallel with, the beam, or cross bar: and in this manner, all the cords are secured in the press. The book is then laid on the bed of the press, with the back next to the upright cords : and the keys are moved to and fro in the slot, and the lay cords to and fro along the beam, until the position of the cords exactly coincides with the pencil lines, which have been marked on the back of the book. When they agree, the press is screwed up ; and everything is ready for the sewing. In order to illustrate the method by which a book is sewn, the back of an early Italian binding, with double cords, is here figured by the side of an explanatory diagram. [Plate II., fig. I and 2.] A, in fig. 2, is the head, and B the tail, of the first section, which is now laid on the bed of the press with the pencil marks on its back touching, and coinciding with, the double cords, C, C, C, C, C. A needle and thread is passed, by the kettle-stitch hole, $\mathrm{D}$, within the central pages of the sheet; and is thrust out between the two cords, which make the first band, $C$. The thread is then carried in such a way, indicated by the dotted line in the diagram, as to make a complete circle round each of the cords ; after which it is again introduced within the central pages of the section. The remaining cords having been sewn in this manner, the thread 
is finally taken out at the kettle-stitch hole, E. The second sheet is now placed above the first, and sewn in the same way; but reversely, from tail to head, instead of from head to tail. When the thread is taken out by the kettle-stitch hole, D, of the second sheet, it must be fastened by a knot to the end of the thread, which should be hanging from the same hole of the first sheet. The third sheet is then sewn like the former ones; but when the thread is taken out by the kettle-stitch hole $\mathrm{E}$, the needle is thrust between the first and second sheets, and is drawn round the thread, which passes from one kettle-hole to the other; thereby fastening the sheets by a kind of chain stitch : indeed, the term, kettle-stitch, according to the Oxford English Dictionary, is an adaptation of the German Kettelstich, in which Kettel means a small chain. A book must be sewn by a continuous length of thread; but the bulk and numbers of the sections usually necessitate the use of two, or more pieces joined together : and when all the sections have been sewn, the end of the thread must be properly secured at the last kettle-stitch hole. In theory, the sewing of a book is the simplest of operations; but in practice, it requires a skill and judgment, which can only be appreciated by experiment. The thickness, both of the cords, and of the thread, are to be chosen according to the size of the book, and the nature of its paper: and the tension of the thread varied in the several parts of the sewing. In some early 


\section{The Craft of Binding I I}

bindings, according to Mr. Zaehnsdorf, in his Manual of Bookbinding, the headbands, which I shall describe in their place, were formed during the process of sewing; 'by fastening other pieces of leather for the head and tail, and making it the catch-up [or kettle-] stitch as well ': but it was necessary to cut the edges of a book treated in this way, before it was sewn.

English binders, on account of the hard paper used in modern books, usually overcast the first and last sections; that is, they sew them over, as if they were single sheets. Sections treated in this way, are afterwards pasted up, or secured with paste, by the edges of their backs to the next sections. But this method is greatly to be deprecated; for when these sections break away, which invariably happens, if the paper be hard, and the book be much used, they are so damaged, that they require to be mounted upon guards, if the book be rebound. All single sheets should be mounted upon guards ; and both these, and the end-papers, should be sewn with the sections; so that the entire book may open to the quick, from board to board. A simple device employed by many binders of the fifteenth and sixteenth centuries, effectually prevented the body of the book breaking away from the end-papers. A sheet of vellum was laid between two sheets of paper; and the whole was then folded and sewn in the usual way, with the other sections of the book. The outer paper and vellum 


\section{2}

\section{Bookbinding}

leaves were next pasted upon the boards of the book; while the four remaining leaves were left free, as fly-leaves. This method is commonly to be found employed, in the bindings of Grolier: and an earlier example may be seen in the copy of the Moralia of St. Gregory, already mentioned.

In sewing a book round single cords, the method is precisely similar to the foregoing: except that the thread makes a complete circle round one, instead of two, cords. In ordinary sewing, a series of grooves is cut with a saw, across the back of the book, in which the cords are embedded: so that the needle and thread, after being inserted at the kettle-hole stitch at the head of the section, are passed in a direct line, within the fold of the sheet, and without the back of the cords, to the kettlestitch hole at the tail. In other particulars, this kind of sewing does not differ from that of sewing round the cords: but neither fine, nor old, books should be sewn in this manner; as the sections are always more or less damaged by the saw, in the process. There are a number of variations upon these two methods of sewing: but none is of importance, and most are inferior, being contrived to save either time, or trouble.

END-PAPERS.-The choice of the end-papers is next to be considered. Coloured end-papers appear to have been first used towards the end of the sixteenth century; before which time they were commonly made of vellum, or white paper. If a 


\section{The Craft of Binding}

book be printed on a fine hand-made paper, the same paper may be used for its fly-leaves and endpapers: and, perhaps, there is no more pleasing method to be found, especially if the binding be richly tooled. Some of the earliest coloured papers are in stamp, and bear small patterns, in repeat: one, two and even three, wood-blocks being used in their production. Of these papers, the greater part are probably Dutch, or German; although many are by English makers: but the Italian are the most beautiful, often bearing little patterns devised on a geometrical basis. In working these Italian papers, the colour was used in a very liquid state, producing a certain blotted effect, which is remarkable, also, in the woodcuts of Ugo da Carpi, and the great masters of chiaroscuro printing. Such papers as these were used for many other purposes, besides that of end-papers. In the eighteenth century, they were used with effect, for covering the boards of inexpensive bindings. They appear to have been made throughout Europe: I remember, for instance, to have seen one made in the eighteenth century, at Orleans; but the name of the maker had been cut away. During the same century, and perhaps earlier, certain gilt papers were printed in Germany; upon the margins of which, I have noticed the names of 'PAUL REIMUND IN NURNBERG' and of 'IOHANN WILHEI.M MEYER IN AUGSPURG.' In their manufacture, the paper was, in some instances, first covered with a single colour; while, 
in others, perhaps the earlier examples, a kind of mosaic of bright colours, of yellow, vermilion, purple, blue and green, was formed by a sponge over the whole surface of the sheet; or a chequer of the same colours was formed by a series of broad lines crossing one another: a ground was then stamped in gold-leaf upon a sheet prepared in this way; and a parti-coloured pattern was left in relief. The design of such papers was not repeated; but varied over the whole extent of their sheets. Other papers, made in the last century, bear designs of scroll work interspersed with figures, beasts and birds, printed in gold upon a green back-ground: they are of a very handsome appearance; and are probably of German origin. In recent years, a great number of patterned end-papers have been designed and printed from wood and zinc blocks in England; of which the most inventive and beautiful is that designed by Dante Gabriel Rossetti for the volumes of his poetry.

During the seventeenth century, the Italians contrived a peculiar arrangement of their end-papers. In an example before me, the inside of the boards is covered with violet silk; the book itself being bound in black morocco: either end-paper, next the silk, is ornamented on both sides with a large pattern of a Venetian character, printed in gold and black upon a ground of the same colour as the silk; and the fly-leaf, which follows, is of white paper. In other examples, the end-papers, cover- 


\section{The Craft of Binding}

ing the boards, alone are coloured, the fly-leaves being plain.

The marbling of papers is no doubt an inferior art to that of ornamenting them with designs in stamp; and it is, moreover, an art fallen, deservedly, into disrepute, on account of the merely commercial use, which, for the most part, has been made of it : but, in capable hands, it has produced effects in colour, which are of real beauty, and worthy of admiration. The process of the art, as it is ordinarily practised, may be found set forth, with great particularity, in a little treatise by C. W. Woolnough, entitled: The Art of Marbling, as applied to book edges and paper; the first edition of which was published in $\mathrm{I} 853$, and the second, in $\mathrm{I} 88 \mathrm{I}$. In the opinion of this writer, the earliest marbled papers date from the beginning of the seventeenth century: these he believes to be Dutch, and certain 'drawn and antique patterns with stormont and other spots to be the most original.' La Caille, on the other hand, in his Histoire de l'Imprimerie, Paris, I689, attributes the invention to Macé Ruette, the French binder. But there is a passage in the Sylva Sylvarum of Francis Bacon, published at London in 1627 , [Century viii, 74I.] which seems to point to the true origin of the art. 'The Turks,' he says, 'have a pretty art of chamoletting of paper, which is not with us in use'; and adds a brief description of the method. Although marbled paper was not made in this country, at the time at which 


\section{I6 Bookbinding}

Bacon wrote, it had been used in Germany at the end of the previous century. The Album Amicorum of Joannes Cellarius, of Nuremberg, preserved in the British Museum [Add. Ms. 27, 579.], bearing the date I599, contains nine leaves of marbled paper, which are probably the earliest dated examples extant. Other early specimens may be found in other albums, of which the Museum possesses a great number: and a collection of marbled and coloured papers, formed by John Bagford, exists, also, among the Harleian Manuscripts [No. 5940.]. The marbled papers manufactured at the present day, for commercial purposes, are not comparable to these early examples; being made without taste, according to the perfunctory receipts of the trade. Of recent years, however, efforts have been made to revive the art, and often with considerable success.

Another kind of paper, called coloured pastepaper, is more easily prepared, than marbled paper, and has a very tolerable effect. Some colour is mixed with paste and a little soap; and then spread with a brush over two sheets of paper. These, while still wet, are brought face to face, and, when separated, present a mottled appearance.

The use of silk, in covering the fly-leaves is, I think, to be deprecated, as the substance of a leaf thus formed, to say nothing of its cut or folded edge, does not agree with that of the other leaves of the book: but there is not the same objection to the use of this material in covering the panel, 


\section{The Craft of Binding}

on the inside of the boards. The only rule, which can certainly be laid down with regard to endpapers is, that they should err rather in being too many, than in being too few. There should always be at least two fly-leaves, at either end of a book, in addition to the paper which covers the board: for no volume has a meaner appearance, than that which opens immediately upon the title.

BACKING.-The book is now placed in the lyingpress, that it may be glued up: and the binder must decide upon the nature of its back, which may be either rigid, or flexible ; or which may vary, as do the greater number of old backs, in some degree or other, between the two. But it will be well, first, to describe in this place, the tub, the lyingpress and the plough. The tub is an open box, or receptacle for the waste, the ends of which are raised to a convenient height in order to carry the lying-press, which rests upon them. This press consists of two heavy, oblong, blocks of wood, which are regulated by two wooden screws. The upper face, or cheek, of the block on the left hand of the binder, is furnished with a groove, in which the plough runs. This machine, which is used in trimming the boards and edges of a book, is constructed on the principle of a knife cutting against a straight edge. It is capable of two motions : by the first, the whole plough is worked to and fro over the press, being kept in its place by the groove on the left cheek; by the second, the knife of the 


\section{8 Bookbinding}

plough, which moves above the right cheek of the press, is gradually brought nearer to its left cheek, by the means of a screw. Many elaborate cutting machines have been invented in recent times, but of them there is no present occasion here to speak.

If the back is to be rigid, a piece of leather is usually glued, in the better kind of modern work, along the whole of its length. Books bound in calf, generally have rigid backs, on account of the liability of that leather to split and break away: but the paper of such books should be of a nature, that will allow the leaves to fall by their own weight, when they are opened. The hard paper, upon which so many contemporary books are printed, will not permit the use of this method, which is not altogether to be commended. But if the book is to have a flexible back, there are two ways in which it may be treated: either the covering may be directly pasted upon the back; or it may be left detached, in such a manner, that, when the book is opened, the back shall spring inwards, while the covering shall bulge outwards; a hollow space being formed between the two. A volume treated thus is said to have a hollow back. Many old books, covered in vellum, especially during the seventeenth and eighteenth centuries, were bound with hollow backs, on account of the unyielding nature of that material: but they were generally sewed on flat slips of parchment, or leather, which were pressed 


\section{The Craft of Binding}

into the back, when it was glued up, so as not to show. These slips were then taken externally over the hinges of the book, through the vellum covering, before they were secured to the inner side of the boards: and no indication of the bands was left upon the back, which was often unornamented, except by the inscription of the title in pen and ink. In some examples of the sixteenth century, this was written in a large, decorative, hand along the back of the book, from the head to the tail. Books are, now, rarely bound in vellum, after this fashion, which is to be commended, by reason of its strength and durability: but the use of hollow backs in leather-bound books, where the cords cannot thus be laced through the covering, is scarcely to be approved. True, it is, that the nature of a hollow back is such as to form a kind of spring, which greatly assists the opening and shutting of a book, when the leaves are of a hard or heavy paper; but the joints in this kind of binding must always be weak. At the present time, all books are, with the rarest exceptions, bound with hollow backs; the price at which the work is to be done, and the nature of the paper upon which the books are printed, necessitating the use of this method. In casing, or cloth binding, in which cheapness and a certain durability are the only considerations, hollow backs are certainly to be commended, since they easily fulfil their purpose: but in fine and sumptuous binding, they ought not to be used. 


\section{0 \\ Bookbinding}

For not only, as I have said, are the joints of such bindings weak; but the nature of their backs leads to the use of false bands, by way of ornament, which often do not represent either the number, or the position, of the cords upon which the book is sewn. Fine ornament should always be suggested by the construction of that, which it is to decorate: ornament, which masks or falsifies construction, deviates from the nature of fine art, according to the degree and manner, in which this is done. And so, I think, in forming the back of a book, the most artistic method is to turn the natural projection of the bands to the uses of its decoration: although many of the greatest French binders of the sixteenth century, and especially those, who worked in the styles, called after Nicolas and Clovis Eve, used to conceal the cords of their books. These binders commonly employed flat strips of parchment, or leather, upon which they sewed their sections, and which they afterwards pressed into the back, as in the case of the vellum bindings, already described: so that when the back was covered, it presented a level surface, unbroken by any bands, which they commonly ornamented by some continuous pattern. Such a treatment of the back is most certainly to be allowed, and is very different from the use of false bands, dear to the modern binder: yet, despite authorities as august as the Eves, I cannot refrain from thinking, that the bookbinder, who follows his craft with the fas- 


\section{The Craft of Binding}

tidious temper of the artist, will not seek to hide the construction of his bindings, but will find in such construction the grounds of their proper ornament; and in forming the backs of his books, he will turn the projection not only of the bands, but also of the kettle-stitch, to the purposes of their decoration.

Having decided, that the back of the book shall be flexible, yet not hollow, and that the bands shall be used in the decoration of the back, the binder proceeds to glue up the book, that is, to cover the back with glue, so that the sections may be held together. For this purpose, the book, as I have said, is securely held in the lying-press; the back being uppermost: and the glue is applied with a brush, and rubbed into the back, sometimes with a handful of shavings, and sometimes with the flat end of a hammer. The back, after it has been glued, must not be allowed to get over dry, before it is rounded : but the book should be left, until the glue ceases to be 'tacky' to the touch, and no longer.

Rounding THE BACK.-In rounding the back, the book is placed upon the lying-press, with its fore edge towards the workman. It is then held in such a manner by the left hand, that the upper sections of the book may be drawn over, giving to the back a circular form. The workman now takes a backing hammer, not unlike a shoemaker's hammer, in his right hand, and begins to strike 
the back of the book with the face of the hammer, directing his strokes away from the centre of the back. As he strikes, he still draws over, with his left hand, the upper sections, until the whole length of the book has been treated in this way. It is then turned over, and the same process is repeated on the other side until the proper circular form has been given to the back, which will require the book to be turned over several times, before it can be rounded with correctness. It is very necessary, that a book should be uniformly rounded, as the fore edge, after it is cut, will take the same shape as the back; and any defect in the rounding will thus appear on the fore edge. The degree of roundness to be given to the back of any volume, should be determined by its thickness, considered in relation with its height and breadth; the roundness approaching nearer to a semi-circle, in proportion as these dimensions relatively increase. French binders, at the present day, give to their backs a greater curvature, than is either necessary, or elegant. Only that degree of roundness should be given to a book, which is requisite to prevent its back from becoming concave: for in this one consideration consists the whole reason for rounding the back of a book. A flat back has an indisputable charm; but a book treated in this manner, and subjected to much use, will eventually assume a concave form. Yet in this, as in every other such particular of the bookbinder's art, taste is the best 


\section{The Craft of Binding}

arbiter, and above all rules. Even a concave back may become charming in a small and thin volume.

The next operation consists in backing the book; that is, in forming the grooves, along the back edge of its outer sections, in which the boards are to rest, and their hinge is to be formed. This is effected by means of two strips of hard wood, which are sometimes faced with steel, called backing-boards. These are rather longer than the book; and their upper edges are somewhat farther apart than their lower ones, so that the section of the boards is in the form of an inverted and truncated isosceles triangle. Two of these backing-boards are placed, one on either side of the book, with their upper edges parallel with the back edges of the outer sections, and distant from them rather less than the thickness of the boards. In this position, both the book, and the backing-boards, are lowered into the lying-press, until the upper edges of the boards are level with the cheeks of the press; the whole is, then, securely screwed up. By reason of the triangular section of the backing-boards, the entire pressure of the lying-press is now directed against the sides of the book, exactly where it is intended to form the groove. The back of the book is then struck with a circular motion, away from the centre of the back; in order to bring over the backs of the outer sections, on either side, to the backingboards, which have been so placed, that their upper edges slope away from the book. This process is 
begun with gentle strokes, the back of the hammer being used : but in finishing, the face of the hammer is employed with somewhat greater force, that the sections may be brought well over, and the groove truly made. A dent upon the back, or a wrinkle in the book, when it comes to be opened, is a sign of bad workmanship.

MARKING UP.-While the book is passing through the stages, which I have described, the binder will find time to look to the boards. The use of pasteboards was not introduced into bookbinding until the end of the fifteenth century; and was at first only employed upon books of small size. In the term, boards, for the covers of a book, we have a relic of the wooden boards, which continued to be used on large volumes, during the first half of the succeeding century. The millboards now in use are manufactured in such various qualities, sizes and thicknesses, that it is both impossible, and unnecessary, here to describe them : it is sufficient to say, that the best sort.is made of old rope. A board having been chosen, and marked up in sizes rather larger than will finally be required, is next cut with millboard shears, a certain large kind of shears, made especially for this purpose. In choosing a millboard, its thickness is to be determined by the size of the book, for which it is intended to be used; a particular, which, in no small degree, goes to form the character of a binding. The boards are first lined with a thin, white paper, once upon 


\section{The Craft of Binding}

the outside surface, and twice upon the inside, to the intent that they may curve inward, towards the book. After they have been pressed and are dry, their exact height and width is to be marked upon them by means of a point and a set-square. This height and width is to be determined, by exactly calculating what the size of the book will be, when it is cut; and by adding a certain amount to the head, fore and tail edges, for the squares. The squares are those portions of the boards, which project beyond the edges of a finished book: and the amount of their projection is to be regulated, according to the size and thickness of the book. They are intended to protect the edges, and the least projection, that will effect this, should be given to them. The excessive projection of the squares, in some modern books, is a result of the same reprehensible taste, which indulges in coarsely rounded backs, and coarsely grained leathers, of which I have already had occasion to speak. The boards, having been marked up, according to the required dimensions, are now placed in the lyingpress, and cut by the plough with great exactitude. A simple method of discovering if the boards are in truth, that is, if they have been correctly cut, consists in placing them, reversed, one upon another; when the least inaccuracy will become apparent. If the boards are required to be very thick, they are 'made,' by pasting together two millboards of unequal thickness, the thinner one being placed upon the inside. 


\section{Bookbinding}

LACING. - The boards are now ready to be laced to the book: for this purpose, they are placed in the exact position, which they are to occupy, when they come to be fastened to it. A series of parallel lines is then marked upon the boards, with a point, or pencil, at the various levels of the slips: and, afterwards, another line is drawn upon the boards parallel to the back edge, and distant from it nearly twice the projection of the squares. At each intersection of these lines, a hole is pierced by a bodkin. The board is then reversed; and a second series of holes is pierced in it, equal in number to the first, and at a distance from them, which varies according to the size of the book: in an octavo volume, this distance is about half an inch. The slips are now scraped, pasted and pointed. In this condition, they are passed, over the back edge of the board, through the first hole and back again through the second hole; after which, they are drawn in tightly, and cut close to the board with a knife. This done, each of the boards is, in turn, opened; and the cords, or slips, well hammered on the knocking down iron, to make the holes close upon them, and to prevent any appearance of them, when the book is covered. An interesting account might be written, of the various methods employed by the early binders, in the attachment of the boards to the book. When these were of wood, a series of slots was commonly cut from the first to the second holes, sufficiently deep to prevent the slips from 


\section{The Craft of Binding}

protruding above the surface of the boards: the slips were then laced in the usual way, being secured in the second hole, which did not pierce the board, by an oaken peg. An example of this method may be seen in the copy of the Moralia in Job of St. Gregory, already described. Some binders of the sixteenth century laced their slips through single holes; and strengthened their joints by a vellum hinge, made in the following manner. They cut, in a strip of vellum, equal to the height of the book, and wider than the back by a couple of inches, a series of slots to receive the bands; the length of the slots being equal to the breadth of the back. This strip of vellum was then pasted to the back, between the bands; the slips, having been drawn through the slots, were laced to the boards; and the surplus of the vellum, on either side of the back, was then pasted to the under side of the boards; thereby forming a joint, or hinge. The French binders of the last century used to lace each slip through three holes, and strengthen the back and joints of the book with parchment; a process, which may be found described in the treatise of Dudin. But neither method is as successful, as the device of a vellum end-paper, sewn with the rest of the sections, and pasted down on the board, which I have already described, or a morocco joint, treated in the same manner. But to return to our modern practice: after the slips have been hammered, the back of the book is covered with paste 


\section{$28 \quad$ Bookbinding}

to soften the superfluous glue, which is removed by a piece of wood, called a cleaning-off stick. The back is then rubbed with a handful of shavings; and after it is dry, a tin plate is placed between each of the boards and the book. These plates are to be placed so that they lie in the groove of the hinge : and pressing-boards, of the size of the book, are next laid above and below the book, in the same position as regards its groove, as were the tin plates. The book is now placed in a powerful press, where it may with advantage remain, at least, for a couple of days.

Cutring.-The cutting of a book, the next operation in the process of binding, is a matter of great importance, requiring both skill and care. To cut a book with correctness, it is necessary that the knife should be sharp and true, that the book should be placed accurately in the press, and that both the screws of the press should exercise an equal amount of pressure upon it. The first series of holes by which the boards are laced to the book, having been made at a distance from the back edge of the boards, equal to twice the projection of the squares ; either board can be moved up, or down, until its head, or tail, edge is at the level to which the head, or tail, edges of the book are to be cut. The upper board having been moved down in this manner, and a thin millboard having been inserted between the last section and the lower board, to act as a cut-against, the book is lowered into the press, with 


\section{The Craft of Binding}

the back towards the workman; until the head of the upper board, which indicates the level to which the upper edges of the book are to be cut, is flush with the cheek of the press. The book having been secured in the press, the plough is gently drawn backwards and forwards; the screw of the plough being slightly turned each time, that it is thrust from the workman; until the knife has cut through the whole thickness of the edges. The head having thus been cut, the book is taken out of the press, and the tail is then cut in a similar manner.

In cutting the fore edge, the projection of the boards is first marked upon the protruding edges of the first and last sections, and a couple of trindles, flat pieces of steel in the shape of an elongated $U$, about $I_{2} \frac{1}{2}$ inches wide, and 4 inches long, with a slot extending nearly their entire length, are then placed between the boards and the back of the book. This is done by holding the book, with its fore edge uppermost, so that the boards fall back from it, and by inserting the trindles in such a manner, that the slips at the head and tail of the book pass through the slots of the trindles. The back of the book is next forced perfectly flat, upon the cheek of the press; and a piece of string having been tied round the sections to keep them in position, the trindles are removed. Two cutting boards, or wooden rules, are now placed on either side of the book; one of which acts as the runner, the other as the cut-against. The runner having been placed 
at the level, to which the fore edge is to be cut, that is, at the projection of the boards, less the height of the squares; the book is lowered into the press, with the head towards the workman, until the runner is flush with one cheek of the press; and the cut-against is above the other cheek, by the height of the squares. If the book has been placed with accuracy in the press, it will now be perfectly square: in which case, it is to be properly screwed up in the press, and the fore edge ploughed in the same manner, as were the other edges. When the book is taken out of the press, and the string removed, the back will resume its original form.

The method of cutting a book in boards, which I have here described, is neither that, which was practised by English workmen at the early part of this century, nor that, which is employed at the present day by the Parisian bookbinders. The English workman squared the back, and fore, edges of his boards, and when he had laced them to the book, ploughed and squared the head and tail edges of the book and boards together; ploughing, lastly, the fore edge of the book. The Parisian binder, having squared the back edge of his boards, and having laced them to the book, cuts the edges of the volume, before he squares the boards.

Fine and rare books, the edges of which have already been cut, should not, as a rule, be recut : but their edges should be left, and gilt, as the phrase is, in the rough. The edges of a new and 


\section{The Craft of Binding}

uncut book, which is to be finely bound for the first time, should be completely cut : but a portion of the rough edge should be preserved, in proof of the discretion with which the cutting has been done. A broad margin has been said to be the glory of a book: but in recent years, the craze for wide margin has been carried to a degree of absurdity, especially in large-paper editions ; in so much, that it becomes necessary to qualify this assertion, and to say, that the glory of a book consists, not in an unduly broad, but in a finely proportioned, margin. In how many instances of recent 'éditions de luxe,' if the binder could but have a sense and knowledge of proportion, might not the plough be used with a liberty, which would be terrible to the prejudices of the collector, but consoling to the finer sense of the artist?

Decoration of THE EDGEs.-After the book has been cut, the decoration of the edges is next to be considered. Without doubt, the most elegant of decorated edges, and the one most proper to a book, which is intended to be elaborately tooled in gold, is a gilt edge. A method of gilding book-edges does not materially differ from that employed by the ordinary gilder. The boards having been thrown back, the book is placed in the press, with the head, or tail, edge level with the cheeks. The book is then screwed up in the press: and the edge is scraped, until it is perfectly smooth; care being taken, that its whole surface is equally worked. 


\section{$32 \quad$ Bookbinding}

The edge is next painted with a mixture of blacklead, red chalk, and water; this surface is dried, polished with a brush, and freely coated with glaire; and the gold-leaf is, then, applied, while the glaire is still wet. Glaire, which, from this time, becomes an important material of the bookbinder's craft, consists in the white of eggs, well beaten up, and strained. When the gilding has become thoroughly dry, it is burnished with an agate burnisher. If the edge is intended to be bright, it is, first, rubbed over with a waxed cloth; if dull gilt, a piece of thin, tough paper is laid upon the gilding, and the burnisher worked over it. After the head and tail edges have been gilded in this manner, the fore edge is similarly treated; the back having first been brought to a flat surface, and consequently the fore edge, as in the preparation for the cutting. The beauty of a gilded edge consists far more in the colour of the gold, than in that metallic solidity, which modern binders give to their work. The gold employed by the early Italians, in the decoration of their books, is of that silvery kind, which shows to admiration on the frames of their pictures, and other gilded work.

Gilt edges are found accompanying the earliest gold-tooled bindings; but these early examples are generally ' gauffered,' or tooled, by a method, which does not greatly differ from that of the blind tooling employed in the decoration of the boards, and which I shall describe in its place. The edges of 


\section{The Craft of Binding}

the books bound for Grolier, are commonly plain gilt, a trait which accords with the severity of their design, and which may be thought to distinguish them, from the earlier Venetian bindings, the edges of which are generally gauffered with the ropepattern : while the Lyonnese bindings, executed at the close of the sixteenth century, often have their edges gauffered with elaborate patterns, outlined in studded points. Of this kind of decoration, some admirable examples may be seen in the Victoria and Albert Museum. Already, in the second half of the sixteenth century, we find colour used upon gilt edges, in addition to the gauffering. The Germans especially excelled in this kind of florid ornamentation; and with that want of power to appreciate the charm of simplicity and unity, which characterises their art, they further attempted to portray both figures, and scenes, by this method; as on a copy of an Auslegung des Evangelii Matthaei, Leipzig, I575, in the same collection [230-'66.], on the edges of which a Last Judgement is gauffered, and painted, upon a gilt background. In the succeeding century, the same method of decoration is found employed, but with far greater reticence, upon some of the bindings ascribed to Le Gascon: but of these, and other examples, more in their place.

When a binding is not intended to be elaborately tooled, a coloured edge may be used with effect. Some powdered colour ground up with paste and a little oil, or glaire and oil, is applied to the edges 


\section{$34 \quad$ Bookbinding}

with a brush, the book having been slightly fanned out, right and left. The Italians commonly employed a yellow resembling Roman ochre, indigo and other blues, which occasionally approach to greens, with very decorative results, especially with their vellum bindings. The edges of a Petrarch, Venice, I532, in the collection of Mr. C. Fairfax Murray, are coloured blue, on which an enrichment, of the kind known as the rope-pattern, is gauffered in gold. The edges of the copy of Joannes Grammaticus, In Aristotelem, figured in Mr. Quaritch's Facsimiles of Bindings, Nos. 8 and 9, are ornamented with a Greek fret, in red and blue. But this is, properly speaking, a painted edge, of which many very elaborate examples are to be found, done in water-colours, which tended to the nature of a stain. In the possession of a well-known English collector, there was recently a remarkable Italian library, which formerly belonged to Odorico Pillone, of Casteldardo, in the Venetian State. It consists in one hundred and seventy volumes, for the most part folios, dating from the end of the fifteenth, and the first half of the sixteenth, century, and bound, for the most part, in dark pig-skin, with brass bosses and clasps. Of these books, more than one hundred and forty are remarkable for having their edges painted ; and the boards of some twenty of them are enriched by designs drawn with the pen, and washed in with Indian ink, by Cesare Vecellio, the nephew of Titian. The designs on the 


\section{The Craft of Binding 35}

fore edges of the books are chiefly composed of single figures, drawn and coloured in a large and decorative manner : thus the figures of Dante, and Galen, appear on their several works; while St. Jerome is variously depicted, sometimes as a cardinal, and sometimes as a hermit, on the edges of the portly edition of his works, printed by Froben at Basle [Catalogue of the Library of Thomas Brooke, London, I89r, vol. ii. p. 662.].

Books, whose fore edges were painted in this manner, were not intended to be placed on shelves, after our modern fashion. It is a common thing to find the title of a fifteenth century book, written along its fore edge, in a contemporary hand; and this is sometimes found, when the name of the author is stamped upon the upper board, which was the common practice, during the first half of the sixteenth century. The reason of this lies in the practice of those times, to place books upon their boards, one upon another in the shelves, with their fore edges exposed. The chained manuscripts in the Laurentian Library at Florence are still to be seen preserved in this manner: and the same arrangement may be noticed in a small picture in the National Gallery, an interior ascribed to the younger Steenwyck [No. II32.] ; although some of the books are here placed, so as to expose the patterns on their boards. M. Henri Bouchot, in his little work, entitled Le Livre, has reproduced from a manuscript, a representation of a library, 


\section{$36 \quad$ Bookbinding}

on which the books are placed after this latter fashion, upon sloping desks, not unlike those in the Library at Sicna. This custom of placing books so as to expose either their fore edge, or their boards, accounts for the plain backs of the earliest goldtooled bindings, for the occurrence of the name of the book upon their upper boards, and for the richness of their fore edges. The circumstances, which occasioned these peculiarities in early bindings, occasioned, also, the use of clasps, or strings : for the art of forwarding was at that time so imperfectly understood, that some means or other was necessary, in order to make the boards lie parallel to one another, and to prevent the volume from gaping, at the fore edge. I do not speak of books printed upon vellum, for which a clasp or string was requisite to prevent the skins from curling; but of books printed upon paper, in which the impression of the type was often greater than its own thickness. A series of books, then, in which the breadth of the back was less than that of the fore edge, if placed one upon another, on a shelf, with their backs exposed, would have a tendency to fall forward; whence the habit of reversely placing them, so that they inclined towards the wall, or back of the case. The fashion of lettering the backs of books appears to have been first introduced by Italian binders, during the second quarter of the sixteenth century; at which time the use of strings for smaller volumes began to be discontinued: but 


\section{The Craft of Binding}

this fashion of lettering did not become universal, for nearly a century. In England, especially, the art of forwarding was slowly perfected: and we find, as late as the year 1612 , on the tomb of Sir Thomas Bodley, in the chapel of Merton College, at Oxford, a representation of books furnished with clasps, and placed upright upon shelves, with the fore edge exposed.

But to return to my subject of painted bookedges : a late, but very remarkable, example of a painted edge may be seen in the Victoria and Albert Museum, on a copy of the New Testament, with the Psalms, in Dutch, I594 [85-'66.]. The book possesses an embroidered binding ; and the edge, which is of exquisite workmanship, is painted with a multitude of figures, probably the work of a Dutch artist. In England, where the art has not been neglected, Edwards, a binder of Halifax, in the early part of the last century gained a certain repute for his book-edges, which he decorated with landscapes possessing much of the charm, which the English painters in water-colours, of that time, gave to their work.

Of the various methods of marbling, and sprinkling the edges of a book, I must refrain from speaking, in this place. But I may add, that some charming effects of colour were obtained in France at the end of the seventeenth, and the beginning of the eighteenth century, by a method, which is known as marbling under the gold. The edges of 


\section{$38 \quad$ Bookbinding}

the book are fanned out, right and left, and marbled; and the book is then closed, and gilded in the ordinary way; so that the marbling only appears beneath the gold, when the book is opened. Painted edges have, also, been executed under gold, in the same manner.

HeAD-BAnding.-We are now come to the consideration of the head-bands, which appear at the head and tail of a book, and over which the covering of the back is trimmed and finished. This embellishment, for it is now little more, was originally one of the bands upon which the book was sewn, taking the place, and fulfilling the functions, of the kettle-stitch. The use of this method, which appears to have belonged entirely to the age of manuscripts, gave strength to a binding; but it was discarded, because it prevented the edges of the book from being afterwards cut.

In theory, head-banding is a very simple operation; but in practice it requires an exceedingly nice and skilful hand. It is, in reality, a twist of two or three, silken or linen, threads round a band, oblong or circular in section. If oblong, these bands are made by pasting and pressing together several thicknesses of vellum, which, when dry, are cut into strips; if round, catgut is commonly used for them : but either sort must be of such a size that, when covered, they are somewhat less in height, than the squares of the book, for which they are intended. The band is cut to a length, which is greater either 


\section{The Craft of Binding}

way, than the width of the back, by half an inch; and the book is placed in the lying-press with the head, or tail, which is to be head-banded, raised to a convenient height. If the head-band is to be worked in two colours, white and green, a green and a white thread are to be neatly fastened together at one end, and one of them, which must be much longer than the other, and which we will take to be the white, threaded through a needle. This is twice passed through the back of the book, in the centre of the second section, beneath the nearest band on which the book is sewn, so as to leave a loop: the head-band is then placed in this loop, and held fast by the thread being drawn tight. The green thread is now twisted round the white once, and round the band twice; after which the white is to be twisted round the green, and round the band twice; this process being repeated until the whole of the band is covered: but the needle must be passed through the back, at every third, or fourth, section, in order to secure the head-band. When the head-band is covered, the twist is fastened off by passing the needle through the back twice, and twisting the green thread round the white, under the vellum, after which they are securely tied together. Parti-coloured head-bands of this nature date from the beginning of the sixteenth century; and an early example, worked in blue silk, and silver thread, is to be seen on a copy, preserved in the British Museum, of the Aldine Petrarch, printed in 


\section{$40 \quad$ Bookbinding}

I50I, which I shall describe in its place. Headbands in one colour, are worked in a similar fashion; while those in three colours are worked, of course, with three threads. In these days of commerce, head-bands are rarely worked by hand: indeed, the number of skilled head-banders, in London, at the present time, is very small. Most bookbinders use machine-made head-bands: these can be purchased of any size, or colour, at a moderate price, and are stuck on.

The head-band is now set with glue: and if the bands are to show upon the back, they are first moistened with paste, and worked with a foldingstick, or some such blunt instrument, until they are smooth and regular. If however the bands are not intended to show, after the book is covered, they are rubbed as flat as possible, and two or more thicknesses of leather are fitted and pasted between them, until the whole of the back presents one level surface. It is at this stage, that the modern binder forms his hollow back, and adds his false bands. A hollow back is made by pasting a piece of paper, commonly brown paper, of the height of the book, upon the back. The paper projecting beyond the one edge of the back, is folded over, and cut to the width of the back; after which, the paper, projecting beyond the other edge, is treated in a similar fashion. The two pieces of paper, thus folded over, are then pasted upon one another, so as to leave a hollow space, when the book is open, 


\section{The Craft of Binding}

between them and that portion of the paper, which is pasted upon the back. The false bands are usually made of several thicknesses of leather, pasted together, and cut into strips : and they ordinarily have no relation whatever to the real bands on which the sections are sewn.

CoverING.-The book is now ready for covering; and for this purpose, nearly every kind of skin, and embroidered, or woven, fabric has been employed, which could well be used. In the middle ages, woven fabrics were largely employed for this purpose: but the use of skins in covering books, appears to have existed from the earliest times. The bindings of forrell, 'the rough undressed skin of the beast,' were already, at the end of the fifteenth century, superseded by those of finished leather; the native leathers being naturally found in use, in a country, before those of foreign manufacture. Thus, among the books in the Old Royal Collection, few are to be found covered in morocco, before the time of James I. ; calf, vellum, sheep, doe and pigskin, being commonly found on English books, of the sixteenth century. The books of Iceland are covered in seal-skin ; and there is a copy of Governor Phillip's Voyage to Botany Bay, London, I789 [C. 47. i. Io], in the British Museum, which is bound in kangaroo-skin. Dibdin alludes to a copy of the Historical Works of Charles James Fox, which Jeffrey, the bookseller, had covered in fox-skin: and the same writer hints at a book, "which the 


\section{$42 \quad$ Bookbinding}

renowned Dr. Askew caused to be bound in human skin.'

But, without doubt, no coloured leather is comparable to morocco, either for beauty, or for use. It was formerly brought from the Levant, Turkey and the Barbary coast, where the leather was made from goat-skins, tanned with sumach, and finished in black, or in various colours: and it is this leather, which we still admire, both for its beauty, and its durability, on the fine bindings of the sixteenth and seventeenth centuries. It was peculiarly clear in colour, fine in grain, and soft, yet firm, in substance. The goat-skins are now brought to the London market, in a rough state; and the finest leathers are prepared from them, in Paris: but straight-grained morocco, which was much in use at the beginning of the present century, still continues to be a peculiarity of English manufacture. The grain of morocco, both cross and straight, which is so much affected by contemporary binders, without reference to the size of the book, or the nature of the design to be worked on it, is artificially given to the leather by a paumelle, or toothed wooden instrument. Beside the morocco leathers, which are dyed with a single colour, there are other kinds, which are variously mottled, marbled and otherwise decorated. The grain of the marbled morocco, which covers some of the books of Maiolus, is filled in with gold: and that used in covering some of the more simply bound 


\section{The Craft of Binding}

books of De Thou, is ornamented with patterns of an Eastern character; as on his copy of Phaedrus, Paris, I6I7 [C. I9. c. 2I], in the British Museum. There is a kind of coloured morocco, which is still made at Valencia, in Spain : it was first brought to this country by Sir William Stirling-Maxwell, and has been frequently used by Mr. Roger de Coverly, the binder. It is a thin leather, with a highly glazed surface, mottled with a great variety of bright colours, which have a curious effect, owing to dried leaves and flowers having been pressed upon the leather, while the colouring was still wet; a peculiarity, which is not apparent, until the leather has been closely examined.

Mr. de Coverly has, also, coloured some of his books in calf, in a manner very similar to that, in which this Spanish morocco is coloured. Marbled, mottled and sprinkled calf was much in use during the last century: and this mode of decoration has continued to the present day. It is produced by the application of various chemicals, after the book is covered : but the calf of modern commerce is so liable to crack at the joints, that it should not be used for fine bindings. The calf, however, which is found on books of the sixteenth and seventeenth centuries, is often of great beauty in colour and texture ; and in some cases, seems to possess extraordinary durability : indeed, it is sometimes difficult to decide, whether the leather, which is used on some of the earlier bindings, is calf, or morocco. 


\section{$44 \quad$ Bookbinding}

There is the same objection to the use of Russian leather, as to the use of calf : namely, its tendency to crack at the joints. This leather, as its name implies, was originally obtained from Russia, where it was made from the hides of young cattle; it is now made in other countries, the best sort coming from Austria. Genuine Russian leather is tanned in willow bark; and its peculiar odour is due to an oil, obtained from the bark of the birch tree, with which the leather is dressed, in the process of finishing. This leather was introduced into England at the end of the last century; and was much used by Roger Payne. Modern pig-skin, on the contrary, appears to be of a very durable nature, and especially lends itself to be finished in blind tooling; it has not that pleasing colour, and texture, which distinguishes the skins used by the binders of the sixteenth century. Vellum is the most durable of all skins : but the Roman vellum, which is prepared for writing purposes, from lamb-skins, in the Campagna, is not so good for binding, as the thicker, English vellum, which is made from calf-skins. Of the inferior leathers, there is little occasion, here, to speak: imitations of morocco are now made from sheep and split calf; and roan is sheep-skin tanned in sumach, and coloured and dressed in imitation of morocco, except that it is finished with a smooth surface. Sheep itself has been entirely superseded by cloth, for cheap bindings. The fashion of binding books in cloth was, according to 


\section{The Craft of Binding}

a writer in Notes and Queries, the invention of 'Mr. R. E. Lawson, of Stanhope Street, Blackfriars, formerly in the employ of Mr. Charles Sully, and the first book bound in cloth was a manuscript volume of music, which was subsequently purchased by Mr. Alfred Herbert, the marine artist. On this volume being shown to the late Mr. Pickering, who was at that time, I823, printing a diamond edition of the Classics, he thought the material would be admirably adapted for the covers of the work. The cloth was purchased at the corner of Wilderness Row, St. John Street, and five hundred copies of the diamond Classics were covered by Mr. Lawson with glue.' Cloth is a perishable material, admirably adapted for covering books, which are intended for ordinary use, and not afterwards to be put into fine bindings : but it is not a material upon which a design of any value should be impressed.

Morocco, then, is the only coloured leather in general use, against which no serious objection can be urged, by either the binder, or gilder : and I shall, therefore, confine my remarks chiefly to the covering and finishing of books, in that material. Each kind of leather, however, as well as silk, velvet and other woven, or embroidered, fabric, requires to be variously worked, according to its peculiar nature. A piece of leather is firstly to be cut, with a sharp knife, from a skin of morocco, as much larger than the book, every way, as may be necessary to cover the edges and squares of the boards. 


\section{$46 \quad$ Bookbinding}

This, having been placed upon some perfectly smooth surface, such as that of a lithographic stone, is next to be pared with the paring knife. The knife, which is used by the French binders for this purpose, is not unlike a broad chisel, having a rounded, instead of a straight, cutting edge. It is held in the right hand; and the leather is pared, or thinned, on the flesh-side; care being taken to reduce every part of its surface equally, but not to a degree, which would destroy the strength of the morocco. Those parts of the leather, which are to be turned over the edges and squares of the boards, are, however, to be pared more thinly than the rest; especially at the head and tail of the back, where the leather will be folded upon itself. This done, the morocco is to be well wetted; and its grain either raised, or reduced, according to the intention of the binder. If a book is to be finished with little, or no, gilt tooling, a coarsely grained leather may be used with effect; but very delicate and elaborate tools should not be worked upon such a surface. To do so is to ignore that sense of propriety, upon which beauty of workmanship in no slight measure depends. The grain of a leather should, in brief, be chosen in regard both to the size of the book, and to the degree of elaboration, with which it is intended to be finished. If the grain is to be raised, this may be done by curling the leather with the hand, but if it is to be reduced, the leather must be well rolled with a wooden 


\section{The Craft of Binding}

rolling-pin, and the flesh-side having been pasted with thin paste, it is hung up to dry.

After the leather has dried, it is to be well pasted; and the book is to be accurately laid in its place, upon it. That done, the leather is first to be drawn over the back; care being taken to give a proper form to the bands : after which, the leather is laid down upon the boards; and what is superfluous at their four angles cut away, that their edges and squares may next be covered. This operation requires great nicety, especially in the manipulation of the leather at the head-bands. The mitres, at the inner angles of the boards, are made by folding the returns of the leather, one upon another; and cutting through both thicknesses of leather with a sharp knife, at an angle of 45 degrees to either edge. If the projection of the bands be very great, the difficulty in covering a book is largely increased: and it is easier to lay down a smooth, than a highly grained, leather, as the texture of the latter is apt to be damaged by an unskilful hand. A well-covered book will have its edges sharp, its angles and mitres accurate; and the leather equally drawn over the boards, andwell formed at the bands, and head-bands.

Not only morocco, but vellum and other leathers, should be laid down with paste. When vellum is used, the boards should first be lined with white paper; or the vellum itself lined, which was the custom of the early binders, to prevent the skin from contracting the boards. 


\section{$48 \quad$ Bookbinding}

If the book have a vellum end-paper, or a morocco joint, the outer end-paper is now to be removed, and the vellum leaf, or the joint laid down upon either board, the latter being mitred at its junction with the leather covering the squares of the boards. The panel, which is thus formed on the inner side of either board, is next to be filled in with paper or silk, according to the intention of the binder: but the sides and angles of the panel are first to be squared and trimmed; and the paper or silk should be equal in its thickness to that of the surrounding leather. A method of decoration, dating from the first half of the sixteenth century, and apparently of Arabic origin, consists in lining this panel with leather, commonly of the same kind as that which covers the boards, but of a different colour : this, in many examples, is afterwards tooled with a richness equal to, or even greater, than that of the exterior of the volume. A doublure, or interior decoration of this kind, occurs in the copy of Petrarch, Venice, I532, in the collection of Mr. Fairfax Murray, already mentioned, and is perhaps, the earliest, European example extant of this sort of enrichment. It is tooled in silver upon brown leather, while the outside of the book is decorated with a design, similar to that of the doublure, in gold, but with the letters B. S., substituted for the figured tools in the centre of either compartment: this binding appears to have been executed shortly after the publication of the book. 


\section{The Craft of Binding}

FinIsHing.-The book has now passed through the whole of those operations, which are included in the term 'forwarding ': and the ornamentation, or finishing, of the volume, alone remains to be done; either by the process of tooling, stamping, painting, or inlaying; or by some combination of these methods. The processes of tooling and stamping, with which we are now chiefly concerned, do not differ from one another in kind, but in degree. Both tools and stamps are commonly cut in brass, and bear their figure or pattern in relief, whereby an impression is produced of a similar nature to that of a wood block, or the ornamental types used in printing. Tools and stamps differ from one another in the manner in which they are worked, either by hand, or in a press. A tooled binding is a binding finished by hand: a stamped binding is a binding finished in a press. A tool, in order to produce a solid and sharp impression, must be of such a size, that the finisher is able to work it with ease; and of such a nature, that he may at once see every part of its contour, in order to make a true impression. If the tool be too large, the force necessary to work it will prevent him from equally impressing every part of it on the leather; and his work will consequently not be solid : if the contour of the tool be too intricate, he will be apt, in gilding, to double its impression; and so his work will not be sharp. But the more skilful the finisher, the larger and more intricate a tool will he be able to work. 
Figured tools, which are commonly mounted in wooden handles, like a carpenter's chisel, should not be larger or more complex than those reproduced in Fig. 3, on p. 224, if they are intended to be used for elaborate work. A tool engraved with a curve, or a segment of a circle, like A in the same figure, is called a gouge. The parallel lines of a border are usually engraved upon wheels of various sizes, which are known as fillets, if they bear more than one line : other wheels engraved with some figured ornament, which is repeated at each revolution, are called rolls. A pallet is a figured tool, with a curved face, used in finishing the backs of books by tradebinders, some of whom, also, use a type-holder, in lettering the title: but such devices for economising labour should not enter into the art of fine binding. The back of a book should be finished and lettered by means of separate tools, in the same manner as the boards. The other implements and materials, necessary to finish a book, are: polishing-irons, sponges, glaire, vinegar, gold-leaf, a gold-cushion, cotton-wool, a gold-rag for removing the surplus gold, india-rubber for cleaning off what is left by the gold-rag, and a finishing stove. The old binders used, for this purpose, a brazier of live charcoal, having a perforated iron plate placed upon the top ; now various gas and oil stoves have been invented, by which the heat can be better regulated. In finishing the boards, the book is laid upon a bench or table; but in tooling the back, it is held rigid 


\section{The Craft of Binding $5 \mathrm{I}$}

in a finishing-press, which is similar in principle to a lying-press, but of a lighter sort, having the outer angles of the cheeks bevelled, to allow of greater freedom in working the tools.

The binder having designed the pattern, with which he intends to ornament his book, proceeds to work out the same on a sheet of thin, tough paper, precisely as he would have it appear upon the finished leather, in regard both to its size, and to every other particular. This he does, by blackening the actual gouges, fillets and other tools, which he wishes to employ in the execution of the work, in the smoke of a candle-flame, and by making impressions of them, in their proper places, on the paper. When the pattern is completed, it is accurately placed upon the board, which it is to decorate, being secured at the corners by a little paste, and the pattern tooled, through the paper, on the leather. A skilful finisher will not need this elaborate preparation, but will content himself by setting out the chief points of his design upon the leather, with the aid of a pair of compasses. The paper is now removed, and the leather washed or damped with vinegar, which should be rubbed equally into the leather, by means of a brush. The blind impressions made by the tools, through the paper, are next to be twice pencilled in with glaire; and when they are dry, rubbed very slightly with a piece of oiled cotton-wool. A leaf of gold having been spread upon the gold-cushion, and cut into pieces 


\section{2}

\section{Bookbinding}

of the size and shape of the various tools; these pieces of the leaf are next taken up, one by one, with a pad of cotton-wool slightly greased, and gently, but firmly, laid upon the impressions, which the tools have left on the leather. While the impressions are being covered with gold-leaf, the tools are to be heated on the finishing stove, to that degree of heat, at which a drop of water, applied to any one of them, does not hiss, but dries instantly. In this condition, the tools are to be successively worked in the various blind impressions, already made by them on the leather, in working the pattern through the paper: but care must be taken, that each tool is exactly placed in its former impression, otherwise the contours of the tools will become blurred, or doubled. The whole of the impressions having been tooled in this manner, the superfluous gold is removed with the gold-rag; and any defective parts of the work must be re-pencilled with glaire, and re-tooled, until the gilding of the whole is equally solid. Some Parisian workmen repeat this operation several times, in order to obtain that solidity, for which their gilding is conspicuous: but the effect is more often correct and mechanical, than pleasing. Not, only, is an extraordinary dexterity and steadiness of hand necessary to execute this kind of gold tooling; but, also, great experience as to the precise temperature, and skill in working all the tools at an equal temperature; for different leathers require different degrees 


\section{The Craft of Binding 53}

of heat, and that which would burn one leather would not make a sharp impression upon another. In short, the tool must be hot enough to make the gold adhere, but sufficiently temperate to produce a bright impression. The back is tooled much in the same way as the boards; but the inside of a book is generally finished before the outside.

I have, thus, briefly described the method, which is usually employed by the modern bookbinder in gilding a book bound in morocco; but there are many variations upon it, which may be followed. The early Venetian binders often finished a book with silver-leaf which they apparently worked in the same way as the gold-leaf. Silk, velvet and paper, are finished with dried and pulverised glaire, to which have been added certain gums. If a book is to be finished in blind, that is, without gilding, the leather has merely to be damped and the tools worked at such a temperature as shall produce a sharp impression, or, if necessary, produce a darkened impression, by slightly charring the leather. Stamps were formerly worked hot, in an arming-press, so called because coats of arms were commonly finished on the sides of books in that way: but during recent years, many more elaborate kinds of presses have been invented, by which stamps and blocks can be accurately worked with great expedition.

Many, also, are the methods by which inlaid, or mosaic work, as it is sometimes called, may be executed: perhaps the best way is to place the 


\section{$54 \quad$ Bookbinding}

leather, which is to be inlaid, upon the ground, and cut through both their thicknesses at once with a sharp knife. The lower leather is then removed, and replaced by the upper one: and the joint covered by a line, or other ornament, in gold. Another method is to apply the various coloured leathers, by paring them until they are exceedingly thin, and pasting them upon the ground.

Such are the chief methods by which modern European books have been gilded, or otherwise ornamented : but any account of the various canons of taste, which have determined the figures of the tools, and the principles of their combination and repetition, would be, in effect, but a history of the work of those binders, who have practised the craft since the end of the fifteenth century. This, I shall now attempt to indicate by a short history of those periods of Italian, French, and English binding, when the art was at its finest: and afterwards I shall endeavour to deduce, from the productions of those times, certain principles of taste and composition, which would seem constant in this art. 


\section{CHAPTER II}

\section{EARLY ITALIAN BINDINGS}

THE art of finishing books in gold tooling came into vogue with that general use, which followed the discovery, of printing, towards the close of the fifteenth century. Within the space of a few years, scarcely the quarter of a century, both of these arts had reached, in Italy, a degree of excellence in fineness and beauty of design, to which they have not a second time attained: but this sudden accomplishment does not appear extraordinary in the age, which realised the perfection of Art, in the masterpieces of Raphael, Leonardo and Michelangelo. In that culmination of taste and manners, it was not possible, that the printing and binding of books, upon which Literature in no small measure depends, should remain among the mechanical trades: and yet, once informed by those qualities of design, from which the fineness of an art proceeds, the period of this accomplishment was as brief, as its rise had been sudden. The criticism, which Michelangelo passed upon a medal by Il Grechetto ; remarking, that the hour for the death of Art had arrived, since it was not possible for a better work, in its kind, to be seen; was true of the whole series and 


\section{$56 \quad$ Bookbinding}

condition of the decorative arts at that time. In other directions, they might hereafter reach an equal excellence; but it was not possible to carry the manner, in which they were then practised, to greater perfection: and the justness of this criticism is evident in the effect, which the influence of Michelangelo himself produced upon the masters, who succeeded him, and who worked according to the tradition of his manner. From the moment, in which he began to exercise his fascination over the world, the history of the decorative arts is that of their gradual decadence; a decadence, which has, in the art of bookbinding, continued to the present time, despite the felicity of the courtly styles prevalent in France, for more than two centuries. And in the binder's art, as in the art of printing, this gradual decadence was accompanied by a gradual approach towards a greater perfection of workmanship, the one diminishing as the other increased; until a technical excellence was reached by certain French binders, during the last century, beyond which it would seem impossible to proceed. Such are the chief characteristics of the history, which I am about to touch upon: nor are they common only to the arts of printing and bookbinding.

The origin of the art of gold tooling in Italy, is very obscure: the method, which seems first to have been employed, at Venice, about the time that Aldus Manutius established his press in that city, superseded an earlier use of gold in the decoration 


\section{Early Italian Bindings}

of books. The art was certainly brought from the East; and is said to have been employed with effect in Syria, as early as the thirteenth century. Upon the fall of Constantinople, in 1453, a great number of manuscripts were carried into Italy, from which, according to some authorities, this manner of finishing books was derived: but it may be urged with equal probability, that the art was one of the many Oriental inventions, acquired by the Venetians, in their traffic with the Levant. The bindings executed in Venice, and certain other parts of Italy, during the second half of the fifteenth century, are commonly of brown leather, tooled in blind, on either cover, with a border consisting in one, or more, members of interlaced work between marginal lines, forming a panel, which is enriched by a knot of work similar to that of the border, and contained within a circle. The interstices of the interlaced work are usually filled with minute roundels: and the ornament within the panel is occasionally repeated. The interlaced, or reticulated, work is usually of a very intricate nature, and is formed by a narrow fillet, decorated with a series of oblique lines, in imitation of the twist of a rope; from which it has been called the rope, or cable, pattern. The back is usually ornamented with reticular lines, in blind tooling, between the bands, which are double; the boards are of wood; and the edges of the book are left plain. It is a peculiarity of these bindings, that in addition to 


\section{$5^{8} \quad$ Bookbinding}

the two clasps on the fore edge, the larger volumes have two others, upon the head and tail edges: while angle-pieces of wrought brass to protect the corners of the boards, and bosses of the same metal, are occasionally added. Many manuscripts in the British Museum remain bound in this manner; of which a very beautiful codex of the De Civitate $D e i$, by St. Augustine [Add. Ms. 15,246.], may be especially mentioned : the clasps are lost; but the book retains its original back. Some examples show the addition of a figured tool, such as that of the flies, on a manuscript of the Histories of Sallust, dated 1477 [Burney MS. 245.]. It is on bindings of this nature, that the use of gold, in the decoration of Italian books, is first to be found. In certain instances, the gold on the little roundels, filling the interstices of the interlaced work, was applied by some process, which left the surface of the gilding dull; as on the binding of a manuscript of the Contra Gentes, by Athanasius of Alexandria, reproduced by Mr. Quaritch among his facsimiles [No. 85.]. Another, though a less fine, example may be found among the Additional Manuscripts in the British Museum [Add. MS. 25,088.] ; covering an epitome in Latin, of Priscian's Commentaries. In some instances, the roundels are copper-gilt ; as upon the binding of another manuscript of the $D e$ Civitate Dei [Add. MS. I4,783.], which possesses great beauty of design, and differs somewhat from the more common pattern. But the use of gold, if 


\section{Early Italian Bindings}

at first confined to the gilding of the roundels, was soon applied to other parts of the tooling. Upon the manuscript of a treatise by Lucius Fenestella, De Magistratibus Romanorum, etc., [Egerton MS. 26I7.], a lozenge-shaped centre-piece, enclosing a dragon's head, is wholly gilt : as likewise is a knot of rope-work, upon a little codex of Martial, [Add. MS. I2,004.]; the edges of which are gilt and gauffered. These Italian bindings afford a remarkable contrast to the contemporary stamped bindings of Germany and England, in which the ornament, often very admirable in itself, and presenting not only figures and symbols, but also scenes and incidents, of great significance to the antiquary, was invented and refined upon for its own sake. In the Italian bindings, on the contrary, a few simple elements are combined and arranged in repetition, to produce a certain total impression, to which the details of the ornament are always subservient: and in this way a certain fine and simple richness of effect is obtained, which must always the rather commend itself to an ordered taste. These bindings, to which the gold was, probably, applied by means of a mordant, are also found, but more rarely, upon printed books, as well as upon manuscripts. A copy of a treatise by Leonicenus Omnibonus, De Octo Partibus Orationis, Venice, I474, preserved in the British Museum [IA. 29895.], is bound in this manner, with copper-gilt roundels.

The introduction of gold tooling into Italy has 
been attributed, without any authority, to Aldus Manutius, apparently from the fact that his name is the first which occurs in connection with the art : but it is more probable, that the method, first practised in Venice, was brought into common use by its employment upon the books of his impression. Although he first set up his press, at Venice, in I494; he did not commence printing his editions of the Latin classics, with italic types, in eights, until I5Or, in which year he published the Virgil. The form and character both of the book, and of the type, were new : and their success was unprecedented. It is probable, that upon the bindings of these books gold tooling was first generally employed. A copy of the Statius, printed by Aldus in 1502, and retaining its original binding, is in my own possession. The boards, which are of wood, are covered with brown leather: either cover is decorated by a figured border in blind, of arabesques ending in dolphins, formed by the repetition of a single tool : and in the centre of the panel, contained by this border, is a knot of Arabic work in gold tooling. The back, which has double bands, is decorated in the manner of the earlier manuscripts, which I have already described: the edges are gilt and gauffered with interlaced rope-work: and the book originally possessed two clasps upon the fore edge. It is remarkable, that, although the rope-pattern was disused in the decoration of the boards before the close of the fifteenth century, it continued to 


\section{Early Italian Bindings}

be commonly used in the gauffering of the edges, during the first three decades of the succeeding century ; and is to be found until a comparatively recent period. The question remains, whether the dolphins, occurring in the border of this binding, were used in allusion to the Aldine mark of the Dolphin and the Anchor, which M. Gruel, repeating, perhaps, the assertion of MM. Marius-Michel, states to be found upon some bindings of Aldus. Such an example, I have not had the good fortune to see: but the British.Museum possesses a copy of the first volume of the Orations of Cicero, upon vellum, printed at the Aldine press in I5I9 [C. I6. g. 5.]; the mutilated binding of which is ornamented with a border of dolphins, similar to that upon the Statius, but executed with a tool of finer workmanship. The whole of the tooling upon this binding is executed in blind; the panel within the border being ornamented with little roundels, and knots of Arabic work: and the boards, which are no longer of wood, but of pasteboard, are covered with black morocco. In some examples, the name of the author is stamped upon the panel of the upper cover, as upon another mutilated binding in the Grenville Library, containing a Martial, I50I, with an Euripides in Latin, I507 [G. 963I.]. With the exception of the names of the authors, which are tooled in gold, the characteristics of this binding are similar to those of the earlier binding upon the Statius. 
The Museum possesses, also, a copy of the sonnets of Petrarch, printed by Aldus in I5OI, in its original binding of dark olive green morocco [C. 20. b.]. This copy being upon vellum, the binding is of more than ordinary cost and finish. The panels of the boards are ornamented by a series of knots and Aldine leaves, and surrounded by a double border, the one of figured, the other knotted, work: the whole of these ornaments being in gold tooling; while the back of the volume is richly tooled in blind. The edges of the boards, which are of wood, are grooved: and the head-band is curiously returned against the head and tail edges of the boards. Altogether, this is a binding of uncommon beauty and interest.

In the history of Aldus Manutius, little is more remarkable, than the eagerness with which his italic types were copied. Within a year of their publication, a counterfeit of them appeared at Lyons : and among the Italian printers, Filippo di Giunta of Florence early attempted their imitation. A copy of the Divina Commedia of Dante, printed by him with these types at Florence, in 1506 , is preserved in the British Museum [C. 65. f. 5.], in its original binding of black morocco. The back and edges of this book are plain: but either board is enriched by a figured border, the pattern of which is founded upon a series of circles; and both the panel within, and margin without, this border are studded with 


\section{Early Italian Bindings $6_{3}$}

leaves and knots of Arabic work; the whole being in blind tooling. The Museum, also, possesses a copy on vellum, of the Commentaries of Caesar published by the same printer at Florence, in $\mathrm{I}_{5} \mathrm{I} 4$ [C. I9. f. I2.]; the binding of which is figured in the frontispiece, Plate I. It is of green morocco, and both boards are elaborately tooled in gold; the marginal lines in which the angle-pieces are set, alone being in blind. The gold-tooled work on this binding is principally composed of the running pattern, founded upon a series of circles, which occurs upon the binding of the Dante. The edges of the book are gilt, and gauffered with a band of lozenge-shaped ornament relieving a panel, formed by a reticulated border. It has been suggested with great probability, that Aldus, in common with other early printers, had a binder's shop in connection with his press: and the recurrence of the same tool upon the bindings of Filippo di Giunta would seem to suggest that the Florentine printer also employed his own staff of binders. But conclusions of this kind are not to be drawn with any certainty. Among the Additional Manuscripts, is a Commission of Agostino Barbarigo, Doge of Venice, to Lorenzo Giustiniani, dated Ist April I498, and bound in brown morocco, elaborately tooled in gold [Add. Ms. 25,034.]. On this binding, which is undoubtedly of Venetian workmanship, and of the same date as the manuscript, both the knot of Arabic work, which occurs on the binding of the 


\section{$64 \quad$ Bookbinding}

Aldine Statius, and the running border on that of the Florentine Dante and Caesar, are used in combination with other tools. How then is the recurrence of these patterns to be explained ? It might, perhaps, be surmised, that, when Aldus first set up his press in Venice, he employed the gilders whom he found there, and allowed them to practise their art in their own manner, using the tools and patterns then in fashion, with the addition of certain others for his peculiar use. But even this conjecture is, perhaps, not to be corroborated by fact: since the figured tool of the dolphins, used upon the Aldine bindings of the Statius and the Cicero, is, also, to be found upon a Venetian binding of a manuscript poem, by Publius Faustus, in honour of Louis xII., preserved in the Bibliothèque Nationale, and reproduced among M. Henri Bouchot's Facsimiles of Bindings in that collection [Pl. XVIIr.]. As for Filippo di Giunta, it is probable, that he imitated the bindings, as well as the types, of Aldus: indeed, when we remember the relations of the Florentine printer with Venice, it is not unlikely that the bindings of his Dante, and Cacsar, may have been executed by Venetian workmen. In brief, to speak precisely of these early bindings, or to attribute them to this, or that, individual stationer, is not possible; but only to include in the term, the first Aldine style, the gilding executed by Venetian workmen with the tools, which characterise the original bindings of the books, printed by Aldus 


\section{Early Italian Bindings 65}

Manutius. ${ }^{1}$ These early gold-tooled bindings, which belong to the close of the fifteenth, and the first quarter of the sixteenth, century, have certain principal characteristics in common. In them, a richer and more splendid sense of decoration is produced by a few simple tools, than the invention of succeeding times was able to accomplish by far more elaborate means. But the art, which produced this felicitous effect, was essentially of a popular nature, in the sense in which the whole of the beautiful household art of Italy, at that time, was popular: and these bindings, fine as they are, lack that severe and scholarly restraint, which distinguishes the work of some of the later binders. The tools, moreover, employed in their production, were too large, and too heavy, to allow the gilding to be worked with the solidity, which has since come to be considered a sign of good workmanship : indeed, the forms of these tools are often precisely similar in character, to those of the ornaments used with the types of the early printers; from which they were imitated, without due regard to the new use, for which they were intended. And yet, as I say, on no other bindings is an equal

1 I should indicate in this place, the precise sense in which I have used the words, 'style' and 'manner.' I speak of bindings, as being executed in the same style, when the principal elements of their design, as well as the arrangement of these elements, are of the same kind. Such a style may be treated in various manners by various binders: thus certain bindings executed for Henry III. of France, and James I. of England, are both tooled in the style of the 'semis'; yet are treated in different manners. 


\section{Bookbinding}

sense of decoration to be found, as on these, and certain other Italian bindings of the same date. The freshness of the spirit in which they are worked, the simplicity of the means by which their effect is obtained, their distinguished taste, their beauty of form and colour, place them by themselves, unapproached among the greatest works of art, in their kind. It is much to be regretted, that these singularly beautiful bindings have not been more carefully preserved, and studied. The British Museum possesses a very fine collection of Aldine books : but, with the fewest exceptions, they have been rebound by their former owners. The original boards of the copy of the Orations of Cicero, were found beneath a modern covering of parchment.

The interlaced, Arabic, work was not only used by Aldus, in the knots and borders of his bindings, but also, in the decoration of the initial letters of the books themselves; as in those of the Hypnerotomachia, I499, and of the Aristotle, printed in I 495 . There is, in the Harleian Collection, a Venetian binding of a Virgil, which illustrates the Eastern origin of this interlaced work [Harl. MS. 3963.]. The border of this binding which was executed towards the end of the fifteenth century, is ornamented by a series of such knots; while the panel is decorated with a legend in Arabic, repeated at the centre and the angles, within a circle and quarter circles ; and it is evident, not only from the Arabic characters, but, also, from the manner of the other 


\section{Early Italian Bindings}

ornaments, that the design of this binding has been imitated from some Oriental original. The unmistakable influence of Eastern art upon Venetian binding is further shown in another method of decoration, directly copied from Persian, and other Oriental books. In this kind of binding, which was in vogue about the middle of the sixteenth century, the boards were commonly formed of some composition of paper, which was worked into sunk panels or compartments, and which was sometimes covered with leather. Among the books in the Old Royal Collection, now in the British Museum, is a copy of Girolamo Mascher's Il Fiore della Retorica, Venice, $\mathrm{I} 560$, bound in this manner, for presentation to Queen Elizabeth, to whom the work is dedicated [C.20. a. 2I.]. In this example, a pattern is stamped in slight relief upon the sunk and gilt panels at the angles of the boards; the central panel being painted with the arms of England: while the raised ground, surrounding the panels, is covered with red morocco, which is left undecorated except for the name, 'Elisabetta,' and some slight ornament, which are painted upon the leather in gold. In another example, being the cover of a manuscript, written about 1568 , of certain acts of Guidobaldo II., Duke of Urbino, investing Count Pietro Bonarelli of Ancona, and Hippolita, his wife, with the territories of Orciano and Torre, the sunk panels are treated in a similar way, the arms in the central panel being coloured with especial richness : 


\section{Bookbinding}

and the upper ground is painted with arabesques in gold, upon a blue field [Add. Ms. 22,660.]. There is, in the Victoria and Albert Museum, a collection of stamps and tools, used by Persian workmen, in the production of bindings of this nature [Nos. 376$404,1885$.$] ; from which it would appear, that each$ of these sunk panels, was formed by the impression of a single die, or stamp. Bindings of this kind were not adapted to withstand the friction, which must result from their use on a shelf : indeed, they appear to have been used only, by the Italians, as in the foregoing instances, in the adornment of 'principal copies,' to recall a phrase of Lord Herbert's. They are more commonly found with the Lion of St. Mark, painted on the central panel; in which instances, they seem to have been employed as the official bindings of the Statutes and Commissions of the Venetian Senate; an example of which may be seen among the Harleian Manuscripts [No. 3393.]. They are, perhaps, chiefly valuable in showing, how greatly the art of Venice was influenced by that of Persia and the East. The incongruity of the Italian manner, in which the arms on the central panels of these bindings are painted, with that of the rest of the work, which is closely imitated from some Persian original, is not a usual trait of Italian art.

The pattern common to the Aldine bindings, which I have described, and which consists in a panel, ornamented with knots, or letters, within a figured border, although most frequently found upon 


\section{Early Italian Bindings}

the books of that time, is by no means the only one, which was employed by the early Italian binders. Many fine examples are described, or reproduced, in the Catalogue of Bindings exhibited at the Burlington Fine Arts Club, in I89I: and among them, that of a Book of Hours, Paris, I497, which was in the Huth Library, and which bears a design of extraordinary beauty [Case E, No. 28.]. This book is covered with black morocco; and the whole field of the boards is elaborately tooled in blind, over which a border fillet, with the figure of a bird repeated in circles and semi-circles, has been applied in gold, with great art. The boards of a manuscript in the Museum, of Cephalo e l'Aurora, by Niccolò da Correggio, etc., dated 18th August I497 [Add. MS. I6,438.], are decorated with a wreathed niche, or tabernacle, formed by various tools of a Venetian character; and among other examples in the same collection, the following are the more remarkable:-A Book of Hours, bound in black morocco with a folding cover, and tooled in blind with a very beautiful and elaborate design of a Venetian-Arabic character. Late fifteenth century [Royal Ms. 2.A. vii.].-Cicero's Epistles, bound in red morocco; the panels of the boards are decorated with an Oriental pattern, and surrounded by a border worked with solid Venetian tools. Circa I500 [Add. Ms. II,926.].-Three Ducal Commissions in Venetian bindings, ornamented with solid Aldine knots, leaves and borders, and successively dated, 


\section{Bookbinding}

I507, I5I5, I522. The earliest binding bears, also, knots of rope-work and scallop shells, in blind tooling [Add. MS. 20,979, Harleian Ms. 3403, Add. Ms. 20,980.].

About the year 1520 , a more simple pattern was introduced into the decoration of Venetian books, of which the binding on a copy of the Aldine Catullus of 1515 , preserved in the Victoria and Albert Museum [7922-'62.], shows the chief characteristics. This pattern is to be found repeated, with slight variations, upon two other books printed by Aldus, in the same collection: a copy of the Epistolarum Graecarum Collectio, I499, in quarto [30-'65.], and of the Thucydides, 1502, in folio [34-'65.]. In each example, the name of the author, or the title of the book, is stamped within a circle upon the panel of the upper board: an arrangement of simple lines in gold takes the place of the enriched border, which occurs upon the earlier Aldine bindings; and a few leaves, worked by solid tools, chiefly at the angles of the panel, complete the ornament. The fore edge of the boards is furnished with strings, or clasps; and the folio volume has an additional clasp on the head, and tail, edges. In these, as in the earlier bindings, the gilt tooling of the border lines, is invariably accompanied by some lines in blind; an instructive example of that Italian economy, which produces the richest effects in art, by the simplest means. The exuberant sense of decoration, which 


\section{Early Italian Bindings}

is characteristic of early Aldine bindings, no longer distinguishes these later books, decorative as they are. In them, we detect, for the first time, that severe unity, and scholarly precision of design, which afterwards was brought to still finer issues, in the bindings executed for Grolier. This style, which may be termed the second Aldine style, is to be found upon the books of other Venetian printers, than of Aldus; as on a copy of Hesiod, printed by B. Zanetti, in 1537 , and reproduced in the Catalogue of the Burlington Fine Arts Club [Case E, No. 24.].

The history of Venetian binding, from this time, is inseparable from that of the bindings executed for Grolier: and a description of his earlier books is the best account, that can be given of the later bindings, associated with the name of Aldus. The tooling upon a copy of the Institutes of Quintilian, printed at the Aldine press in $\mathrm{I}_{52 \mathrm{I}}$, and reproduced in the Catalogue of the Burlington Club [Case E, No. 32.], presents all the elements from which the early Grolieresque manner was developed. Some of the tools employed in this book are similar to those used upon the earlier Aldine bindings; but, in conjunction with them, is a border formed of an interlaced fillet. The introduction of this fillet is what outwardly distinguishes the Grolieresque, from other Venetian manners: and in such bindings as that of the copy of the De Viris Claris Ordinis Praedicatorum, reproduced in M. Henri 
Bouchot's work, Le Livre, we seem to detect the development of this interlaced fillet, from the earlier knots of Arabic work : but conjectures of this kind might be endlessly hazarded.

Jean Grolier, Vicomte d'Aguisy, the son of Etienne Grolier, and Antoinette Esbarde, his wife, was born at Lyons, in I479. In I510, at the age of thirty-one, he succeeded his father in the office of Treasurer-General of the Duchy of Milan; and on IIth October I516, he married Anne Briçonnet, by whom he had five children. About the year I534, Grolier was sent ambassador by Francis I., to Pope Clement vir.; and, some three years later, he was employed in the Treasury, at Paris. In 1545 , he obtained the reversion of the office of TreasurerGeneral of France; in which he succeeded Charles $\mathrm{du}$ Plessis, some two years later; and continued in the same until his death, which took place at Paris, on the 22nd October 1565 , in his house, the Hôtel de Lyon, near the Porte de Bucy. Grolier was one of those princely scholars, of whom Peiresc afterwards became the type. In Italy, he acquainted himself with the art and erudition of that country: and the encouragement, which he lent to artists and men of letters, was justified by the correctness of his own taste. Franchinus Gaforus, the author of the treatise, De Harmonia Musicorum Instrumentorum, addressed him as 'Musarum Cultor'; and Geoffroy Tory, as 'amateur de bonnes lettres, $\&$ de tous personnages sauans': while Andreas 


\section{Early Italian Bindings}

Assaracus names Musurus, Stephanus Niger, Thylesius, Aldus, Lascaris, and Arpinus, among the number of the poets, historians, and other writers, whom he befriended.

"Vatibus, historicis, addit calcaria ; cunctos Scriptores fovet, his fertque patrocinium. Musurus, Stephanus Niger, atque Thylesius, Aldus, Lascaris, Arpinus, sunt mihi firma fides."

His library, like that of Peiresc, appears to have been in no slight measure intended for the use of the scholars in whose conversation he delighted. The legend, IO. GROLIERII ET AMICORVM, which he stamped upon his bindings, expresses this generous notion of the use of books, at that time not uncommon among the possessors of fine libraries. Brunet mentions a copy of the Quaestiones Naturales, Morales, et de Fato, of Alexander Aphrodisaeus, Venice, I54I, the upper board of which bore the similar legend, 'Io. Chevignardi et Amicorum': and in the British Museum, there is a copy of the Castigationes, by Hermolaus Barbarus, of the Natural Histories of Pliny, Basle, I534, on which is stamped, in a like manner, the words 'RENATI THEVENYN ET AMICORVM' [C. 48. f. 2.]. The books of Maiolus and Marc Lauwrin bore, also, similar inscriptions.

But there is another document, which more clearly illustrates the use, for which Grolier intended his books. M. Le Roux de Lincy, in his Recherches sur 


\section{4 \\ Bookbinding}

Jean Grolier, published at Paris, in I866, has collected with great care and erudition, all that is known of this illustrious person; and has added to his work a catalogue of some 355 volumes, which once formed part of Grolier's library. Among this small number of books, which is not a tenth part of his original collection, there are no fewer than five copies of the Virgil printed at the Aldine press, in 1527 ; and four copies each, of the Hypnerotomachia, and of the Juvenal, the former published in I499, the latter in I50I, by the same printers: while duplicate copies of the same edition of the same work frequently occur in this catalogue. In an age, in which the instincts of the modern collector were happily unknown, Grolier might honestly set forth upon the bindings of such a series of books, that it was intended for the use and enjoyment not only of himself, but, also, of his friends.

The relation of Grolier with Aldus Manutius and his family, and the encouragement, which he gave to their publications, are, also, illustrated in a very significant manner, by this catalogue; in that more than one third of the printed books described in it, are the productions of the Aldine presses. But there are yet more valuable documents extant, which relate to this patronage. In $\mathrm{I}_{5} \mathrm{I} 7$, an edition of Terence was published at Venice, with a letter of dedication to Grolier, signed by Franciscus Asulanus, the father-in-law of Aldus Manutius; but which, 


\section{Early Italian Bindings}

there is reason to suppose, was actually written by Naugerius. The indebtedness of Aldus and his family, to the treasurer, is very graciously acknowledged in this dedication; "Tu Aldum semper singulari quadam benevolentia prosecutus es. Tu eo defuncto omnem in nos amorem illum contulisti ; neque unquam nova in nos quotidie beneficia congerere intermisisti.' In a Latin letter addressed to Franciscus Asulanus, dated 'pridie idus Mart. I519,' Grolier advises that printer, that he may shortly expect the receipt of a corrected copy of the treatise by Budaeus, De Asse, which he wishes to be printed in the form, and with the characters, of the Aldine Politian, published in $\mathrm{r}_{498}$. The expressions, which Grolier uses concerning the type, paper, and margins of the new edition, show with what fastidious taste, he considered the outward appearance of a book. 'Addi volo,' he writes, ' decorem et elegantiam : id praestabit delecta papyrus, litterarum concinnitas, et quae minime sint attritae, spaciosi margines; atque, ut planius dicam, volo eadem forma et notis describi quibus olim Politiani opera impressistis.' This edition of Budaeus's treatise was published, with a dedication to Grolier, in 1522 : and at a later time, in I544, a translation of the Andria and the Eunuchus of Terence into Italian, by Giovanni Giustiniano di Candia, was, also, dedicated to him, by Franciscus Asulanus.

The bindings of the books, which belonged to Grolier, are of two kinds: those, which he caused 


\section{$76 \quad$ Bookbinding}

to be especially bound for himself ; and those, which he purchased already bound, or which were presented to him in fine bindings. Of this latter kind are the Celsus, in the Grenville Library, in which he was content to write his name and legend; and the dedicatory copy of the work by Franchinus Gaforus, De Harmonia Musicorum Instrumentorum, now in the Bibliothèque de l'Arsenal, in which his arms, with those of his wife, are emblazoned. The bindings of these books, for the most part of Italian workmanship, are very variously ornamented.

Among the earlier bindings, which Grolier caused to be especially executed for himself, those of the copies of the Latin and Italian classics printed by Aldus, with italic types, in eights, are not only remarkably similar, one to another; but, also, do not differ, in the essential characteristics of their design and workmanship, from the finer Venetian bindings of that time, in which ordinary copies of the Aldine classics are to be found. From this circumstance, it is commonly concluded, that such bindings, bearing the name and legend of Grolier, of which the British Museum possesses many admirable examples, were executed for him by the successors of Aldus Manutius. They are covered either with brown calf mottled with black; or with morocco, which varies in colour from a reddish brown, to an olive green. The covers are of pasteboard; and the leather is worked to so smooth a surface, that it is sometimes difficult to detect the 


\section{Early Italian Bindings}

nature of the skin. At the beginning and end of each volume is a section, usually formed of a sheet of vellum between two sheets of paper, which are once folded, and sewn with the rest of the book: the outer paper leaf is pasted to the board with the outer vellum leaf, which thus forms a vellum joint; leaving three fly-leaves of paper, and one of vellum. The backs of these books are enriched by five double bands, upon which the sections are sewn, and two kettle-stitch bands, tooled with lines in blind and gold, and the edges are plain gilt. The decoration of the boards consists in an interlaced fillet, formed by two gilt lines, between which blind lines are sometimes run; the angles, and the central space, are relieved by solid figured tools in gold; and the whole is contained by gilt border-lines: on some examples, there is no blind tooling. The name of the author, and sometimes the name of the work, are tooled in the centre of the upper board; and between the border-lines at the tail-edge of the same, the inscription, 'IO. GROLIERII ET AMICORVM.' In the centre of the lower board is the legend;

PORTIO MEA DO
MINE SIT IN
TERRA VI
VENTI
VM

Although the copies bound in this manner, greatly vary in point of date, the same tools continue to 


\section{8 \\ Bookbinding}

be used, as on a Martial printed in I5OI [C. I9. b. 4.] and the third volume of a copy of Pliny's Natural Histories, printed in 1540 [C. 19. b. 23.]. Among other examples of these bindings, which the Museum possesses, are an Ausonius, I5I7 [C. I9. b. 6.], Pomponius Mela, etc., I5I8 [C. I9. b. I8.], and Silius Italicus, I523 [C. I9. b. 28.]. There is, also, among the books of Grolier, a number of volumes in folio, printed at various presses, the bindings of which possess all the characteristics of the smaller Aldine books : of these, an admirable example may be seen on a copy of Wittekindus, De Rebus Gestis Saxonum, Basle, I532 [C. 24. c. I8.]. The smaller Aldine bindings are, certainly, of Italian workmanship; but in some of these larger bindings, there is a certain refinement, which is afterwards found developed in a manner peculiarly French. Something of that delicacy, which became distinctive of the severe art of Florence, after it had been brought by Primaticcio to Fontainebleau, becomes, also, characteristic of Venetian binding when carried into France, a country, at that time, 'more Italian than Italy herself.' This refinement was at first brought about by the use of less heavy tools, and would seem to have been anticipated by the Italian binders ; for certain of the figured tools used in ornamenting a copy of the Aldine Virgil, printed in 1527 [C. I9. b. 29.], for example, are relieved by an engraved line repeating the outline of their forms. The same device may, also, be seen upon another book, bound 


$$
\therefore=
$$




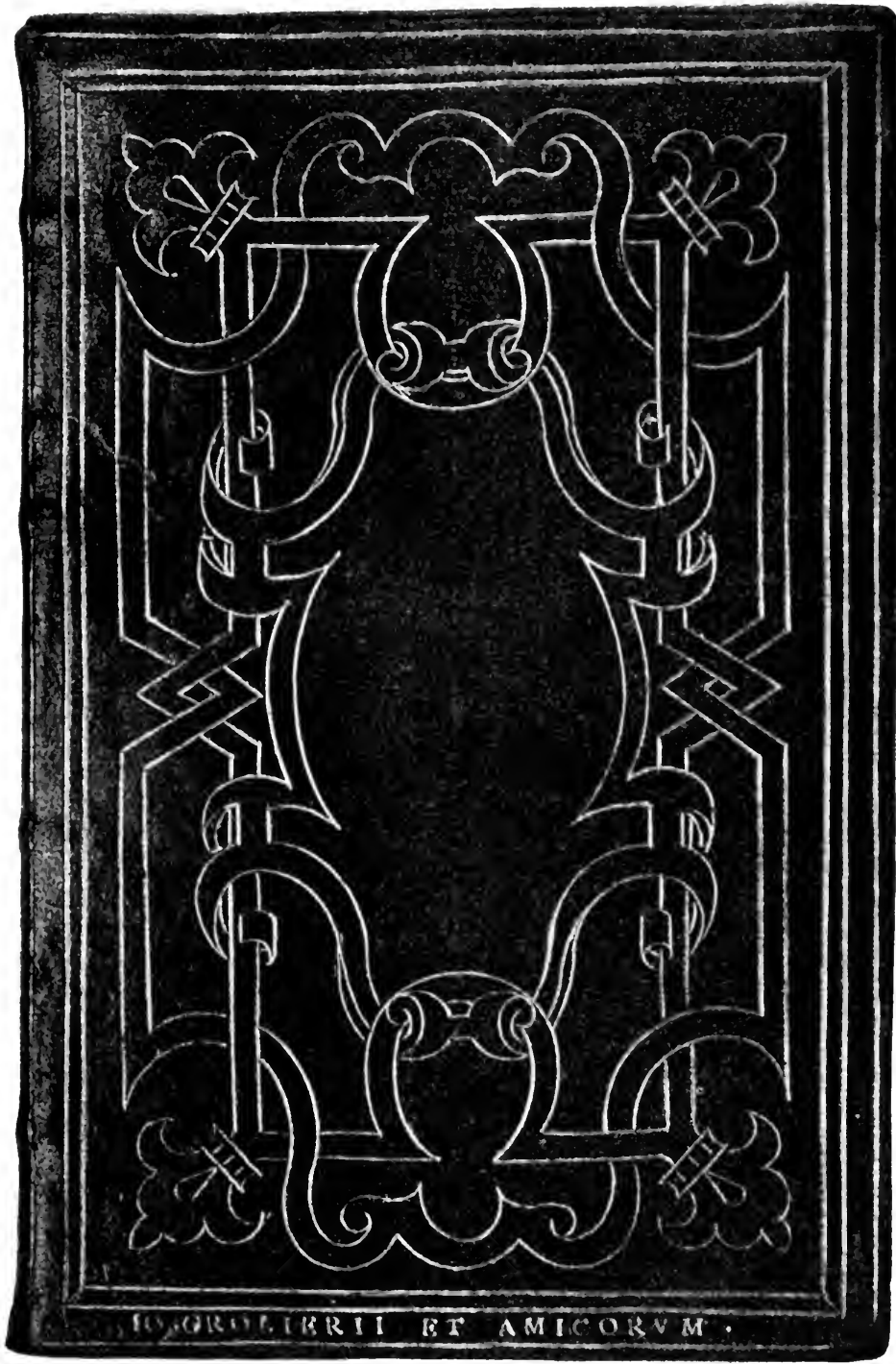

GROLIER BINDING.

BEMBO'S 'GLI ASOLANI,' VENICE, 1530. 


\section{Early Italian Bindings}

for Grolier, in the Museum : the Epitome of Justinus' Histories by Trogus Pompeius, printed at the Aldine press, in 1522 [G. 9056.]. The refinement begun, in this manner, was shortly developed by azuring the tools; that is, by engraving a series of parallel lines upon their face, similar to those by which the colour, azure, is represented in heraldry. The use of azured tools, which afterwards became a characteristic of Lyonese bindings, appears to have been introduced about the year I530: but there is no proof, that such tools were first employed upon the bindings of Grolier. The Museum, however, possesses two admirable examples of his bindings, on which azured tools have been employed: one, a copy of the Commentaries of Theodoret, Bishop of Cyrus, on the Epistles of St. Paul, Florence, I552 [C. 24. f. 15.]; the other, a copy of Il Principe, etc., of Machiavelli, Venice, I540 [C. 27. d. 2.] : both of which are painted bindings. On many of Grolier's books no flowered tools are used; as on a copy of Gli A solani of Bembo, Venice, I530 [C. I9. c. 9.]; the lower board of which is figured in Plate III. The back of this book is without bands, and is tooled with a kind of fish-scale pattern. In some instances, the design, which is worked entirely by fillets and gouges, assumes an architectonic character : of this a copy of the prose works of Pontanus, Venice, I5I2, may be cited as an example [G. Io,046.]. The single-line scroll work, which is ornamented with azured tools, and interwoven with the fillet 
upon some examples, gradually becomes, in the later bindings, as important an element in the design, as the interlacings: while upon one example, Discorso sopra le Medaglie Antiche, Venice, I559, reproduced among M. Henri Bouchot's Facsimiles of Bindings in the Bibliothèque Nationale [Pl. xxIv.], the fillet disappears entirely, and the scroll work forms the entire design. It may be added, that the legend, 'Let my portion, O Lord, be in the land of the living,' is adapted from the verse of Psalm cxlii., which runs in the Vulgate, 'Clamavi ad te, Domine; dixi: Tu es spes mea, portio mea in terra viventium.' A second legend, 'Tanquam ventus est vita mea,' taken from the 7 th Chapter of the Book of Job, verse 7, 'O remember my life is wind,' occurs upon two books described by Le Roux de Lincy; a third out of Virgil, Aen. vi. 743 , 'Quisque suos patimur manes,' upon a copy of the Vulgate, Paris, I558, catalogued by Mr. Quaritch; while a fourth, 'Aeque difficulter,' which might be translated, 'The golden mean is hard,' is sometimes found, as on a copy of the treatise, Divina Proportione, by Luca Paccioli, Venice, I509, exhibited at the Burlington Fine Arts Club [Case F, No. 7.]. Occasionally Grolier's arms, az., three bezants or, in point, with three mullets arg., in chief, occur upon a shield of an Italian character : and other arms and legends are to be found emblazoned, or written, on the pages of other volumes.

Although the bindings of Grolier are solidly for- 


\section{Early Italian Bindings}

warded, they lack that perfection, which the French binders of the seventeenth and eighteenth centuries gave to their work. The tooling, especially, is executed with great freedom, but slight attention being given to any nicety in the joints of the fillets and gouges. A celebrated Parisian binder used to show an original Grolier, beside a copy of its design made by himself, in which he had corrected all the curves of the original with a geometrical accuracy, and executed the joints and mitres with absolute precision. In brief, he had expressed, in his own opinion, the design of Grolier's binder, as that workman would have expressed it, had he been a perfect master of his art. As an example of technical skill, this copy was an extraordinary production; but as a work of art, it wanted that vitality, which is inseparable from the accidents of the hand in spontaneous expression, and in which the charm of the manual arts must largely consist. This freedom of handling in tooling, is like a good manner in painting, or drawing: and takes us far more,

'than when art

Is too precise in every part.'

And not only in art, is this so, but in nature herself ; a trait which Marcus Aurelius has felicitously touched upon, in one of the most charming of his meditations, where he says: "This, also, thou must observe, that whatsoever it is that naturally doth happen to things natural, hath somewhat in itself 


\section{2 \\ Bookbinding}

that is pleasing and attractive; as a loaf when it is baked, some parts of it cleave as it were, and part asunder, and yet those parts of it, though in some sort it be against the art and intention of the baking itself, that they are thus cleft and parted, they become it well nevertheless and have a certain property to stir the appetite.' And so, in a fine binding of Grolier's, the free execution, which is, as it were, against the art and intention of the design itself, is exactly that, which becomes it, and lends charm to it. Express the same design, which is, in idea, one, entire and exact, indeed, almost a geometrical figure; express such a design with an accuracy, equal to the accuracy of its conception, and the whole charm of it is gone. It is dull and lifeless; little better than any other book, tooled in the so-called Grolier style, which is now common to every binder's workshop.

There are two circumstances, which have tended to make the name of Grolier, one of the most remarkable in the history of bookbinding. His are the first gilt bindings, which are known to have been specially executed for an individual collector, in contradistinction to those executed for the stationers. While in no other series of early gilt bindings, is the same fine, scrupulous taste constantly brought to bear upon a distinguished manner of design, which is slowly developed during the course of some thirty years. But the question remains, in what degree is this fine taste to be attributed to 


\section{Early Italian Bindings}

Grolier himself; and in what to the workman, or workmen, whom he employed? Are these bindings to be considered as the productions of French, or Italian, art? To speak absolutely upon this point is impossible ; but the real explanation of the question is, probably, the following one. The bindings of his Aldine volumes are, without doubt, of Italian workmanship; having been executed, in every probability, by Venetian binders : and these appear to have furnished the model, according to which his other bindings were worked. Peiresc, who resembles Grolier in his fine taste, and in his love and munificent patronage of the arts, constantly employed a binder in his own house, as I shall afterwards relate: nor was it inconsistent with Italian tradition, for a great personage, to retain skilful artificers, to work in his palace. John Evelyn, in his Diary, speaks of the artists, who were variously employed in the Uffizi, by the Grand Duke of Florence; and other instances may be found in such books as Cellini's Autobiography. In such sort, did Grolier, for so I am inclined to believe, retain in his house an Italian binder, whose productions were controlled by the same scrupulous taste of the Treasurer, which we find determining the form of the Aldine edition of Budaeus's treatise. When Grolier was called to Paris, about the year I537, it must be concluded, that he carried this workman, thither with him; if we are to account for the continuity of style, in the design of his 


\section{$84 \quad$ Bookbinding}

bindings. Transplanted into France, that refinement upon the Italian manner, which distinguished the productions of this binder, and which is, in the first instance, to be attributed to the personal taste of Grolier, was presently developed in the way in which it appears upon his later bindings. In the essential principles of design, the art of this workman remained wholly Italian; but in this refinement, his productions exhibit a trait, which is peculiarly French. To class them with the bindings of Francis I. or of Henry II., is certainly uncritical; since they invariably possess, what the truly French bindings of this age never possessed, that subtle complexure of qualities, included by Goethe in the term, 'architectonice,' which distinguished the art of Italy, at this time; as it distinguished the art of Greece, in the times of antiquity.

Second only, in repute, to the bindings of Grolier, are those which bear the name of Thomas Maiolus. Of the history of this collector, nothing is known, except that he enjoyed the conversation of Grolier, and that he was still living in I555. There are two books, one a copy of a translation of the Psalms into Italian, Venice, 1534 , described by Brunet ; the other a copy of the Offices, and other works of Cicero, Basle, I528, in the Public Library, at Lyons, on whose bindings are stamped the name and legend of Maiolus, and in which Grolier has written his name, or motto. These are the only extant docu- 


\section{Early Italian Bindings 85}

ments of their friendship. In I497, Aldus Manutius published at Venice, two Latin works, entitled $D e$ Gradibus Medicinarum, and Epiphyllides in Dialecticis, by Laurentius Maiolus, who is thought to have been a blood-relation, perhaps an uncle, of the possessor of the books. In a prefatory letter, Aldus speaks of Laurentius Maiolus, the Genoese, as a man singularly learned, and of an admirable wit: adding that he professed philosophy at Ferrara, where he was especially favoured by Ercole d'Este.

In the Libri sale was a copy of a Ceremoniale, Venice, 1516, the binding of which was stamped with the legend: Michaeli Maio. C. OR., which M. Libri read, in the preface to his catalogue, thus : Michaeli Maioli Caesa. Oratio. Again, M. Aimé Vingtrinier, in a tract entitled, Maioli et sa famille, Paris, I89I, finds in the name Maiolus, a Latinised form of Mayol, the name of the illustrious Provençal house of Saint Mayol, fourth Abbot of Cluny. Much, indeed, has been conjectured, but very little discovered, concerning Maiolus. These are the only notices concerning him, which are worth any serious consideration.

The kind of design, which is most commonly found on his bindings, consists in a richly floriated border, forming a panel, in the centre of which is a cartouche stamped with the title of the book. A copy of the Hypnerotomachia, Venice, I499, in the British Museum, is bound in this manner [C. 24. c. I9.] : the book is covered with black morocco; 
and the panel of the upper board inlaid with citron morocco. Both solid and azured tools are used in the border, the ground of which is studded with gold points : and the back is without bands, and ornamented with a continuous pattern, similar to that of the boards. Within the border, on the tail edge of the upper board, is the legend, 'тно. MAIOLI ET AMICORVM': and on the cartouche of the lower board is a cypher, which, according to M. Guigard in his Nouvel Armorial du Bibliophile, is composed of the letters $\mathrm{A}, \mathrm{E}, \mathrm{H}, \mathrm{I}, \mathrm{L}, \mathrm{M}, \mathrm{O}, \mathrm{P}, \mathrm{S}, \mathrm{T}$; forming the name 'E. P. THOMAS MAIOLI.' But this explanation cannot be accepted, as an $\mathrm{N}$, and an $R$, rather than a $P$, are plainly discernible in this cypher, which, as it takes the place of any legend, probably does not stand for a name always accompanying it at length.

Another binding of this kind covering a copy of the Commentaries of Caesar, Rome, I489 [C. I9. d. 24.], is, also, in the Museum. A third, similar, but more beautiful design, of a very Italianate character, the Histories of Sallust, Venice, I546, was exhibited by Mr. Huth at the Exhibition of the Burlington Fine Arts Club, and is reproduced in their catalogue, [Case F. No. 2I.]. In other examples of a more simple kind, the border entirely consists in gilt and blind lines, the cartouche in the centre of the panel alone being ornamented; as on a copy of the first volume of the collections, Delle Navigationi et Viaggi, by sundry writers, Venice, 


\section{Early Italian Bindings}

I550 [C. 46. i.]. On another binding, that of a copy of the Symbolicae Quaestiones, of Achilles Bocchius, Bologna, I555, the border fillet is itself returned, so as to form the cartouche [C. 27. f. 9.]. On the lower board of this book occurs the enigmatical legend, 'INIMICI MEI MEA MICHI NON ME MICHI'; of which the probable interpretation is, 'Possunt inimici mei mea mihi eripere, non me mihi '; 'My enemies are able to take mine from me, not me from myself' : below, on the border fillet, the name of the possessor is stamped at length, 'Thomae maioli ET AMicorvm.' The leather, in which both of these latter books are covered, is brown morocco, marbled with black, the grain of the skin being curiously filled in with gold; a peculiarity which I have not observed elsewhere.

The design upon certain other books, bearing Maiolus' name, consists in an interlaced fillet, the interstices of which are filled with scroll-work, ornamented with azured tools; as upon some of the later bindings executed for Grolier; but with this difference, that the character of the interlaced fillet is less architectural, while the scroll-work becomes a principal part of the ornament. A copy of the Roman Histories of Florus, Paris, I539, in the Grenville Library, is tooled in this manner [G. 9138.]: the back is richly ornamented, without bands ; and the cypher of Maiolus is stamped on the lower board. This florid kind of design is very characteristic of the binding executed for this collector. 
On the other hand, the copy of the Noctes Atticae of Aulus Gellius, Venice, I5I5, in the Spencer Library, which was exhibited at the Burlington Fine Arts Club, and which is reproduced in their catalogue [Case F, No. I7.], bears a cartouche of a severely architectural character, designed with great simplicity; and in marked contrast to that of the Florus in the Grenville Library.

The bindings executed for Maiolus, considered as a whole, are certainly inferior to those executed for Grolier, in regard to the fineness and beauty of their design. They are, for the most part, more florid in character than the bindings of Grolier : and they generally want that scholarly simplicity, and scrupulous taste, which distinguish the books of the Treasurer. M. Aimé Vingtrinier, in his pamphlet, Maioli et sa famille, is of the opinion, that the bindings of this collector are of Lyonese workmanship : and there are several characteristics of his books, which seem to bear out this opinion. One of these is the frequent use of azured tools: indeed, on every example of a binding executed for Maiolus, which I have yet seen, the flowered tools are invariably, either azured, or executed in outline, and filled in with colour. Another common characteristic of the bindings of this collector, is the absence of raised bands upon the back. This treatment of the back, which afterwards was much affected by the later French binders, particularly by those, who worked in the style associated with the names of 


\section{Early Italian Bindings}

Nicolas and Clovis Ève, must always be considered as a French characteristic; in contradistinction to the tendency of the Italian binders, to increase the size and projection of their bands, for purposes of decoration, beyond what was actually necessary in the mere forwarding of the book. Again, in these bindings of Maiolus, there is a florid vigour of design, peculiarly Italian : and a certain heaviness in the gilding unlike that refinement, which distinguishes the work of the Parisian binders. These mingled French and Italian characteristics, coupled with the frequent use of azured tools, tend, I think, to support M. Vingtrinier's opinion that these bindings are of Lyonese workmanship.

There is yet another collector, who enjoyed the acquaintance of Grolier, and whose books, if less elaborately bound, are yet more rare, than those of Maiolus. This is Marc Lauwrin, or Laurin, as his name is variously spelt in French, Seigneur de Watervliet. Born at Bruges of an illustrious family, a scholar and an accomplished antiquary, he is still remembered for the assistance, which he rendered to Hubert Goltzius, in his famous work upon the illustrations of Greek and Roman history, afforded by the medals of Antiquity; four volumes of which were published at Bruges, in $1563-76$. The second volume of a Cicero, bearing Lauwrin's name and legend, was exhibited at the Burlington Fine Arts Club, and is figured in their catalogue [Case F, No. I5. b.]. On the upper lid of this book, which 


\section{Bookbinding}

is bound in black morocco, the name of the author is lettered on a simple floriated label ; while below, on a second label of an oblong shape, formed by a single gold, is the name: M. LAVRINI ET AMICORVM ; the whole being surrounded by a border-line of gold, between two lines in 'blind. The taste shown in the choice and disposition of these simple elements, and the effect obtained by them, are exceedingly felicitous and distinguished. On the lower board was the legend: VIRTVS IN ARDVO. Another example of a binding executed for Lauwrin of a similar character, and bearing the same legend, is figured in the Nouvel Armorial du Bibliophile, by Joannes Guigard, Paris, I89o ; and a third, in the British Museum [G. 8320.], encloses the Aldine Xenophon of 1525 . In the Libri sale, was a book in which Lauwrin had written the sentence, "Vita est aqua fluens humana,' in allusion to his title of Watervliet: and on some of the books bound for him, his name and legend are surrounded, also by way of allusion, with branches of laurel. A binding in the Louvre bears the inscription, 'Io. Grolierus M. Laurino D.D.' ; it is described in the catalogue of Le Roux de Lincy, No. IOo ; in whose work, other notices of the scholars and collectors, who enjoyed the conversation of Grolier, may, also, be found.

Some of the finer bindings, executed in Italy about the middle of the sixteenth century, are certainly equal, in point of design, to the most beautiful 


\section{Early Italian Bindings $9 \mathbf{I}$}

bindings of Grolier. A copy of the Hypnerotomachia, Venice, I545, figured in Burlington Fine Arts Catalogue [Case F, No. 24.], is finished with a sense of largeness and virility, only possible to an Italian. But these instances are rare; and the bindings, chiefly in vogue about this time, were the painted bindings, which have more in common with the florid designs executed for Maiolus. These bindings include a great number of examples, done for ecclesiastical and noble personages; and they differ greatly from one another, in regard to the quality of their design and workmanship. For the most part, they incline to a coarseness in the forms, and a crudeness in the colour: but bindings of great beauty are found treated in this manner. What was merely an interlaced fillet, on the bindings of Grolier and Maiolus, is here often elaborated into a kind of cartouche, which fills the whole field of the boards; and is sometimes accompanied by arabesques, worked by a single line, with flowered tools. A fine specimen of a painted binding covers a Book of Hours, Paris, I549, in the collection of the British Museum [C. 27. e. I4.]. The design and colour of this example are admirable: and other instances may be seen on a copy of Antonio Zantani's Medals, Venice, I548 [C. 20. b. 6.], and on a translation into Italian of the Politics of Aristotle, Venice, I55I [C. 20. a. 20.]; both of these bindings are tooled upon calf. But no example in the British Museum is equal to the Missal, bearing the arms 
of Cardinal Gonzaga, which is figured in the Catalogue of the Burlington Fine Arts Club [Case D, No. 5.]; and which is an early specimen of this kind of decoration.

Towards the latter part of the century, these tooled and painted bindings were imitated, and produced, in great numbers by the stationers, with the aid of stamps, or blocks. Having been principally produced by the stationers of Lyons, they are known as Lyonese stamped bindings: but they issued, also, from Italy and from other parts of France. In point of design, both these, and the tooled, painted bindings, are often very Italian in character : although a great number of them must have undoubtedly been produced in France. The stamped bindings were not invariably coloured, but sometimes only gilt : and they show a great variety in their treatment. In some instances, the binding was first stamped in blind, and the colour and gilding afterwards applied by hand; on others, the stamped work was supplemented with tooled borders, to adapt it to the size of the book; on others, the whole field of the stamp is azured, in which case it is generally worked in gold, without colour. MM. Marius-Michel, who discuss, and illustrate, the matter of stamped bindings at length, in their book, La Reliure Française Commerciale, are of opinion, that eighty out of every hundred of the smaller and elaborately-bound books, of the second half of the sixteenth century, have stamped bind- 


\section{Early Italian Bindings}

ings. The Victoria and Albert Museum possesses an interesting series of these small octavo books, bound in this manner, among which are a Cicero in three volumes, Lyons, I555 [229, 229a, 229b-'66.], a Florus, Lyons, I548 [5770-'59.], and a Psalter, Lyons, I542 [33-'65.]. Although not always of considerable artistic value, these books are worth a careful study, showing, as they do, what may be done by legitimate means, with good materials, in producing rich and effective bindings at a low rate of expense. Historically, they carry on the traditions of the Venetian workmen, and the binders of Grolier's books; and form a link, in this regard, between the art of Italy, and the art of France.

There is yet another method of decoration, frequently employed by Italian binders during the first half of the sixteenth century, in the adornment of their books, which I have not alluded to, and which consisted in stamping the leather with dies, cut in intaglio, whereby impressions in relief, imitative in some sort of antique cameos, were produced. Bindings treated in this manner are known as cameo-bindings : and an early and exceedingly fine example may be seen in the Grenville Library, on a copy of Celsus, De Medicina, Venice, I497 [G. 9026.], in which Grolier has written his name : 'Est mei Jo. Grolier Lugd. \& amicorum.' In this instance a cameo is stamped on either cover, as if suspended by a ribband, within a pane formed by a double border, executed in blind tooling. These 


\section{4 \\ Bookbinding}

cameos are exquisitely modelled, and are painted in gold and colours: that on the upper cover, represents Curtius leaping into the gulf : while that on the lower board, the fight of Horatius Cocles on the Sublician bridge. The latter, which contains a great number of minute figures, is finished with extraordinary art and elaboration. The ribbands suspending the cameos, are designed in a very decorative manner, being interspersed with minute roundels in red and gold, and painted in a blue colour. The stamps used in working these cameos were commonly cast in bronze, from known medals and plaquettes. There is scarcely a collection of such things of any note, which does not contain one or more examples of these stamps, or incuse plaquettes, as they are generally called. In the collection of the writer, is a circular stamp of this kind, representing a woman's head, which, unlike the majority of these cast plaquettes, has been boldly cut and chased, apparently from an original design. The late Mr. W. Y. Fletcher pointed out, in the first article of Bibliographica, vol. i., that the two cameos on the Grolier copy of the Celsus, were taken from two well-known plaquettes ascribed to Giovanni delle Corniole. An example of the plaquette representing Curtius leaping into the gulf, is exhibited in the Department of British and Medieval Antiquities, in the British Museum. Another example of great beauty, but of rougher workmanship, is figured in Mr. Quaritch's illustra- 


\section{Early Italian Bindings}

tions [Nos. 8 and 9.]. This book, which is a copy of Joannes Grammaticus In Aristotelem, Venice, I504, is bound in citron morocco, and bears a painted cameo on the centre of either board, which is also tooled with figured borders in gold. Both the cameos, and the borders, differ from one another in design : on the lower lid, Orpheus is represented with his lute. The edges of this book are painted with a Greek fret, in red and blue.

The name, which is chiefly associated with this kind of decoration, is that of Demetrio Canevari, physician to Pope Urban viII., who appears to have inherited a library of books bound in this manner, which remained intact in the Vico Lucoli, at Genoa, until the year I823. The bindings of these books were probably executed by Venetian workmen, between the years I535 and I560; and they could not, therefore, have been made for Demetrio Canevari himself, who was not born until I559. They bear, stamped in the centre of both the upper and lower boards, a cameo of Apollo driving a chariot with two horses, over the sea, towards a rock, on which is Pegasus. The cameo is of an oval form, and is surrounded by the legend: OP $\Theta \Omega \Sigma \mathrm{KAI}$ MH $\Lambda O \Xi I \Omega \Sigma$. The dies, with which this cameo are stamped, varied according to the size of the book: on the larger volumes, the greater diameter of the oval is set upright; on the smaller, lengthways. A fine example of the larger volumes bound in this manner, a copy of the Historia Anglica of 


\section{$96 \quad$ Bookbinding}

Polydore Vergil, Basle, I534, is preserved in the Grenville Library [G. 4762.]. This volume is covered in brown morocco; and the cameos are painted in green, silver and gold. An interlaced and flowered border is worked with solid tools, similar in character to those of the Aldine bindings, about the panels of the boards: and the title is lettered, not only upon the upper lid, but, also, upon the back of the book [Plate II., fig. I.]. This is one of the earliest instances of a back bearing the title of a work, although Le Roux de Lincy notices that some of Grolier's books are thus stamped with his name. An example of one of the smaller volumes of Canevari, may be seen in the Victoria and Albert Museum, Il Petrarcha Spirituale [93'66.]: and some unusually elaborate examples are figured among Mr. Quaritch's illustrations. The solid Venetian tools are an invariable characteristic of these bindings.

The Italian bindings, the chief characteristics of which I have hitherto described, are, for the most part, either of Venetian, or of Lyonese, workmanship. The binding of the Cracherode copy of the Greek Anthology, printed at Florence, in 1494, which is now in the British Museum [C. I9, d. I2.], bears the heads of Philip and Alexander in cameo, and is tooled in gold, with borders of interlaced work, which, though obviously derived from some Venetian original, are designed in a manner peculiar to the Florentine binders. Another example, in which 


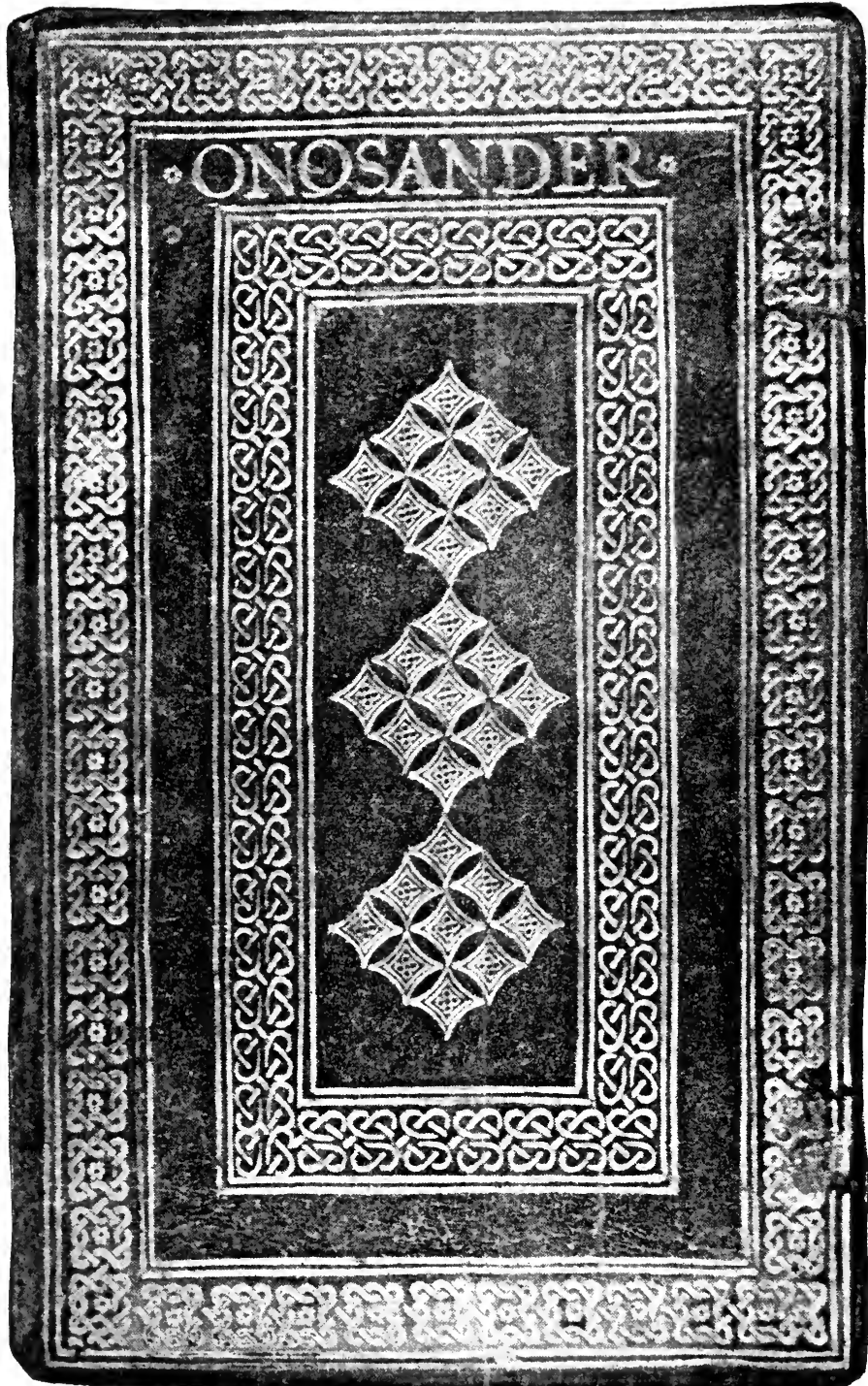





\section{Early Italian Bindings}

this manner becomes still more emphasised, is the binding of a manuscript of Onosander, formerly in the possession of Mr. William Morris, which is figured in Plate IV. Like the copy of the Anthology, this book is bound in red morocco, and the borders are tooled in gold. It is said to have come from the library of Lorenzo de' Medici ; but its binding was apparently executed at the beginning of the sixteenth century. The characteristics of this Florentine manner would be difficult to describe, as the elements of design and the methods of workmanship, which accompany it, differ but slightly, from those used by the Venetian binders: but upon a comparison, the difference between the two manners is sufficiently obvious. The binding of a copy of the Enchiridium Grammatices, of Eufrosino Bonini, Florence, I5I4, also in the British Museum [C. 66. d. 9.], affords another instance of Florentine workmanship, unlike either of the foregoing examples. This book, which is exhibited in the King's Library, is covered in brown morocco; and bears a cameo in high relief of Julius Caesar, repeated on either cover, and sunk into the boards, which are of wood, and of an unusual thickness. A stamp, cast from a well-known plaquette, and corresponding to the head on this binding, is preserved in the Department of Coins and Medals, in the British Museum. By the device, of sinking the cameo into the boards, its projecting surfaces are guarded from friction, which is the chief prac- 


\section{$98 \quad$ Bookbinding}

tical objection to the use of such ornaments upon a binding. The groove, which occurs on the edges of the boards of the binding in question, is thought to have been copied from Greek manuscripts; and is not uncommon in early Italian bindings.

Towards the end of the sixteenth century, Italian bookbinding, in common with the other decorative arts, deteriorated in a very extraordinary degree; but while it lost its beauty, invention and charm, it always retained a certain unity of effect, together with a virile sense of decoration, which gave it an artistic value. 


\section{CHAPTER III}

\section{FRENCH BINDINGS}

That unique tradition of fine binding, which has continued in France, from medieval times to the present day, owes its origin and growth, in no slight measure, to the Guild of St. Jean Latran, which was early established in the city of Paris. An elaborate account of this community was published in I893, by M. Ernest Thoinan, in Les Relieurs Français; and the records and other documents, which that writer has collected in illustration of his subject, contain a mass of information relative to the early history of bookbinding in France, to which nothing comparable is to be found in Italy, or in this country. Unlike the other city guilds of Paris, which arose under the control of the 'prévôt,' or mayor of Paris ; this of St. Jean Latran had its origin in the protection, which the University extended, at a very early time, to all those, who were engaged in the production and sale of books ; the scribes, the illuminators, the binders and the booksellers. It was from this circumstance, that the Parisian stationers became associated with, and settled in, the Quartier de l'Université. A definite guild, or confraternity, seems first to have been founded by them, in I4OI, when 


\section{00 \\ Bookbinding}

Charles vi., by a charter dated Ist June, authorised 'Nicolas de Bosc, J. Postié, H. Marescot, escrivains, Jacques Richier, enlumineur, J. Chapon, libraire, Guillaume Deschamps et Simonet Milon, relieurs, à fonder une confrérie en l'église Saint André des Arcs, sous l'invocation de saint Jean, l'Evangéliste.' This charter was confirmed by Louis xI., at Chartres, in the month of June, 1467 ; and from this act of confirmation, it appears, that the Guild, in common with other medieval guilds, was largely of a religious nature: one of its chief obligations, being the celebration of three masses ; the first for the king, his predecessors, and the University, the second for the living, and the third for the deceased, members of the confraternity. When the Guild was originally founded, its members were 'en grant nombre, riches et oppulenz'; but the times had changed: Paris had become impoverished 'by great wars, famines, mortalities and other pestilences'; and the numbers of the Guild were so diminished, that Louis XI., by this new edict, authorises the annual payment, hitherto made by each member of the confraternity, to be increased, in order that the expenses of the three masses, and the other obligations of the confraternity, might be duly defrayed. This edict, at the same time, requires, that the election of the officers of the Guild should henceforth be made subject to the confirmation of the mayor of Paris ' qui sera leur conservateur et gardien.'

In the year 1582 , the members of the Guild con- 


\section{French Bindings}

cluded an agreement with the General and Chapter of the Mathurin Fathers, by which the religious ceremonies of the confraternity, hitherto celebrated in the Church of St. André des Arcs, should in future be held in their church in the Quartier de l'Université. The articles of this agreement are to be found printed in a rare little book, published by Lottin, and entitled, La Messe du Martyre de S. Jean, Apótre et Évangeliste, devant la Porte Latine à Rome, patron de la communauté des Libraires, etc., Paris, I779: which contains many things of value upon this subject.

The statutes of the Guild were not formally authorised until $\mathrm{I} 6 \mathrm{I} 8$, when, by letters patent of the king, they were drawn up in thirty-eight articles, approved by the Mayor of Paris, and enrolled by the Parliament. By these statutes, the affairs of the Guild were to be administered by a master and four wardens : and the exercise, within the city of Paris, of all trades involved in the production of books, such as printing, binding and publishing, came under its control. In order to attain to the freedom of the Guild, without which no one could follow any of these callings in the quality of a master, it was necessary, that its members should have been bound apprentice, for a term of five years, to a masterbinder in Paris; that they should have served as journeymen, for a further term of not less than three years ; and that, lastly, before their admission, two freemen should bear witness to their ability, in the 


\section{ro2 Bookbinding}

presence of the master and his colleagues. Amongst other regulations, such as the grant of certain privileges to the sons and widows of freemen, was one forbidding any master-binder to pursue his calling without the precinct of the Quartier de l'Université. In this way the history of the French binders came to be invariably associated with that quarter of Paris, which still remains one of the most interesting parts of the city.

From this time, the history of the Guild becomes chiefly a history of the disputes, which exercised its members. During the sixteenth century, its privileges had been freely extended to the gilders of books; but as their trade increased in importance, so great a number of gilders applied for admission, that their claims were stoutly resisted by the stationers, with whom they came into competition. In one of the law-suits, which arose out of these disputes, an attorney, speaking for the master and wardens of the Guild, taunted two gilders, Pigoreau and Ballagny, with having exchanged the gilding of boots, for the gilding of books, as a more lucrative and honourable employment. This allusion has frequently been held to prove, that during the sixteenth century, the gilders who worked for the bookbinders, worked also, upon other leather-work, such as belts or caskets. M. Thoinan, however, points out, that both Pigoreau and Ballagny had received their freedom as gilders, in strict conformity to the statutes of the Guild, in regard both to their apprenticeship, and to their 


\section{French Bindings}

other obligations. Any serious meaning cannot, therefore, in his opinion, be attached to this remark of the attorney, which amounts to nothing more than the sarcasm of a special pleader.

Of the subsequent disputes, which disturbed the Guild, it will not be possible here to speak at length. The chief of these led to the separation of the printers and stationers, from the binders and gilders; who had hitherto been associated together under the style of 'Le Communauté des Libraires Imprimeurs et Relieurs.' The edict, constituting the binders and gilders a distinct community, is dated 7 th September I686; and the statutes, which are contained in its articles, agree, for the most part, with those authorised in the year I6I8: the privileges, granted to the sons and widows of freemen, are extended; and the precinct of the Quartier de l'Université in which its members were alone permitted to follow their professions, is strictly defined. One article, which afterwards led to some difficulties, called upon all freemen, who enjoyed the double qualities of stationer and bookbinder, to declare, which of these two they would in future elect to follow. Not only was this article ignored by several ' libraires-relieurs'; but the wardens, who had been nominated by the king to administer the affairs of the Guild for a term of three years, continued in office, and otherwise acted, in contravention of the statutes. On the 24th March I698, forty-seven of the elder freemen represented to the civil authorities, that more 


\section{04 Bookbinding}

than thirty persons had been admitted by the wardens, to the freedom of the Guild, of which the greater number had not satisfied the provisions of the statutes, with regard to their apprenticeship. These irregularities were at length corrected: and the members of the community proceeded to the election of wardens, on the 3Ist May I698, in accordance with the statutes. By its provisions, two wardens were to be annually elected for the term of two years; there being always four wardens in office, at any one time. Of these officers, we possess a complete list from the year I698, to the year I775; among whom were many binders of celebrity.

The entire and final separation of the booksellers and printers, from the binders and gilders, did not take place until I730; the two Guilds having continued to celebrate their religious ceremonies together, notwithstanding their severance in secular matters. In that year they came to an agreement, which was designed to terminate all future difficulties: and the binders and gilders retired to the Church of St. Hilaire, where they re-established their confraternity.

In 1776 , an attempt was carried out by Turgot to suppress the whole of the city Guilds of Paris : but upon the dismissal of that minister by Louis XIV., they were reconstituted by an Edict, promulgated in the same year ; and the act of their final suppression was reserved for the Revolution. By a decree of the Assembly, I7th March I79I, the Guild of Binders 


\section{French Bindings}

and Gilders, in common with the other city guilds, ceased to exist.

Such, briefly, is the history of the Guild of St. Jean Latran : let us now turn to discuss the notices which have come down to us, of the principal binders, and their work. The earliest gold-tooled bindings of France recall those stamped bindings of the fifteenth century, the boards of which are ornamented by parallel rolls of ornament, running from the head to the tail of the volume The copy on vellum, presented to Henry virr. by Thomas Linacre, of his translation into Latin of Galen's Methodus Medendi, Paris, I5I9, which is still preserved among the books of the Old Royal Collection [C. I9, e. I7.], is bound in this manner; and the exceedingly rare bindings of Louis xII., examples of which are figured in M. Guigard's Nouvel Armorial, show the same characteristics. It is not, however, until the reign of François I., that the influence of Italian art plainly asserts itself, in the work of the French gilders; and of this influence, the bindings executed for that monarch, 'non minus litteris, quam armis clarus,' says Angelo Boccha of him in the notice of his library, remain the principal examples. In the Grenville Library is a Suetonius, Venice, I52I, which retains its original boards, stamped with the arms, crowned initial and device of François I. [G. 9052.]. But this simple binding, even in its unmutilated state, was scarcely characteristic of the fine gilding of this period. On the richer bindings 


\section{06 Bookbinding}

executed for this king, the ornament usually consists of a floriated and interlaced fillet, surrounded by a border : while the field of the panel is studded with the crowned $\mathrm{F}$ and the fleur-de-lys. His arms are stamped in the centre of the boards; and his device, a salamander in flames, is sometimes accompanied by the legend, 'Nutrio et extinguo' : a binding of this kind, with others of a simple character, is figured by M. Henri Bouchot, in Les Reliures d'Art a la Bibliothèque Nationale [PI. XxvII. to XxxI.]. A far more remarkable piece of gilding executed for this king, occurs on a copy of the Vulgate, Paris, I538-40, in the Bibliothèque Nationale; of which MM. Marius-Michel publish a reproduction in La Reliure Frangaise [Pl. I.]. The principal decoration of this volume consists in the repetition of a large tool, of the solid Venetian character, which is associated with the name of Aldus. It is of the figure, which commonly occurs as a centre-piece, on Venetian books; and it may well have been designed and cut by an Italian workman. But the manner in which this tool is repeated over the field of the boards, so as to form a kind of diaper, and the interspaces studded by the crowned $\mathrm{F}$, is wholly and peculiarly French.

The name of one bookseller, who bound for François I., has come down to us in Etienne, the son of Pierre Roffet, called, le Faucheur. The imprint of a book published by him in I534, Premier livre de la Métamorphose d'Ovide translaté du latin en françois, 


\section{French Bindings}

by Clément Marot, runs thus : ' On les vend à Paris, sur le pont Sainct Michel, chez Etienne Roffet, dict le Faulcheur.' Between the date of the publication of this book, and that of the 'privilège,' 23rd February, I539, of another work, Euvres de Hugues Salel, Roffet was appointed Binder to the King; perhaps on the death of Guillaume Eustace, whose name occurs in the catalogue of Lottin, under the year I493, and who styles himself, on a book printed for him in I5I4, ' libraire du Roy et relieur iuré de l'Université de Paris.' A third book published by Roffet, in I540, Brièfve et fructueuse exposition sur les Epistres Sainct Paul aux Romains et Hébreux, par Primasius, translaté de latin en langue vulgaire françoise par Jehan de Gaigny, has the imprint, 'a Paris pour Estienne Roffet dict le Faulcheur, libraire, \& relieur du Roy, demourant sus le pont Sainct Michel a Lenseigne de la Rose ' : while on the imprint of a translation from Lactantius, published by him in 1546, his sign is described as 'la Rose blanche.' Of the work done by this binder for the king, we have some evidence in the following entry, which occurs in the accounts of the Master of the Chamber, and which is printed by the Marquis Léon de Laborde in the second volume of his Comptes des Bâtiments du Roi, Paris, 1877-80, vol. ii. p. 233 :-

'A maistre Claude Chappuys, libraire du dit seigneur la somme de $\mathrm{VI}^{\mathrm{xx}} \mathrm{Xl}$. $\mathrm{X}$ solz tournois pour son remboursement de semblable somme qu'il a desboursée de ses deniers à ung libraire de Paris nommê le 


\section{08 Bookbinding}

Faucheux, pour avoir de l'ordonnance et commandement du dit Seigneur, rabillé, relié et doré plusieurs livres de sa librairie en la forme et manière d'ung evangelier jà relié et doré par icelluy le Faucheux, escript de lettres d'or et d'autres.'

Contemporaneous with these bindings of François I. and those of Grolier, are the stamped bindings of Geofroy Tory, the most remarkable stamped work in gold, which has been produced by any stationer. This extraordinary artist was born about the year I 485 , and having completed his education in Italy, returned to France, and settled at Paris, in the quality of a printer, bookseller and binder. He did not, in all probability, do more than to direct the execution of these bindings, and give the designs for their stamps; in the same way as he gave the designs for the celebrated cuts, which adorn the books of his impression. These stamps, for the most part, form panels of arabesque work, which are used as the principal decoration of the boards ; although borders and other ornaments are sometimes added. The forms of these elegant arabesques are imitated from those of contemporary Italian work; but the manner in which they are designed, is wholly peculiar to this designer, like that which marks the ornaments of his Hours, and other cuts. For the first time in the history of bookbinding, we are able to recognise, in a piece of gilding, the unmistakable personality of an original artist ; a trait, which we are apt entirely to associate with 


$$
\therefore=
$$




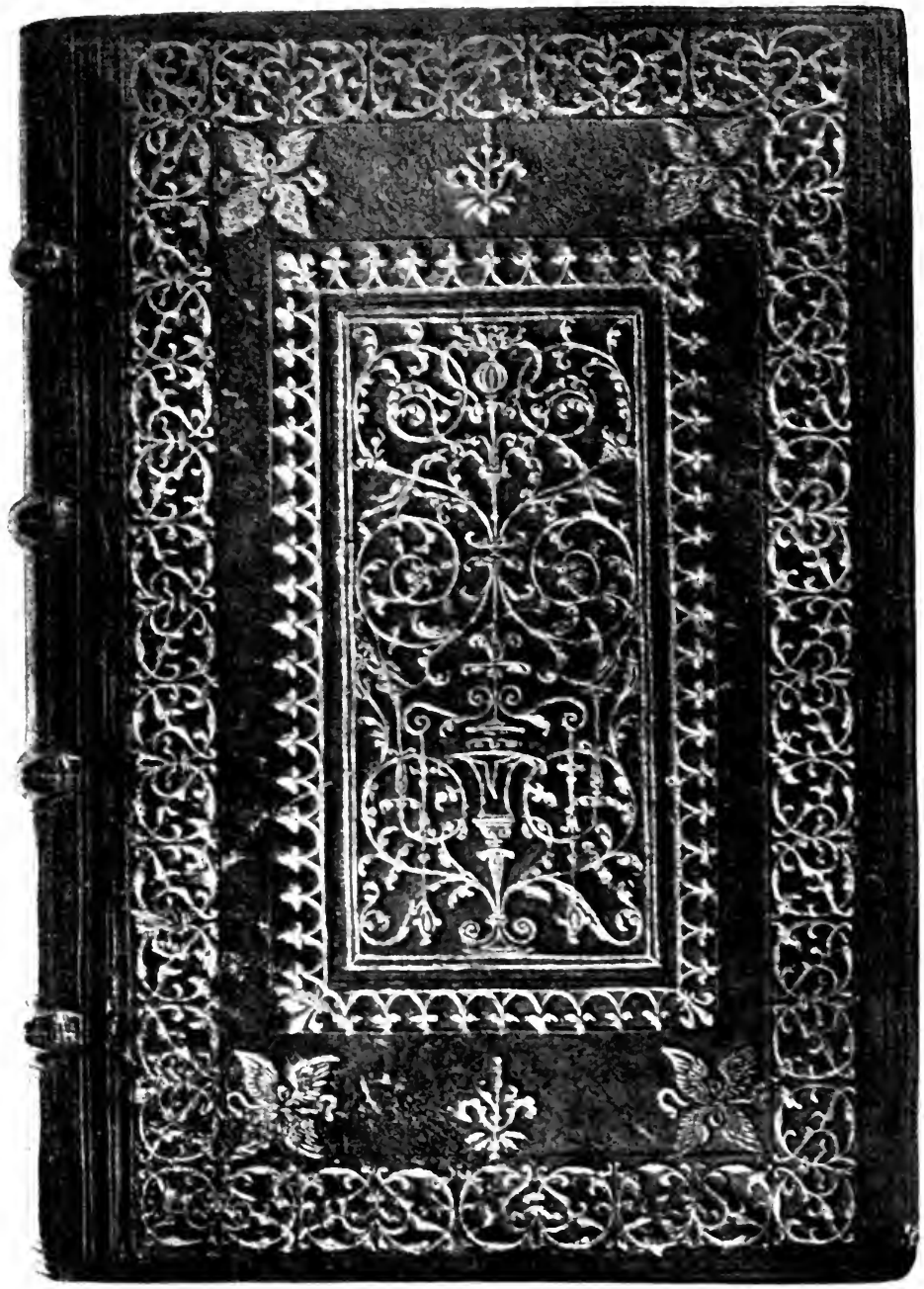

GEOFFROY TORY.

(PETRARCH, 1525. ) 


\section{French Bindings}

the work of modern binders. In the British Museum, is a volume of Petrarch, Venice, I525, bound by Geofroy Tory [C. 47. g.]. Books were, at this time, still issued by the printer in sheets, and copies were bound by the bookseller, according to the demand for them : it was in this way, that a book printed at Venice came to be bound by Tory; while a copy of his own book of Hours, in the Museum, has a contemporary painted binding, which appears to be of English workmanship. In the lower part of the panel of the Petrarch, which is figured in Plate v., Tory's sign of the 'pot cassé' forms a part of the arabesques. On other examples, one of which is reproduced by M. Henri Bouchot in Les Reliures d'Art à la Bibliotheque Nationale [Pl. XxxirI.], the broken vase is pierced by a 'toret,' or wimble. This sign of the 'pot cassé' first occurs in a cut, at the foot of a Latin poem, written by Tory on the death of his little daughter Agnes, and published on the I5th February, I523. Here the vase, pierced by the wimble, stands chained upon a closed book. This device, designed in obvious allusion to the death of his daughter, was afterwards somewhat modified; some flowers being placed in the vase, and a little winged figure omitted : in this form it was afterwards used by him, as the mark of his press. In his Champfleury, he gives the following explanation of this mark, expressed with all the imagery characteristic of that phase of the Renaissance, which produced the Christiad of Vida, 


\section{IO \\ Bookbinding}

and in which Tory moved and had his being. 'Premierement en icelle $\mathrm{y}$ a ung vase antique qui est casse, par lequel passe ung toret. Ce dict vase et pot casse signifie nostre corps, qui est ung pot de terre. Le toret signifie Fatum, qui perce et passe foible et fort. Soubz icelluy pot casse y a ung livre clos a trois chaines et cathenats, qui signifie que apres que nostre corps est casse par mort, sa vie est close des trois deesses fatales. Cestuy livre est si bien clos, quil ny a celluy qui y sceust rien veoir, sil ne scaict les segrets des cathenats, et principallement du cathenat rond, qui est clos et signe a lettres. Aussi apres que le livre de nostre vie est clos, il ny a plus homme qui y puisse rien ouvrir, si non celluy qui scaict les segrets, et celluy est Dieu, qui seul scaict et cognoist avant et apres nostre mort, quil a este, quil est et quil sera de nous. Le feuillage et les fleurs qui sont au dict pot signifient les vertus que nostre corps pouvoit avoir en soy durant sa vie. Les rayons de soleil qui sont au dessus et au pres du toret et du pot signifient linspiration que Dieu nous donne en nous exerceant a vertus et bonnes operations. Aupres dudict pot casse y a en escript : NON PLvs, qui sont deux dictions monosyllabes, tant en francois quen latin, qui signifient ce que Pittacus disoit iadis en son grec: $M \eta \delta \epsilon \nu$ a $\alpha \alpha$, nihil nimis. Ne disons, ne ne faisons chose sans mesure ne sans raison, si non en extreme necessite: adversus quam nec Dii quidem pugnant. Mais disons et faisons SIC. vT. VEL. vT. Cest a dire ainsi comme nous 


\section{French Bindings}

debvons, ou au moings mal que pouvons. Si nous voulons bien faire, Dieu nous aidera, et pour ce ay ie escript tout au dessus: MENTI BONAE DEvS occVRRIT, cest a dire Dieu vient au devant de la bonne volunte et luy aide.' Geofroy Tory died in I533, and his business was carried on by his widow, until it was transferred by her to Olivier Mallard in I535. In this way, bindings bearing the stamps of Tory occasionally occur, which are of a date subsequent to that of his death. [Auguste Bernard's Geofroy Tory, Peintre et Graveur, Paris, I865.].

The characteristics, which distinguish these bindings of François I. from contemporary Italian work, become yet more defined in the bindings, executed for Henri II. and Diane de Poitiers. I have already remarked a certain delicacy and refinement, which distinguish the work of the French gilders : but other traits of French Art remain to be noticed, which relate rather to matters of taste and composition. Diane de Poitiers, the daughter of Jean de Poitiers, Seigneur de Saint Vallier, was born 3rd September, I499, and was married at an early age to Louis de Brezé, Comte de Maulevrier. Having become a widow in I53I, she took for her device an arrow, surrounded by branches of laurel, and rising from a tomb, with this inscription, 'Sola vivit in illo.' At a later time, when the Duc d'Orleans, afterwards Henri II., fell in love with her, the allegory became embarrassing ; but Diane was possessed of spirit, and found the means to improve her royal amour, 


\section{I 2}

\section{Bookbinding}

without appearing to abandon the regard, which she had vowed for the memory of her husband. She withdrew the tomb, and merely changed the gender of the pronoun: the legend, 'Sola vivit in illa,' retaining nothing of a compromising nature, became with the arrow and laurels the device, which is commonly found upon her books. Such is theaccount, which M. Bauchart gives of Diane and her scruples, and which he illustrates in his book, Les Femmes Bibliophiles de France, by a reproduction of one of her bindings, tooled with this device on the lower board : on the upper board are the arms of Brezé, impaling those of Poitiers. The original, a copy of the Orationes Basilii, archiepiscopi Caesareae Cappadociae, Paris, 1556 , is in the Town Library at Rheims.

On another binding executed for her, and reproduced among Mr. Quaritch's illustrations [Nos. I9 and 20], two legends take the place of the arms and device. Of these, the significant sentiment, stamped on the upper lid, 'Consequitur quodcunque petit,' is but an excuse for the elaborate compliment to the king, which follows on the lower board, 'Nihil amplius optat.' This volume, which is a copy of the dialogues of Bartholomaeus Camerarius, $D e$ Praedestinatione, Paris, I556, is covered with white morocco, on which the design is tooled in black. Bows, arrows, quivers, crescent moons, the crowned $\mathrm{H}$ and the cypher composed of two D's reversed and interlaced with an $\mathrm{H}$, compose the chief part of the other decorations of these books. 


\section{French Bindings}

Henri succeeded his father in 1547 , and Diane de Poitiers was created Duchess of Valentinois. After the death of her lover, she retired to the Chatteau d'Anet, still adding to her library until the time of her death in 1566 . There her books remained until I723, when they were sold, consequent upon the death of the Princesse de Condé, to whom the castle then belonged. A list is given by M. Bauchart of those volumes of her library, which he has been able to trace: but they only number some thirtyfive. The library of Henri II., however, remains for the most part intact ; and is now preserved in the Bibliothèque Nationale at Paris. Examples of his bindings are, however, to be found occasionally in other libraries : the British Museum possessing, at least, three of his books. The style of these bindings is generally more simple, than that of the books bound for Diane de Poitiers: a figured or interlaced border, forming a panel, on which the arms of the king are stamped, composes the entire decoration of one of the books in the Museum, Le Livre des Statuts de l'Ordre Sainct Michel, Paris, I550 ? [C. 29. e. 3.]. The other examples, $M$. Moschopuli de ratione examinandae orationis libellus, Paris, I545 [C. 46. h. II.] ; and Petri Bembi Cardinalis Historia Veneta, Venice, I55I [G. 6032.], have the further addition of the crowned $\mathrm{H}$, and the cypher formed by two D's, reversed, and interlaced with an $\mathrm{H}$; together with other attributes of Diane. The recurrence of this cypher, which is sometimes 


\section{4 Bookbinding}

formed by two crescent moons reversed, in place of the D's, not only upon the books of Henri ir., but, also, upon the palaces of the Louvre and Fontainebleau, has given rise to much controversy: and some writers have found in it the cypher of Katherine de Médicis. But there is a passage in a letter of Giovanni Capello, the Venetian Ambassador to the Court of France, describing the first audience given to him by Henri II., which expressly states, that the king had publicly assumed this cypher, in which both the crescent moon and the double $\mathrm{D}$ could be traced, in honour of his mistress, Diane [Armand Baschet, La Diplomatie Vénitienne, Paris, I862, p. 443.]. This, I think, is evidence enough to decide the controversy, were not the device of Katherine de Médicis as distinct as it is, from that of Henri and Diane. In the Queen's cypher, which is always royally crowned, the serifs of the reversed C's extend beyond the strokes of the $\mathrm{H}$; in the disputed cypher, which is never crowned, the strokes of the D's coincide with the strokes of the $\mathrm{H}$.

The hand of more than one gilder may be traced upon the books of Henri Ir., and yet another on those of Diane de Poitiers. But attempts of this kind, to ascribe certain bindings to individual gilders, are very empirical : especially when, as in the present case, no documents have hitherto been discovered concerning the authors of these celebrated bindings. Edouard Fournier, on what authority it does not appear, states, that Jehan Foucault 


\section{French Bindings}

and Jehan Louvet were the two most celebrated gilders of leather, during the reign of Henri ir. We know, that the former gilder was employed by Katherine de Médicis at the Château de Monceaux : but there is no evidence to show, that either of these artists worked upon the decoration of books.

Passing over these details, the bindings of Henri Ir. and Diane de Poitiers appear, in a general view, as various examples of a common manner, and the finest and most characteristic productions of the finisher's art in that age. Fine, no doubt, as this new manner is, it shows less reticence, simplicity and mastery of effect, than are found in the older manner, which preceded it, and from which it is entirely distinct. One cause of this inferiority is to be attributed to an excessive use of curves; and to a consequent neglect of those incomparable decorative effects, which are alone to be produced by a proper contrast of curved, with angular, forms and right lines. An instance of this tendency is to be seen in the magnificent binding, executed for the king, which M. Gruel reproduces in his Manucl, as an example of a painted binding: Philonis Judaei in libros Mosis de mundi opificio historicos de legibus eiusdem libri singulares, Paris, 1552, in which the slight border lines are the only right forms, in the whole of the composition. Again, not only are too many elements introduced into the designs of these bindings, but, also, these elements are, themselves, not always in due relation to one another. 


\section{6 Bookbinding}

A comparison of the copy of the Geographia of Berlinghieri, Florence, $c$. I48o, bound for Henri II., and reproduced by MM. Marius-Michel in La Reliure Française [Pl. v.], with the copy of the third and fourth books of Serlio's work on Architecture, Venice, I540, bound for Grolier, and reproduced by M. Gruel, will illustrate my meaning. The bindings of both books are ornamented by a fillet intricately interlaced. In the binding executed for the Treasurer, the interlacings of this fillet, which is principally worked in right lines, are with great art massed by themselves, and subtly contrasted with the other curved and angular forms of the design. In that executed for the king, the interlacings of this fillet, which is almost entirely worked in curves, form a continuous and intricate border, the principal member of a far less effective design. In the interstices of this border, and in the central panel, are powdered the various cyphers and devices of the king and his mistress: amongst which, the cypher of the reversed D's occurs in no less than three, and the crescent moons in two, different sizes. Spaces are then filled in with figured tools, which have no due relation to one another, nor to the ornament, which surrounds them: and this is especially apparent in regard to the tool of the bow and quiver. Upon the binding of Grolier, on the other hand, every element is of the most simple kind, and in the nicest relation to every other ; while the utmost effect is produced by their proper use and contrast, 


\section{French Bindings}

which cannot be said of the binding executed for the king. This simplicity, unity and proper distribution of the parts, resulting in the most splendid and distinguished effect, go to make up that subtle complexure of qualities, 'architectonice,' to repeat the expression of Goethe, which is the grand characteristic of the Italian genius, in the art of modern Europe : and this it is, which separates such bindings of Grolier, as Italian work, from the French work executed for Henri ir. and Diane de Poitiers. In regard to the actual workmanship of these bindings, it is to be observed, that upon Grolier's binding, with the exception of the lettering and two figured tools, which are used with great judgment and reticence, the whole of the design is worked by means of simple gouges and wheels: while on the bindings of Henri II., not only are a far greater number of figured tools used, but, also, a stamp of arms in the central panel. Again, there is a tendency in these later bindings to produce, by means of gouges alone, forms, which would be better and more easily made by figured tools : as on an elaborate binding of Diane de Poitiers', figured by M. Bouchot in Les Reliures d'Art à la Bibliothèque Nationale [Pl. XLII.].

If I have pointed out that these French bindings are not as perfect works of art, however technically accomplished, as are the finest Italian bindings executed for Grolier and a few other collectors, let me not be thought to underrate the sumptuous 


\section{I 8 \\ Bookbinding}

beauty and historical interest, which they unquestionably possess. The figure of Diane de Poitiers, her charm and fascination, her patronage of such men as Delorme and Goujon, in a great age of art, have justly done not a little to increase the estimation, in which these bindings are held: but it is the part of the critic in such matters, to distinguish between the intrinsic value of a work of art, and the glamour and interest, which time and history have cast over it.

The bindings executed for François II., during his brief reign, are almost as rare, as those executed for his queen, Mary Stuart. They appear to have been finished by the gilders, who had worked for Henri II. ; and we must turn to the books of Charles Ix., who succeeded his brother in 1560 , not only for a new manner, but, also, for a new style. This style, which was adapted from the medieval device of the 'semis,' the repetition of some given figure over a field at regular intervals, continued in use upon the books of the royal libraries, during the following century: and it is in the invention of this style, that French gilding first appears to free itself from the traditions of Italian Art. A remarkable binding tooled in this way covers a book, which was placed in the library at Fontainebleau, by Katherine de Médicis, in memory of Henri Ir., and which is reproduced by M. Gruel, in his Manuel. The 'semis,' with which this book is ornamented, consists in the repetition of two crowned cyphers, the one 


\section{French Bindings}

formed by the $\mathrm{C}$ of Charles Ix., the other of the $\mathrm{K}$ of Katherine repeated and reversed. The Binder in Ordinary to Charles Ix. was Claude Picques, as

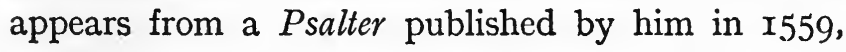
which bears the following imprint: 'Apud Claudium de Picques liguatorem Reg. in vico S. Jacobi, sub signo D. Trinitatis.' Earlier, in $\mathrm{I557}$, he was working for Katherine de Médicis [Bibl. Nat. Ms. fr. r0396.] : and his name occurs again as 'Relieur de Roy,' in 1568, in the Traité de la Peste, of Ambroise Paré, at which time he was still living in the Rue Saint Jacques. The earliest examples of royal bindings ornamented with the 'semis,' in the British Museum, are those executed by Nicolas Evve, for Henri III., who succeeded his brother in 1574 . But before I speak of the work of Nicolas Ève, I will recount what is known about him. The statements, which have come down to us concerning this binder and his family, are not only very confused, but even contradictory: it is impossible to establish any agreement between the accounts of La Caille and Lottin; nor do the assertions of these writers accord with the few facts of undoubted authority, which have been collected. But, in this place, a review of these authentic passages will be more profitable, than an attempt to touch upon errors, or to entangle discrepancies. We gather our earliest information concerning Nicolas Eेve from a book, published by him in 5578 , entitled Traité des Mésaventures des Personnages signalez; being a trans- 


\section{Bookbinding}

lation by Claude Vitart, of Boccaccio's De Casibus Illustrium Virorum. He was then living at the sign of the Adam and Eve, in the Clos Bruneau, Rue Chartière: and in the imprint of this and other works published by him, he distinctly styles himself bookseller and binder, 'Libraire de l'Université de Paris et Relieur du Roy.' There exists, however, a somewhat later, but far more important, document, in regard to his office of Binder to the King, in the following entry of a payment made to him, in 1579 , for binding certain copies of the Statutes and Ordinances of the 'Ordre du Sainct Esprit,' printed at Paris, about that time, for Henri III., which is preserved in a book of the household accounts of that king :

'A Nicholas Ève, laveur et relieur des livres et libraire du Roy, 47 escus et demy pour avoir lavé, doré et réglé sur tranche, 42 livres des Statuts et Ordonnances de l'ordre, reliez et couverts de maroquin orenge du Levant, enrichis d'un costé des armoires de Sa Majesté pleines dorées, de l'autre de France et de Pologne, et aux quatre coins de chiffres, et le reste de flammes, avec leur fermoirs de ruban orenge et bleu, suivant l'ordonnance de M. le chancelier du 26 et quittance du 27 décembre 1579 , cy XLvil escus et demi ' [Bibl. Nat., Ms. Clairambault, I23I, fol. 9I et ro8.].

One of these books, retaining the binding of Nicolas Eve, is preserved in the British Museum [C. 29. k. 3.], and another is in the Bibliothèque 


$$
x=
$$




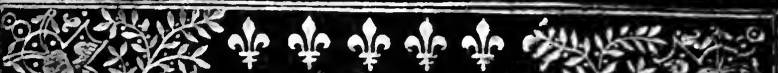

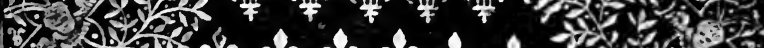

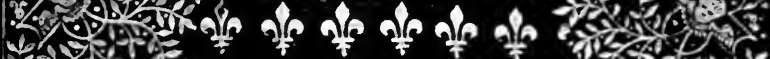

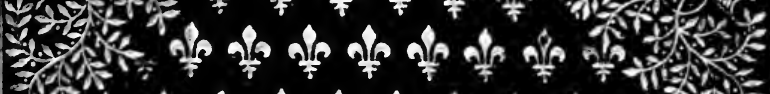

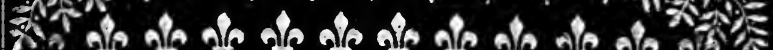

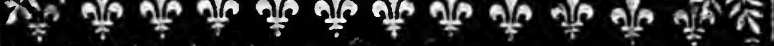

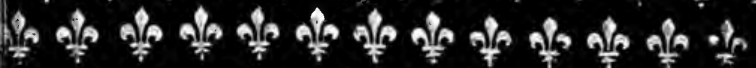

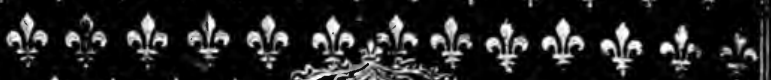

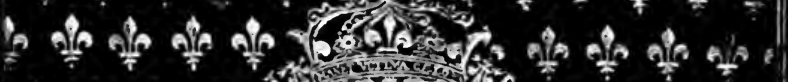
Aै

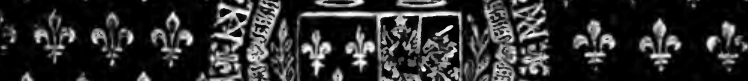
불 (5) ํำ $\frac{1}{7}$ ?

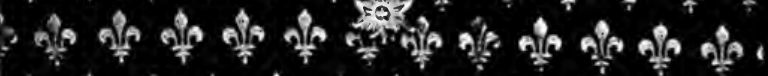

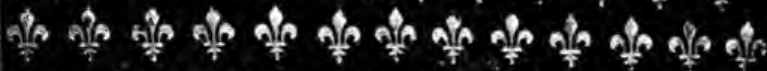

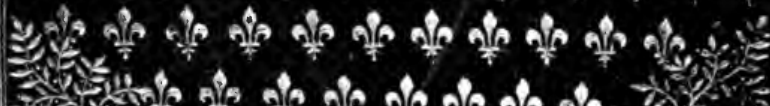

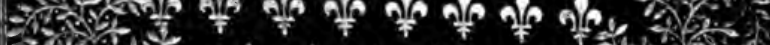
C. 4. 20 .

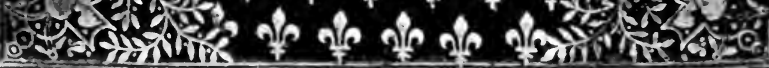

NICHOLAS EVE.

(HORACE, 1581.) 


\section{French Bindings}

Nationale [vide Gruel, s.n.]. In the centre of the upper board are the arms of France impaling those of Poland; on the lower, are the arms of France alone. In each corner of the boards is the crowned cypher of Henri III., and Louise de Lorraine, being an $\mathrm{H}$ interlaced with two $\lambda$ 's : the emblem of the Holy Spirit is repeated four times about the royal arms: and the remaining field of the boards is powdered with a 'semis ' of fleurs-de-lys and tongues of flame. In both copies, the orange morocco has become changed and darkened with time. The British Museum also possesses two other books bound for Henri III., tooled in a very similar manner, which may with certainty be attributed to the binder of the Statutes of the 'Ordre du Sainct Esprit.' The smaller volume, which is figured in Plate vI., is a Horace, printed at Venice, in $\mathbf{I 5 8 I}$ [C. 48. d. 5.] : the larger a copy of Paulus Aemilius' Histoire des Faicts des Roys, Princes, Seigneurs, et Peuple de France, Paris, I58I [G. 6455.].

These bindings, however, are neither those which are commonly associated with the name of Henri III., nor those popularly attributed to Nicolas Eve. The books of this king, to which I allude, are bound after a common model. In them, the field of the boards is divided by a floriated fillet of three lines, into variously shaped compartments, which are left unornamented, except by a central stamp, representing the Crucifixion. The back of the book is broken by a similar fillet: the title is tooled at the 
head; the legend, SPES MEA DEVS, at the tail end; the arms of France in the centre; and in the intermediate spaces are placed a skull and a fleur-de-lys. Henri III. caused his books to be bound with these lugubrious symbols, without regard to their contents ; much in the same way as his public professions of morality were made, without any apparent reference to his private life. The design of these bindings is as little pleasing as their sentiment; the forms of the compartments being ill-contrived in themselves, and without relation to one another. A good example of such a binding may be seen on a copy of the Devotes Contemplations, of Luis de Granada, Paris, 1583 , in the British Museum [C. 47. a. I9.], which, also, possesses another very large, but very mutilated, specimen of the same kind.

The bindings popularly associated with the name of Nicolas Eve, appear to have little or nothing in common with his authenticated binding of the Statuts de l'ordre du Sainct Esprit. A fillet divides the field of the boards into compartments similar in character to those on the bindings of Henri III., which I have just described : but they are generally better contrived, and more delicately tooled. In some examples, this fillet forms the only decoration of the book; as on a copy of the New Testament, in Greek and Latin, Paris, 1565 , in the Museum; the device of Colbert having been added at a later date [676. i. I6.]. The occurrence of these simple bindings may, perhaps, be due to an article in a sump- 


\section{French Bindings}

tuary edict issued by Henri III., in 1577 , which forbade the use of gilding upon books, except ' un filet d'or seulement sur la couverture, avec une marque au milieu de la grandeur d'un franc au plus': the bindings of princely and ecclesiastical personages were alone excepted from this rule.

In other examples, the compartments thus formed, are elaborately filled with branches of palm and laurel, floriated spirals and other ornaments. The total effect of such bindings is rich and harmonious; the masses of the various parts being equally distributed: but upon a nearer view, a large number of elements are found to have been introduced, without proper reference to one another, or to the spaces, which they decorate. One compartment is arbitrarily filled with laurel, the next with some conventional form, the third with the figure of a bird, or flower : that logical sequence of ideas, which forms the basis of all the finest works of art, is here absent. Their workmanship, however, is more accomplished, than that of the books, which preceded them: they are more solidly forwarded ; and their gilding is singularly delicate and skilful. In the British Museum are two books bound in this manner, and stamped with the arms of the President, Jacques Auguste de Thou, Poetae Graeci, Paris, I566 [C. 47. b.], and Valerius Maximus, Antwerp, 5754 [684. c. 29.]; together with a Breviary in folio, Paris, I588, which bears the arms of the Abbey of Marmoutiers [C. 24. d. I.]. An inquiry 


\section{24 Bookbinding}

into the tradition, which attributes these elaborate bindings to Nicolas Ève, establishes little else than the fact, that their style was in vogue, while he was holding the distinguished office of 'Relieur du Roy': his authenticated bindings are in a wholly different manner from that of these rich bindings 'à la fanfare,' as they were fantastically called by Nodier, at the beginning of the last century. M. Thoinan is of opinion, that this style was common to the times; and he recalls the names of the many binders then living, Michel Clopejau, Nicolas Desfossés, Jean de Bordeaux, François du Mays, Michel Gadoulleau, Gilles Gilles and Jean de Heuqueville, who may have employed it, on their bindings.

Somewhat earlier, perhaps, in date, than these elaborate bindings, are certain others similar to them in character, which are finished with azured tools of a larger kind, and have the interlacings of the fillet contrived in a more simple and geometrical manner. This style generally occurs upon books of no great size; as on a copy in three volumes of Dionysii Arcopagitac Opera, Paris, 1562, in the British Museum; the boards of which are painted, in the centre, with the arms of Katherine de Médicis [C. 24. e. 6.].

The date of the death of Nicolas Eve is unknown; but he appears to have been succeeded, in his office of Binder in Ordinary to the King, by George Drobet, who published several works at Tours in 1592, on the title-pages of which he styles 


\section{French Bindings}

himself 'Relieur du Roy.' This stationer had established himself at Paris, before 1596 ; in which place and year, he published a translation into French, of the Divine Comedy, with the imprint: 'Pour George Drobet Libre \& Relieur du Roy, rue S. Jacque au soleil d'or \& en sa boutique au Palais, en la gallerie des Prisonniers.' Drobet was in turn succeeded in his office, by Clovis Ève, unless the place was conjointly held by them; the grant of this title to two persons at the same time, being a common practice, during the next century. Of the early history of Clovis Ève, who was probably a son or nephew of Nicolas Ève, nothing is known : but in 1596 , he published a book of devotions entitled: Le Thrésor des Prières, Oraisons et Instructions Chrestiennes pour invoquer Dieu en tout temps; the imprint of which runs: 'A Paris pour Clovis Ève, Relieur ordinaire du Roy au Mont S. Hylaire,' 1596. Other evidence of his office of Binder in Ordinary to the King, exists in the 'états,' or checkrolls, of the Royal Household, where his name is duly entered from 1598 to 1633 : that for the year I598 being the earliest to which M. Thoinan, my authority, could gain access. He was Master of the Guild of St. Jean, from $\mathrm{I} 602$ to $\mathrm{I}_{60} 4$; and remained one of the most assiduous members of that society in attending its meetings, as the records bearing his signature prove. In 1605 , he published the tragedies of Charles Bauter; but it was with the publication of religious books, that he was 


\section{26 Bookbinding}

chiefly occupied. An Officium beatae Mariae Virginis ad usum Romanum was issued in I608, with the joint imprint of Pierre Mettayer and Clovis Eve : and it further appears, that they, as printer and bookseller, obtained a renewal of certain privileges to print and issue 'Messels, Bréviaires, Diurnaux et autres livres concernans l'usage du Concil '; and that in consequence of the opposition of the Stationers and the University, these privileges were withdrawn, by a decree of the Council, dated 23rd December, I6ri. Pierre Mettayer obtained his freedom, as a master-printer, in 1602: his partner, Clovis Ève, who like Nicolas Ève, was not himself a printer, appears to have died towards the close of the year 1634 , or the beginning of the year I635.

There is no authenticated binding by Clovis Evve: but in a book of household accounts of Gaston d'Orléans, there is an entry of a payment of 33 livres made to this binder, on the I7th June, I628, for binding a Missal and a Book of Hours, in 'maroquin de Levant incarnat semées (sic) de fleurs de lis' [Bibl. Arsenal, MS. 4209.]. Again, there is a binding of an Office de la Semaine saincte, published by Clovis Eve in I6I9, which M. Gruel, who reproduces it in his Manuel, attributes to this binder. It is covered in olive morocco; and, like the Missal and Hours of Gaston d'Orléans, it is tooled with a 'semis,' which, in this case, is composed of the crowned L's and fleurs-de-lys of Louis XIII. 


\section{French Bindings}

The bindings, which have been traditionally ascribed to Clovis Eve, exhibit a very different character : of these, the most celebrated are popularly supposed to have been executed for Marguerite de Valois, the queen of Henri Iv. The field of their boards is broken by a series of ovals, in the centre of which are placed various flowers, or sprigs of oak or pomegranate; the whole being surrounded by borders of palm-branches : the central oval of the upper lid is tooled with a shield, charged with three fleurs-de-lys on a bend; that of the lower cover with the legend, EXPECTATA NON EIVDET. A copy of Caesar, Paris, 1564 , in the British Museum, affords a good example of this kind [C. I9. a. I5.]. It was M. Guigard in his Armorial, who first pointed out, that these arms could not be those of Marguerite de Valois; and, at the same time, suggested, that their bearer might be found in Marie Marguerite de Valois Saint Remy, the daughter of a natural son of Henri III. Tradition has further declared, that Marguerite de Valois herself gave the design for these bindings; a statement equally untenable. It is evident, that this style of the ovals, though probably invented and used by some one binder, was employed by him upon the books of his various patrons: thus, the binding of a Terence, Geneva, I58I, finished in this style, and tooled with the arms of Nicolas de Villars, Bishop of Agen, is figured by Mr. Quaritch among his illustrations [No. 47.]; while amongst similar bindings, stamped with the 


\section{8 Bookbinding}

cyphers of various collectors, in the British Museum, may be cited those of a Latin Psalter, Paris, 1586 [C. 48. e. 4.], and a manuscript of Horae et officia, fourteenth century [Add. MS. I4,845.].

The tools used upon these bindings possess a very distinct character, and may, perhaps, be traced upon other contemporary bindings, which are finished in different styles: as that of a copy of the De rebus Salomonis regis, by Joannes de Pineda, Lyons, r6o9, bearing the arms and cypher of Henri Iv., which is figured by M. Gruel. It is designed in a little manner, and worked without due care : being one of the king's bindings, it not improbably came from the workshop of Clovis Eve. In the British Museum, may be seen another binding executed for Henri IV., which differs greatly from that of the Pineda. It contains a copy of De Thou's Historia sui temporis, Paris, I604 [C. 20. f. II.] : and the arms and devices of the king form its only decoration.

The bindings, actual or reputed, of Clovis Eve complete that middle period of French bookbinding, which began with the reign of Charles IX. Preceded by the Italianate period of François I. and Henri II. ; it appears almost an age of decadence, when compared with the age of Le Gascon and Florimond Badier, which followed it.

With the commencement of the seventeenth century, the number of binders, styles and collectors, rapidly increases; but the work, which is truly excellent, grows, at the same time, more clearly 


\section{French Bindings}

distinguishable amid the mass of what is mediocre, or commonplace. The qualities of stationer, and bookbinder, become gradually disassociated, and recognised as two distinct callings: while binders of repute work for a greater number of patrons. A knowledge of the arms and cyphers, which occur upon the bindings of collectors, is in itself a difficult antiquarian study; and one, that I do not here touch upon, except in so far as it illustrates the history of the binders and their art. In the absence of a more complete work, the Nouvel Armorial du Bibliophile, Paris, I89o, by Joannes Guigard, contains much information upon this subject.

Whereas, in all probability, the elaborate bindings 'à la fanfare,' executed for the celebrated Jacques Auguste de Thou, were done prior to the sumptuary edict of 1577 ; others of a simple character, which formed the greater part of his library, were finished for him subsequently to that enactment. His arms, in an oval, or surrounded by laurel branches with the addition of a few border-lines in gold, compose the entire decoration of their boards ; and his cypher, with the title of the work, that of their backs. At first his own arms occur, with his initials, I. A.D.T. ; and these may be seen on his copy of Joannis Grammatici Philoponi Commentaria in Libros de Anima Aristotelis, etc., Venice, I535, in the British Museum [672. i. 7.]. Upon his marriage with Marie Barbançon, in 1587 , he impaled his arms with those of his wife; and took a new cypher, composed of the 


\section{I30 Bookbinding}

initials of their Christian names, I.A.M. : as on a copy of Appollonii Alexandrini de Syntaxi libri IV., Frankfort, I590, in the Museum [67x. g. Io.]. After his second marriage with Gasparde de la Chastre, the arms and initial of Gasparde replace those of Marie Barbançon; as upon a copy of Phaedri Fabulae, Paris, $16 \mathrm{I} 7$, in the same collection [C. I9. c. 2I.].

These severe, but pleasing, bindings are among the first indications of the simpler, but more effective, modes of decoration, which began with the seventeenth century, and by which the art of the French binder, untranmelled by any Italian traditions, at length found its finest and most original expression, in the so-called styles of Le Gascon. About the year 1622 , the first characteristic style, of the new manner, came into vogue. It consists in relieving either board with a simple panel, formed by a fillet of three, or four, lines, which cross one another at the angles. The panel is further enriched with arms, and the outer angles of the fillet by 'fleurons,' or flowered corner-pieces; while a second fillet, which generally is similar to that of the panel, runs along the margins of the boards. A charming and very interesting example of this kind remains among the Harleian Manuscripts : it is an autograph copy of a tract by Sir Kenelm Digby, which was published at Paris, in 1638 , under the title of ' $\mathrm{A}$ Conference with a Lady concerning Religion' [Harl. MS. 23I2.]. The binding of this little manu- 


\section{French Bindings}

script is of red morocco; and the fore edge is furnished with two leather clasps ending in little shells of silver. One of the lines of the fillet, and the 'fleurons,' or corner-pieces, are worked 'au pointillé,' that is, by a dotted, instead of a solid, line. The panel is stamped with the arms of Sir Kenelm Digby, impaling those of his wife, Venetia, daughter of Sir Edward Stanley: while the back is decorated with a cypher, composed of their initials, K.V.D. This book was probably bound in Paris, in 1636 , shortly after his return to the Catholic Church : his wife had died in 1633 ; and his extraordinary devotion to her memory, is shown in his continued use of these arms and this cypher. During the Troubles, Sir Kenelm took refuge in Paris, and there had his books bound by the most celebrated binders. According to one account, ' his library, being in France, became on his death the property of the French Monarch, under the 'droit d'aubaine.' It was sold by the person, to whom his Majesty gave it, for I0,000 crowns, and was purchased by the Earl of Bristol.' A priced catalogue of this nobleman's library, which commenced selling in London, on Igth April, I680, is in the British Museum [821. h. 3.]. An introductory note to this catalogue states, that its contents consisted 'principally of the Library of the Right Honourable George late Earl of Bristol, a great part of which were the curiosities collected by the learned Sr. Kenelm Digby.'

Of all the anachronisms with which the early 


\section{32 Bookbinding}

history of bookbinding is replete, none is more extraordinary than that which ascribes this style of decoration to Augustin Du Seuil, who was not born until I673, and of whom I shall presently speak: but apart from any discrepancy in point of time, books bound in this way are, without doubt, the work of many binders. M. Thoinan gives in Les Relieurs Frangais [Pl. xvi.] an example in which the figured tools, used on the boards and back, are engraved in solid line. The date of this binding is c. I640: and it is to be remarked that, unlike the richer French bindings of the previous century, the bands reappear upon the back, both of this book, and of the Digby manuscript, as well as upon the simpler bindings of De Thou. Another example of this kind, bearing the cypher of Nicolas Claude Fabri de Peiresc, and the addition of some rich tooling at the angles, and in the centre, of the panel of the boards, is figured by M. Bouchot, in Les Reliures d'Art à la Bibliothèque Nationale [Pl. lxii.]. Peiresc, who had an extraordinary care for books of all kinds, used constantly to employ a bookbinder in his house : and of this practice of his, and of his library, we possess the following accounts, which are among the most valuable documents of this kind, in the early history of bookbinding.

'After he had taken care,' in his youth, Bouchard relates of Peiresc in his funeral oration to the Roman Academy, 'to get from all places the most excellent Books, and to adorn them with gold, purple and all 


\section{French Bindings}

manner of neat and curious workmanship, by such excellent Workmen, as lived in his house; and had diligently perused them all : his greatest care in the next place was to travel all Europe over,' to acquaint himself with both ancient and modern civilisation, ' and from thence carry home as much as he could, to treasure up in his Library.' From these travels, Peiresc, and his brother, brought home with them so great a collection of whatever was rare and excellent, that 'all men, of whatever rank or Nation, that were studious of great and rare things, came thither to see him, and his most renowned Study.' 'Also new things were continually brought him, not only from all parts of Europe, but from Asia, Africa, India, and the new World': and others 'were daily sent him, from choyse men dwelling in the principal Cities and Haven-Towns of those Provinces; who were by him imployed with all their diligence, to procure such things, to his infinite charge and expence. And because those Men, with all their Art and Industry, could not fully satisfie Peireskius, he oftentimes sent others from his own House, into all the Islands of the Ægean Sea, to the Mountain Atho, to Constantinople, Alexandria, and those miserable Reliques of Memphis, and Carthage : who for him, and with his money, should seek to procure, besides other Rarities, chiefly, the ancientest Books in the Greek, Hebrew, Arabick, Persian, Coptick, and $\mathbb{E}$ thiopian Languages.' 'In which practise of his, verily, he seems with a mind truly royal, to 


\section{34 Bookbinding}

have imitated the care of those ancient Kings of Pergamus, and Alexandria ; as also of our France, in the magnificent setting forth of their Libraries. And to this his Shop and Store-house, of wisdom and vertue, Peireskius did not only courteously admit all Travellers, studious of Art and Learning, opening to them all the Treasures of his Library; but he would keep them there a long time, with free and liberal entertainment ; and at their departure, would give them Books, Coins, and other things, which seemed most suitable to their studies; also he freely gave them at his own expence, what ever things they wanted, most liberally: even as to all other learned men, well near, which were absent, and whose names he had only heard of ; what ever he had among his Books or Relicks of Antiquity, which he thought might assist them in their writings, he would send it to them of his own accord, not only without their desiring the same, but many times when they were ignorant of such things.' And, elsewhere, we read of him, in his Life written by Gassend, that 'as often as he was informed of Books newly come forth, he would have many of them, which he would partly keep by him, and partly distribute them immediately among his friends, according as he knew they would like the subject matter thereof. And whether he gave them away, or kept them, he would be sure to have them neatly bound and covered; to which end he kept an industrious Bookbinder in his House, who did exquisitely bind 


\section{French Bindings}

and adorn them. Yea, and sometimes he kept many Bookbinders at once; for one man was hardly ever able to bind up such store of Books, as came trowling in from all parts. Also, it happened frequently, that such Books as he borrowed, being neglected by their owners and ill bound, he delivered to his binder to be rectified and beautified, viz. when their subject matter or rarity deserved that cost; so that having received them, ill-bound, and illfavoured, he returned them trim and handsome. And so he did by all the very old Books which he could get, whether printed or Manuscripts. Nor did his care only extend to such as were entire and perfect; but even to fragments of Books, and leaves half eaten. And being demanded why he would be at that charge in the Bookbinding, he would say, the Cause was, inasmuch as the best Books, when they fell into unlearned men's hands ill-accoutred, were pitifully used; he therefore endeavoured, that they might be prized at least for the beauty of their binding, and so escape the danger of the Tobacconist and Grocer. And those which he bound for his own use, he would have his mark stampt upon them. Which mark was made up of these three Capital Greek letters, $N K \Phi$, which were so neatly interwoven, that being doubled, they might be read to the right hand, and to the left, by which initial capital Letters, these three words were designed, Nicolas, Klaudius, Phabricius' [The Life of Peireskius, Englished by W. Rand, London, I657, 


\section{36 Bookbinding}

Part II., pp. 246, 255, I94.]. Malherbe, in a letter addressed to Peiresc, dated 28th October, I609, writes that he has found for him, apparently at his request, upon the recommendation of one Provence, a bookbinder, a 'gentil garçon,' whose proficiency in binding would not be suspected from his want of a beard [Bibl. Nat., Ms. Lettres de Malherbe à Peiresc, fr. 9535.]. From another passage, also printed by M. Thoinan, of a letter from Peiresc to Gassend, dated Aix, Irth June, I633, it appears, that the binder then employed by this collector was Corberau, probably the Guillaume Corberau, whose name appears in a list of the guild of St. Jean, in I627. The greater number of the books bound for Peiresc, are covered with purple morocco, and are stamped with his beautiful cypher, drawn in a double line, on the boards; while a simple border-fillet and the lettering complete their decoration. An example of this kind may be seen on a book in the Grenville Library : Commentatio explicationum omnium tragoediarum Sophoclis, cum exemplo duplicis conversionis Joachimi Camerarii, Basle, 1556 ; the cypher of Peiresc being repeated on the title page [G. 84II.]. He died in I637, aged fifty-six years.

It appears to me, that in these descriptions of Bouchard and Gassend, we possess a series of documents, which explain many practices of the early collectors, in regard to the choice, preservation and use of their books, which are otherwise difficult to understand. This is especially so, in the case of 


\section{French Bindings}

Grolier. If we conclude, that he, like Peiresc, retained an Italian bookbinder in his house, from the time of his abode in Milan; we may account for the remarkable continuity in the design and workmanship of the bindings executed for him: and if we conclude, that he used his library in the fine and generous spirit of Peiresc, we may account for the numerous copies of the same edition of the same work, which he possessed.

On the binding stamped with the cypher of Peiresc, which is figured by $M$. Bouchot, I have remarked the addition of some rich tooling at the angles, and in the centre, of the panel of the boards. This enrichment was further increased by extending the central portion of each side of the inner fillet, in a circular form, towards the outer fillet; by the addition of other 'fleurons,' at the angles thus formed; and by the elaboration of the centre-piece. The figured tools used upon such bindings were commonly engraved, partly in solid line, and partly ' au pointillé.' This style, of which M. Thoinan gives an example [P1. XVIII.], together with an analysis of the figured tools used on these books, is found upon a great number of the most costly bindings, executed between the years 1625 , and I645. It occasionally occurs after the latter date: but meanwhile it had been used, and refined upon, with extraordinary success, by 'the master of the couped head,' who bound many of his smaller books in this style, for which it is admirably adapted. But before describ- 


\section{38 Bookbinding}

ing his work, I must speak of his personal history, which presents a problem, as confused and uncertain as that of the Eves, or Du Seuil. This master is popularly supposed to be Le Gascon, a personage at one time so mythical, that M. Henri Bouchot even doubted his existence. From documents, which have lately been discovered, M. Thoinan concludes, that he was Florimond Badier : while a less enthusiastic judgment might, perhaps, consider, that the whole question is still undecided.

The earliest document in the history of Le Gascon, appears to be the following entry, in the register of the guild of St. Jean, now preserved in the Bibliothèque Nationale, of certain payments made to him, in the year 1622 :

'Au Gascon, pour une peau de maroquin incarnat pour relier le missel du Concile, in-fol., que la Compagnie du sieur Chappelet et censors ont donné en blanc à la Confrairie . . $4 l$. Ios.

'Pour un sinet pour servir audit missel . $3 l$. Ios.

'Pour une bazane pour une housse audit missel

ol. $7 s$.

It is to be concluded from this entry, that Le Gascon made a gift of his work, in binding this Missal, to the Guild of St. Jean, of which he was probably a freedman, in the same way as Sébastien Chappelet and his partners had of the book in sheets. Some further description of the Missal is to be found in the same manuscript, where it is described, among the other goods of the confrater- 


\section{French Bindings}

nity, as 'bound in purple morocco, tooled in gold (doré à petits fers), and covered by a case of violet sheep-skin.' It was in use until I645, when it was replaced by a new Missal, bound by Gilles Dubois. Other fragments of the history of Le Gascon are to be gathered from the letters of Dupuy and Peiresc. In the beginning of the year I627, Le Gascon having, at the instance of Dupuy, folded, beaten and cut, certain books, that they might the more readily be sent post to Peiresc, at Aix; the latter wrote in complaint to Dupuy, at Paris, that a copy of the Opuscula Bellarmini had been cut to the quick. Dupuy expressed his surprise, that Le Gascon should have committed this error, 'car il est assez scrupuleux'; and Peiresc returned one of the damaged quires, adding some precautions, whereby such fault might, in future, be avoided. From a passage in another letter dated I2 February, I629, and addressed by the same writer to Dupuy, it appears that Le Gascon had bound a copy of Tertullian intended to be sent, by Peiresc, to a certain cardinal in Italy : and in a third, François Auguste de Thou, writing a few days later from Alexandria, to Dupuy, speaks of the binding of an Arabic manuscript, which he had purchased there, adding by the way, 'que Le Gascon s'étudiera d'imiter la dorure.' These are slight evidences; but they are sufficient not only to prove his existence, but to show, also, that he was a binder, as well as a gilder of books, and had, apparently, been 


\section{I $40 \quad$ Bookbinding}

made free of the Guild of St. Jean, before the year I622.

There is no authentic example of his work; but two books exist, which are traditionally said to have been bound by him. The first of these is the famous Guirlande de Julie, in the manuscript of Jarry, which bears the date I64I. According to a note written at the end of the seventeenth century, by $M$. de Gaignères, who at that time possessed the volume, it was bound by Le Gascon: it is now in the possession of the Duchesse d'Uzès. The binding of this book is of red morocco, with a doublure of the same, which, like the exterior of the boards, is enriched by a 'semis' of the letters $I$ and $L$, the initials of Julie Lucine, afterwards Madame de Montausier. There are, also, other books of hers, which are similarly bound, and apparently the work of the same binder; amongst which is a copy of Les Confessions de Saint Augustin, now in the Bibliothèque de l'Arsenal, and reproduced by M. Bauchart, in Les Femmes Bibliophiles de France. A more remarkable binding is that, also traditionally ascribed to Le Gascon, of a volume of prayers, composed by Catherine de Vivonne, Madame de Rambouillet, the mother of Julie Lucine, which is, also, in the manuscript of Jarry. It is bound, like the Guirlande de Julie, in red morocco, bearing a 'semis' of the letter V, interlaced; but the doublure of green morocco is finished in the style of the double fillet, and is of admirable work- 


\section{French Bindings}

manship. This binding is now in a private collection.

It is remarkable, then, that the only examples of binding, which from the time of the seventeenth century have been traditionally ascribed to Le Gascon, should be executed in a manner very different from that, which commonly passes under his name. On the other hand, there is, in the Bibliothèque Nationale, a copy of the De Imitatione Christi, Paris, I640, richly bound in this very manner, and signed 'FLORIMOND BADIER FECIT. INV.' MM. Marius-Michel, in their treatise, La Reliure Francaise, regarded this binding as the work of some inferior imitator of Le Gascon: 'aussi prétentieux qu'inhabile,' they write, 'l'auteur a signé ce volume: Florimond Badier, inv. et fecit, et cela en lettres énormes. Fecit malheureusement; invenit, jamais !' Following M. Gruel, who contented himself by publishing two remarkable facsimiles of this binding, and by insisting upon the importance of Badier's work, M. Ernest Thoinan has now endeavoured to follow out the clue afforded by this signature, and to collect what he might of its author. Florimond Badier, who is thought to have come to Paris from Gascony, was apprenticed to Jean Thomas, gilder, on the zoth November, I63o. The term of his apprenticeship having expired in I636, he married the daughter of Jean Gillede, binder, on the 6th July, I645; and was made free of the Guild of St. Jean, that same year. The date 


\section{I42 Bookbinding}

of his death, like that of Le Gascon's, remains unknown.

The copy of the Imitation, in the Bibliothèque Nationale, which bears the signature of Badier, is bound in red morocco, inlaid with various coloured leathers, in compartments formed by an interlaced fillet. The doublure is of citron morocco, also, inlaid with variously coloured compartments of the same leather, but designed in a style different from that of the exterior, the fillet being omitted. The signature of the binder is stamped on the upper board, above the tail edge of the doublure: and the whole of the figured work is richly tooled 'au pointillé,' that is, not in solid, but in dotted, lines; by which device, an effect of great brilliance and delicacy is produced [Vide, Gruel's Manucl, s.n.]. The execution of the gilding, M. Thoinan contends in opposition to the opinion of MM. Marius-Michel, is unquestionably skilful; although it does not show that solidity and certainty of handling characteristic of the later bindings, which this writer seeks to attribute to Badier: but it is, without doubt, an early production; having probably been executed before Badier was made free of the Guild of St. Jean; and as such, it is a remarkable production, being superior in workmanship to much contemporary gilding.

Tooled upon this binding, along with the signature of Badier, is a couped head, worked 'au pointillé ' like the rest of the figured tools, which 


\section{French Bindings}

is repeated no less than fifty-two times. This head, which is well known from its occurrence upon other bindings, has passed, according to a vague tradition, not only for the mark, but, also, for the portrait, of Le Gascon. Dismissing this tradition as an invention worthy of the predecessors of Edouard Fournier, in the history of bookbinding, M. Thoinan argues, that this head is the mark of Florimond Badier, and that all the bindings, which are tooled with it, were executed by him : and he adds not a little to the force of this argument, when he points out, that the tools used upon the signed binding of the Imitation, occur, also, upon other bindings, both with and without the couped head. In short, not only the bindings, which have been popularly ascribed to Le Gascon, but also Badier's binding of the Imitation, were the production of the same workshop, and were finished with a common set of tools. Further, and of this there can be no doubt, the style of Le Gascon, so-called, was in vogue between the years 1640 , and 1665 : whereas it appears from the records of the Guild of St. Jean, that Le Gascon was a binder of acknowledged accomplishment in 1622 , that is, some twenty years before the style ascribed to him came into use. The most probable solution of this difficult question would seem to be found in the assumption, that Le Gascon was none other than Jean Gillede, whose daughter Badier married, and to whose trade he succeeded. But having concisely stated this vexed 


\section{44 Bookbinding}

question, it will be more profitable, I think, to discuss the bindings themselves, than to attempt to disentangle the discrepancies of their history.

The designs upon these bindings are principally of two kinds. In the more original, the designer, recurring to, and refining upon, the style, which was in vogue at the end of the sixteenth century, and which is popularly associated with name of the Eves, breaks up the field of the boards, by means of an interlaced fillet of three lines, into a series of compartments: and these compartments, he fills with figured work of a conventional character elaborated upon an arrangement of spiral forms, and tooled wholly 'au pointillé,' in place of the former laurel branches, and other ornaments. In some examples, this scroll-work covers the whole field of the compartment; as in the copy of the Paradisus Animae Christianae, Cologne, I644, bound for the brothers Dupuy, and stamped with the couped head, which is figured in MM. MariusMichel's La Reliure Française [Pl. XII.]. The British Museum possesses a very splendid example of this kind, in a copy of Alonso Chacon's Historia utriusque Belli Dacici, etc., Rome, I6I6 [C. I4. c. I2.], bound in red morocco, inlaid with compartments of citron, olive green and brown morocco marbled with black; the colours employed by Badier in his binding of the Imitation. The panels of the back are inlaid and tooled in a manner similar to that of the boards. Among the Egerton manuscripts in the 


\section{French Bindings}

same collection, is a Pontificale, bound in red morocco, and finished with similar ornaments [Eg. Ms. I067.]. This binding bears the arms and cypher of Domenique Séguier, Bishop of Meaux, from I637 to 1658 .

In other examples, the scroll-work but partially covers the field of the compartments: as in the binding of a manuscript, executed by Jarry in 1658 , of Adonis, a poem by La Fontaine, which is figured in MM. Marius-Michel's La Reliure Française [P1. XIV.]; and, again, on the binding of a Book of Hours executed for François I., now in the British Museum [Ad. MS. I8, 853.]. The edges of this volume, which is bound in red morocco, bear a design painted in colours, upon a gold field, and outlined by a series of tooled dots, or points. This method of decorating the edges is characteristic of the richer volumes attributed to Le Gascon: and the edges of the copy of Chacon's History are ornamented in the same way.

Of the second kind, the style of double fillet, to which I have already alluded, a rich example, a copy of Joannis Cassiani Eremitae, bound for Sir Kenelm Digby, is figured by MM. Marius-Michel in La Reliure Française [Pl. x.], and another of a simpler character, in the British Museum, covers a New Testament in Greek, Amsterdam, I633 [675. a. 20.]. The edges of this little volume are marbled under the gold : while the end-papers, covering the boards, are of marbled, and the fly-leaves of white, 


\section{46 Bookbinding}

paper ; an arrangement common to many books of this period. Like the other productions of this master, and unlike those earlier bindings from which their general design is copied, books tooled in this style have the whole of their figured tools engraved ' au pointillé.' These tools, of which the design may have been suggested by metal filigree work, are of an uniform character ; and, from their nature, always appear as detail, subordinated to the chief lines and masses of the composition, in which they occur. In this, lies their peculiar excellence ; extraordinary care and thought being always shown in the design of the geometrical framework to which they are applied, especially when this framework consists of the interlaced fillet. The figures and disposition of the compartments thus formed, the application of the subordinate ornament, and the due relation of every one part to every other, is contrived and executed with incomparable felicity, and in a most distinguished taste. In these bindings, the courtly styles of France have their climax ; brilliant, exquisite and of extraordinary accomplishment; yet worthy to go in paragon with the more virile and scholarly art of the finest Italian binders of the first half of the sixteenth century. The perfection of finishing distinguishes this age of French binding; as that of forwarding distinguishes the succeeding one.

Clovis Ève was succeeded by Macé Ruette, as Binder in Ordinary to the King. It appears from 


\section{French Bindings}

records, that he was the son of one Michel Ruette, ' chargeur de bois au port de l'Escale de Saint Germain l'Auxerrois,' and that, on 5th March, I598, he was bound apprentice for the term of four years to Dominique Salis, stationer and bookbinder, living in the Rue Saint Jean de Latran. According to La Caille, 'c'est Macé Ruette, qui a trouvé l'invention du papier marbré, et du Marroquin jaune marbré,' [Histoire de l'Imprimerie, Paris, I689, p. 213.] : but the first statement is as improbable, as the second is indefinite. I have already touched upon what seems to be the origin of marbled paper. Macé Ruette was master of the Guild of St. Jean, from I629 to 1634 : he was still working for the king in I638, but had died before the year 1644 . One of his bindings may, perhaps, be seen on a copy of Ammianus Marcellinus, Hamburg, I6o9, in the British Museum, the boards of which are tooled with the arms of Louis XIII., and a 'semis' of crowned L's, and fleur-de-lys [G. 9II6.].

Antoine Ruette, the son of Macé Ruette, by his wife, Marie Saminiati, was born 5th February, I6og, and received the freedom of the Guild of St. Jean in the quality of a stationer, on the 9th July, I637. Upon the death of his father, he succeeded to the office of Binder in Ordinary to Louis XIV., as appears from the title of a book, which he published in 1644: L'Office de la Semaine Saincte. A Paris, Chez Anthoine Ruelte, relieur ord. du Roy, rue sainct Jean de Latran denant la fontaine S. Benoist. He 


\section{48 Bookbinding}

was confirmed in the office, by a royal breve dated 3rd July, I65o, receiving at the same time, the grant of a lodging for life in the Collège Royal: and as Binder in Ordinary to the King, he was paid a wage of a hundred 'livres' a year. $\mathrm{He}$ published, also, some other books, either without date, or with that of the year I66r. The binding executed by him, for Anne of Austria, of a copy of his own edition of L'Office de la Semaine Saincte, is reproduced by M. Gruel in his Manuel [s.n.]. It bears the arms of the Queen regent, surrounded by her widow's cords, and her cypher, composed of the letters $\mathrm{A}$ and $\mathrm{V}$, interlaced, and royally crowned. Another example of his work is preserved in the British Museum, on a book entitled : La Lyre du Jeune Apollon, ou la Muse naissante du petit de Beauchasteau, Paris, I657 [84. f. I4.]. This is the copy presented to Louis XIV., to whom the book is dedicated, and whose arms may still be traced below the cypher of George III., which has been stamped over them. The book is covered in green morocco, with a 'doublure' of red morocco : and the tools used on the outside of the book are engraved chiefly 'au pointillé'; while those on the inside are in solid line.

These books show, that their gilder, while actually working according to the traditions, which preceded those of the master of the couped head, was nevertheless greatly influenced by the work of that inimitable artist; to whom, he himself is vastly 


\section{French Bindings}

inferior, both in regard to the design, and to the execution of his bindings. The chief interest of his work lies, perhaps, in the fact, which it illustrates, that the finest productions of the art, at any one period, are not invariably to be found among the royal bindings of that time. La Caille, I may add, speaks of Jean Cusson, who was made free of the Guild, in I630, as the most accomplished binder of this age.

Antoine Ruette appears to have been succeeded, as Binder to the King, by Claude le Mire, whose name appears neither in the registers of the Guild of St. Jean, nor in the works of La Caille or Lottin. $\mathrm{He}$ is first mentioned in the check-roll of the officers of the Royal Household, for the year I664; and it would seem, that he held this office, conjointly with Gilles Dubois, until his death in 1698 , when he was, in turn, succeeded by Luc Antoine Boyet. In r684, this celebrated binder was living in the Rue des Sept Voies : at which time, as it would seem, he had already been made free of the Guild of St. Jean. Later, in I692, his house was in the Cour d'Albret. About the year I698, Boyet became much entangled in the disputes, which were then disturbing the Guild: and he was one of those, who opposed the indiscriminate grant by the Wardens of its privileges ; while he, in turn, was taxed with having obtained his own freedom by favour. The royal breve appointing him Binder to the King, in the place of Claude le Mire, is dated 23rd November, 


\section{50 Bookbinding}

1698. He died in his house, in the Rue du Mont Saint-Hilaire, on the 22nd February, I733.

From notices, which the Baron Jérôme Pichon has collected in his Vie de Charles Henry, Comte d'Hoym, Paris, I88o, it appears, that Boyet worked not only for that nobleman, but also for Du Fay, De Selle, the Abbé de Rothelin, Bellanger and Fléchier. His excellence as a binder lay in his forwarding, which was remarkable for its finish and solidity. He did not sign his bindings : and those which have been attributed to him, are very plainly finished. Indeed, it has been doubted, whether he himself gilded the books, which he forwarded. He is generally believed to have covered many books, with what are known as Jansenist bindings. These bindings are without any gilding, or other ornament, on the exterior, with the exception of a blind fillet; and are so called, from the severity of their style, in allusion to the sect of the Jansenists, which had then not long been formed. Books bound in this way, have commonly a 'doublure,' which is often richly tooled; as in the case of certain bindings executed for Madame de Chamillart, and commonly ascribed to Boyet. These are generally covered in black morocco, with a 'doublure' of red morocco, tooled in gold with a 'dentelle' border, and stamped with her arms. Edouard Fournier, who is no very reliable authority, also, states, that Boyet worked for Baron de Longepierre. Padeloup le jeune is, also, said to have worked for this col- 


\section{French Bindings}

lector: but among his books a few 'reliures doublées' are occasionally met with, which possess all the characteristics attributed to Boyet, by whom they were probably bound; although they cannot with any certainty be assigned to him.

Hilaire Bernard de Requeleyne, Baron de Longepierre, was born in 1659 , and early manifested an extraordinary inclination towards learning. $\mathrm{He}$ became tutor successively to the Comte de Toulouse, and the Duc de Chartres; and was afterwards retained about the persons of the Duc d'Orléans, and the Duc de Berry. He died in I72I. Although he attempted the composition of poetry, and wrote several tragedies, of which his Medea attained to a certain fame, during his life-time, he is now chiefly remembered as a collector of books, which he caused to be bound according to a scrupulous taste, and tooled in gold with the device of the Golden Fleece, in allusion, it is said, to his play. This device, placed at the angles, and in the centre, of the boards, and again in each panel of the back, forms with the title, and occasionally a simple fillet, or roll, the entire decoration of his books, which are all bound after this common model. The charm of these bindings depends not a little upon the taste and judgment, shown in the choice of these simple elements : for more elaborate gilding, would have detracted from the appearance of the forwarding, in which their chief beauty consists. They are usually covered with morocco, and have gilt edges 


\section{52 Bookbinding}

and marbled end-papers. A copy of Longepierre's own translation into French of the Idyls of Bion and Moschus, Paris, I686; bound for him in red morocco, with a green 'doublure'; was sold at the Didot sale in 1878 , as the work of Boyet: and in the British Museum is a little Claudian of Elzevir's printing, I650 [673. a. I4.], which is similarly bound. The 'doublure' is tooled with a 'dentelle' border, and the device of the Golden Fleece: while the edges are marbled under the gold. The occurrence of this 'doublure,' the singular beauty of the colour and texture of the leather, the exquisite finish and solidity of the forwarding, all appear to favour the supposition, that this binding is the work of Boyet. Whether it be so or not, it is, certainly, among the most beautiful and characteristic bindings of his time.

Gilles Dubois, who held the place of Binder to the King, conjointly with Claude le Mire, appears from the accounts of the Royal Household, to have been appointed to that office in 1648 . He is said to have worked for Cardinal Richelieu : and he it was, who gave the Missal to the Guild of St. Jean, which replaced that bound by Le Gascon. He died in I67I, and was probably succeeded by Louis Joseph Dubois, who certainly held the office of Binder to the King, before the year 1707 , and who, in turn, died and was succeeded by the famous Du Seuil, in I723. The name of the latter has been associated, in an unintelligible manner, as I have already observed, with a style, which was in vogue half a century 


\section{French Bindings}

before the date of his birth. Apart from this strange anachronism, his history is of especial interest to Englishmen, for he is the one French binder, who figures in the classics of our literature. In the fourth of the Moral Epistles, addressed by Pope to Richard Boyle, Earl of Burlington, and first printed in I73I, under the title of 'False Taste,' there occurs the following passage, in satire of the affectation, which studies to collect books, rather than to read and understand them :

In books, not authors, curious is my Lord;

To all their dated backs he turns you round;

These Aldus printed, those Du Sueil has bound.

The fame of Du Seuil in England, at that time appears to have been occasioned by the sale of two important libraries in 1724 ; in which a great number of volumes were of his binding. Copies of the catalogues of both these sales are to be found in the

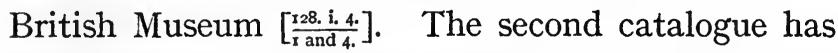
been known to, and discussed by, every writer upon Du Seuil, since Dibdin; but I do not remember to have met with any allusion to the earlier one. It is entitled: 'A Catalogue of the Library of the most Illustrious Henry Marquis de la Bazoniere, Governor of Bayeux in Normandy . . . which will begin to be Sold very Cheap (the Price mark'd in each Book) at James Woodman's and David Lyon's Shop in Russel-street, Covent Garden, on Monday the First of February, I724.' This library contained 'an entire set of the Old Elzivir Classicks in Fifty Volumes,' 


\section{54 Bookbinding}

and 'several hundred Volumes in Folio, bound in Morocco by the Abbé Du Seuil.' The title of the second catalogue runs thus: 'A Catalogue of the Library of his Excellency Louis Henry de Lomenie, Count de Brienne, Secretary of State to Louis XIV. and Ambassador at Rome, belonging to his Son the late Bishop of Coutance in Normandy . . . which will begin to be Sold very Cheap (the Price marked in each Book) at James Woodman's and David Lyon's shop in Russel-street, Covent Garden, on Tuesday 28th of April, I724.' The title adds, that the collection contained 'several hundred Volumes in Folio, bound in Morocco by the Famous Abbe du Sueil.' In both these catalogues, the Latin, French and English books, bound by Du Seuil, are severally described, as: 'Corio Turcico, compact. per Abbatem du Sueil'; 'Relie en Maroquin par l'Abbe du Sueil,' and occasionally, 'dore \& marbre sur Tranches'; or, 'Bound in morocco by the Abbe du Sueil,' and occasionally, 'gilt and marbled on the leaves.'

According to Charles Nodier, 'Du Seuil devait être un ecclésiastique du diocèse de Paris, qui exerçait la reliure en amateur.' But the only binder of this name, of whom any account has come down to us, despite the research which has been made into this matter, is Augustin Du Seuil, the son of Honoré Du Seuil and Isabeau Billonne, who was born at Meounes, in Provence, in 1673. No account has been preserved of his early years, or of his coming to 


\section{French Bindings}

Paris : but it is thought, that he was apprenticed to Philippe Padeloup, the elder ; since he was married, on 23rd November, I699, according to the register of St. Séverin, to Françoise, the daughter of that binder, and a first cousin of the celebrated Antoine Michel Padeloup. She bore him seven children, and died on I6th February, I7I4. In the certificate of her death, he is described as ' Relieur de Monseigneur et de Madame la Duchesse de Berry': at this time he lived in the Rue Saint Jacques. By a breve dated 26th February, I7I7, he was appointed by Louis Xv., at the instance of the Regent, father to Madame de Berry, one of the Binders in Ordinary to the King. Both Luc Antoine Boyet, and Louis Joseph Dubois, enjoyed at that time the title of 'Relieur de Roi': and the grant of it to Du Seuil must be taken as a mark of especial favour, for at no one time had it previously been conferred upon more than two binders. By a second breve, dated I5th February, I728, Du Seuil was appointed by the king, 'en la charge de l'un des relieurs de sa maison,' vacant by the death of Louis Dubois ; an office which Du Seuil held until the time of his death in February, I746. It is remarkable, that the name of Du Seuil occurs neither in the lists, nor in the registers, of the Guild of St. Jean, nor in any other connection with that society.

No authenticated example of his work is known : but certain books from the library of Madame de Berry are thought to have been bound by him. M. le Baron Pichon possessed a volume of prayers, 


\section{56 Bookbinding}

which belonged to her, and which he believed to be an undoubted example of Du Seuil's work. It was covered in citron morocco, on which the arms and cypher of its owner were tooled in blind; with a 'doublure' of red morocco finished with a 'dentelle' border in gold. The same writer in his life of Comte d'Hoym shows, that Du Seuil worked for that nobleman, as well as for the Abbé de Rothelin, and for De Selle, amongst other distinguished collectors of that time.

With regard to the books of the De Loménie library, which are stated, in the catalogues of Messrs. Woodman and Lyons, to have been bound by the 'Abbé du Seuil'; arguments have not been wanting to show, that the word 'Abbé' is merely a misreading, on the part of the English compiler of this catalogue, of 'Au.', or, perhaps, the initial, A ; and that Augustin Du Seuil is intended. On the other hand, it has been urged, that this binder could not, in point of time, have worked for De Loménie, who died in 1698. According to the 'Mémoires inédits de Louis Henri de Loménie, Comte de Brienne,' published in 1828 , by $\mathrm{F}$. Barrière, the Count gave his books, during his life-time, to his son, the Bishop of Coutances: and among the Harleian manuscripts [No. 4638.] is the catalogue of his printed books, containing the original deed of this donation, dated I 3 th January, I670: and an introductory note to the catalogue of Messrs. Woodman and Lyons, states, that the library sold by them, 


\section{French Bindings}

' was chiefly collected by the famous Father Simon, the best Critick in Books in his Time, who was Præceptor and an intimate Friend to Francois Lomenie de Brienne, late Bishop of Coutances in Normandy.' There does not, however, appear to be any ground for the supposition that the collection and re-binding of these books ended abruptly with the gift of them, by Louis Henri de Loménie, to his son. Of the fame of Du Seuil, and of the demand for his bindings, at the time of Messrs. Woodman and Lyons' sales, we have, upon the other hand, sufficient evidence : and the discovery of this second catalogue of the Marquis de la Bazonière's library, issuing from the same source, in which several hundred volumes, bound by the 'Abbé du Seuil,' are prominently set down, tends to raise, rather than allay, suspicion in the matter. Regarding the association of the name of Du Seuil, with the style of the double fillet, which first came into use c. I622, no explanation, however empirical, has yet been attempted.

Antoine Michel Padeloup, commonly called, Padeloup le jeune, who succeeded Luc Antoine Boyet as 'Relieur de Roi,' came of a family, which could boast five successive generations of stationers and bookbinders. Of these, Antoine Padeloup, the grandfather of Padeloup le jeune, obtained his freedom as a master-binder, in I633; and François Padeloup, of the fifth generation, was still working at the beginning of the last century. Antoine Michel Pade- 


\section{8 \\ Bookbinding}

loup was born on 22nd December, 1685, and served his apprenticeship with his father, Michel Padeloup. Before the year I7I2, he had married Marguerite Renault, and had established himself as a masterbinder. It was his practice to affix a small engraved, or printed, ticket, either to the title-page, or the end-papers, of the books bound by him: and on one of these, which occurs in a book printed in I733, Carte générale de la Monarchie francoise, he styles himself 'Relieur ordinaire du Roy de Portugal' [Gruel's Manuel, s.n.]. At this time he was living in the Place de Sorbonne. The breve, appointing him Binder in Ordinary to Louis XV., in the place of Luc Antoine Boyet, is dated 23rd August, I733: this office, he held conjointly with Augustin Du Seuil, who had married his cousin, Françoise. In I735, Padeloup was elected one of the Wardens of the Guild of St. Jean, of which he was an active member. His first wife, who bore him a numerous family, having died; he married, for a second time, in I75I, Claude Perrot, a girl of nineteen, by whom he had six children. His own death occurred on 7 th September, 1758 .

Padeloup le jeune was much employed, not only by the king, but by all the chief collectors of his age : and his practice, of attaching his ticket to the books, which he bound, often enables his work to be recognised with certainty. In the skill, and taste, with which he forwarded his simpler bindings, he belongs to the age of Boyet, and completes the art of the 


\section{French Bindings}

seventeenth century. His work, in common with that of the distinguished forwarders, who preceded him, is remarkable for its solidity, pliantness, finish, and for the beauty of the leathers, which are employed in it. A copy of an Eutropius, etc., Paris, I539, in the British Museum, bound in blue morocco, and stamped with the arms of Comte d'Hoym, is a good example of his art, in this regard [674. a. I4.]. At the foot of the title-page of this little book, is pasted his ticket, engraved with the inscription: 'Relié par Padeloup le jeune, place Sorbonne a Paris.'

In his gilding, in his elaboration of the 'dentelle' border to which he gave a very original air, he may be considered the father of the French binders, who immediately succeeded him; all of whom are inferior to him, both in the execution, and in the invention, of their work. 'Dentelle' borders, so called from the indented edge, which they present toward the centre of the boards, first occur upon the 'doublures' of the time of Boyet: these were now elaborated and used by Padeloup as the chief exterior decoration of the boards. The invention, which he exhibits in the design of these borders, is shown in a binding of great beauty and originality, figured by M. Gruel in his Manuel [s.n.] : the book is a copy of Les Fêtes données au Roy à Strasbourg en $\mathrm{I744}$, and was bound for Louis xv. Although the forms of the tools, used on this binding, are of a florid character; yet the effect of their composition is at once 


\section{I60 Bookbinding}

simple and magnificent. It is the work of a distinguished artist, the inventor of an individual style. With his inlaid bindings, Padeloup had less success : many are of a geometrical character ; and although executed with great accomplishment, appear mechanical and unpleasing in effect. An example of this kind, an Office de la Semaine Sainte, Paris, I7I2, in the British Museum, has been, with some show of probability, attributed to him [C. 48. d. I4.].

Towards the first half of the eighteenth century, bookbinding rapidly degenerated in France: and little remains to be noticed for its artistic value. Augustin Du Seuil was succeeded by Pierre Anguerrand, as Binder in Ordinary to the King ; and Padeloup le jeune, by Pierre Paul Dubuisson, who was both binder and gilder, and who added to his other accomplishment, a skill in Heraldry, publishing an Armorial, in 1757. Louis Douceur, who held the office of 'Relieur pour le service du dépôt des affaires étrangères,' worked somewhat in the manner of Padeloup le jeune; but his designs want distinction, and his workmanship refinement. He died in 1769 .

The taste for inlaid bindings continued during the greater part of the eighteenth century. Those stamped with the name of Monnier, have been especially sought after by modern collectors : they are probably the work of Jean Charles Henri le Monnier, binder to the Duc d'Orléans, who received his freedom in 1757. These bindings are executed with extraordinary accomplishment: but they are such 


\section{French Bindings}

as would become a boudoir, rather than a library. The British Museum possesses an unusually fine example, La Sainte Bible, Cologne, I739, the boards of which are inlaid with flowers: on the lower cover occurs the name MONNIER, in gold letters [C.46.c.30.]. The total effect and colour of this binding is, certainly pleasing : but the forms of the decoration are ill conceived, and worse drawn. Other bindings by Le Monnier, one of which, executed for the Duc d'Orléans, is reproduced by M. Gruel, are designed in the 'Chinese taste' of the last century; further than which, absurdity cannot go. An earlier binder, who produced many inlaid bindings, was Jacques Antoine Derome, who received his freedom in I7I8, and died in I760. In the Museum is a binding of this sort attributed to him, Heures Nouvelles, Paris, I749 [C. 48. b. 8.]; and other examples are figured by MM. Marius-Michel in La Reliure Française [Pl. XVIII. and XIX.].

Of the numerous binders, which the two branches of the family of Derome produced during the eighteenth century, by far the most celebrated was Nicolas Denis, known as Derome le jeune, the third son of Jacques Antoine Derome. Born in I73I, he received his freedom in $176 \mathrm{r}$, and died about $\mathrm{I} 788$. $\mathrm{He}$ is the only binder of his time, who achieved the invention of an individual style: which he did in his 'dentelles à l'oiseau.' These 'dentelles' have been thought to rival those of Padeloup; and they certainly possess a distinct and pleasing character of 


\section{I62 Bookbinding}

their own : but Derome was a very inferior workman to Padeloup. The 'sin of cropping' lies heavy upon him: he ruthlessly ploughed the margins of the finest books entrusted to him ; and freely used the saw to embed his cords, that he might indulge the consequent vice of a hollow back: but these, it must be remembered, were sins of commission common to the age in which he lived. Derome's business was carried on by his nephew, Alexis Pierre Bradel, after his death. Of the binders contemporary with him, the most noted were Pierre Vente, Jean Pierre Jubert and François Laferté.

With the Revolution, fine binding, like every other fine art, was brought, for a time at least, to an abrupt end : and the traditions of good workmanship were not revived until the beginning of the last century. At first, the celebrated Thouvenin, with Bozérian, Purgold, Lessée, who extolled his art in verse, and disputed with Dibdin, and later, Bauzonnet, Trautz, Cuzin, Thibaron, Lortic, Niédrée, Duru and Capé, laid the foundations of the present school of French bookbinding. Examples of the work of Thouvenin, Bauzonnet and some others may be seen in the British Museum : while the productions of the more recent school may be found well illustrated in M. Octave Uzanne's work, La Reliure moderne, artistique et fantaisiste, Paris, I887. The technical accomplishment of this school is very extraordinary : but its want of invention, of a sense for decoration; in short, of power to understand, 


\section{French Bindings $\quad 163$}

and put to fine uses, the genius of the art, is yet more remarkable. 'Productions are now possible,' says Goethe, 'which, without being bad, have no value. They have no value because they contain nothing; and they are not bad, because a general form of good workmanship is present to the author's mind.' 


\section{CHAPTER IV}

\section{ENGLISH BINDINGS}

THE art of gold-tooling was not introduced into England, until more than half a century after it had been brought into use at Venice. It appears to have been first employed here, in the workshops of Thomas Berthelet, the King's Printer and Stationer, who dwelt 'nere to the condite at the signe of Lucrece,' in Fleet Street. He was the third, in succession to Faques and Pynson, who had the honour of being made King's Printer : and his patent granting him an annual fee of 4 l. sterling, in that office, is dated 22nd February, I530. In Brewer's State Papers of Henry virI., several documents are to be found calendared, which relate to books bound for the king, by Berthelet : but of such evidences, the most important is a bill of his, for proclamations printed, books bound, and stationery supplied to the king's use, during the years, I54I, I542 and 1543. Attached to the bill, which is in the form of a paper book of twelve leaves, is a warrant under the sign manual of Henry virr., addressed to Sir Edward North, the treasurer of the Court of Augmentations, directing payment to be made to Berthelet of 'the Somme of one hundred Seventene I64 


\section{English Bindings}

I 65

poundes sixe pence and one halfepeny sterlyng,' the amount of the bill. The original document, which has been printed by Mr. Arber in his transcript of the Register of the Stationers' Company [London, 1875, vol. ii. p. 50.] is now preserved among the Additional Manuscripts in the British Museum [No. 28, 196.].

The designs on the gold-tooled bindings of Thomas Berthelet, were avowedly imitated from the various styles then in vogue throughout Italy: and in this bill, we find books described as being ' bounde after the Italian fascion,' or ' after the fascion of Venice.'

Others are mentioned as being 'bounde in crymosyn satyne,' 'couered with blacke velvet,' or ' gorgiously bounde and gilte on the leather.' One entry I will give at length as a specimen of the rest : 'Item delyvered vnto the Kinges highnes, the $\mathrm{xv}$ day of January a New Testament in latyne and a psalter englisshe \& latyne bounde backe to backe in white leather gorgiously gilted on the Leather: the bookes came to $\mathrm{ij}$; the byndying and arabaske drawyng in golde on the transfile, iiijs. Summa vjs.' None of the books described in this bill, have as yet been identified with any volume remaining out of Henry viII.'s collection : but a copy of Sir Thomas Elyot's Image of Governance, printed by Berthelet in I54I, and retaining its original binding, is preserved among the books of the Old Royal Collection [C. 2I. b. 7.]. The binding of this book, which answers to that of the New Testament and Psalter, described in the 


\section{66 Bookbinding}

foregoing passage, was, in all probability, executed by Berthelet for the king. It is covered in white leather, probably doeskin, and richly tooled in gold with arabesques, surrounded by a border with flowered pieces at the angles; and each cover bears the initials H. R., with the legend DIEV ET MON DROIT : the edges of the book are lettered in gold, with the words REX IN ETERNVM VIVE. The figured tools used in gilding the boards, are of that solid Venetian character, which is popularlyassociated with the name of Aldus : indeed, were it not for a peculiar handling of the tools, it would, in the present instance, be difficult to distinguish between the ornaments used upon this book of Berthelet's, and those, which occur upon certain contemporary Italian bindings. That foreign gilders were in the employment of the King's Printer, is improbable, notwithstanding these and other peculiarities of design and handling. Another book printed by Berthelet in 1534, Opus eximium de Vera Differentia Regiae Potestatis et Ecclesiasticae, and apparently bound by him, remains, also, in the Old Royal Collection [C. 24. a. 25.]. It is stamped with the arms and supporters of the king ; but the gilding has, unfortunately, been freely re-tooled, and much of its interest thereby lost. Several volumes, however, are preserved, in a finer condition, among the manuscripts of the Royal Library, the bindings of which are very similar in the manner of their design and execution, to the bindings of these books printed by Berthelet: and in 


\section{English Bindings}

the absence of any precise information about them, they may, not without reason, be also attributed to him. Of these manuscripts, the chief is a treatise inscribed to King Henry vill., in I544, by Anthonius de Musica; and entitled, Commentaria rerum ab Imperatore Carolo gestarum apud Sanctum Digerium [Royal Ms. I3, B, xx.]. The arms of the king, and the initials H. R., are tooled in the centre of either cover, with a label repeated above and below, on which the following inscription is carried: 'VERO DEFENSORI FIDEI' 'ERRORVMQVE PROFLIGATORI OPTIMO' 'MAXIMO HENRICO OCTAVO' 'REGI ANGLORVM FRANC. HIBERNIEQVE P. M. P. P. D. G.' The whole is surrounded by two enriched border fillets of gold and blind work; and in the remaining spaces are repeated the heads of Plato and Dido, in medallions. Another Latin treatise, Libellus de Tribus Hierarchijs, also addressed by its author, Gualterus Delaenus, to Henry, is covered, like the former, in brown leather: the arms of the king, together with the type and antitype of the crucifixion and the brazen serpent, are tooled in gold within a panel, formed by an oblong fillet interlaced with another of a lozenge form ; and the remaining spaces are filled with small cornucopias, roses, and other ornaments of a Venetian character [Royal MS. I2, B, xiij.]. On a third manuscript, Julij Claudij Iquini Oratio ad Hen. viij, ad faciendam expeditionem in Turcas hortatoria, the arms of the king occur in a panel surrounded

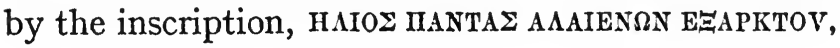




\section{I68 Bookbinding}

and contained within a blind fillet, enriched with figured work in gold [Royal Ms. I2, A, lxiij.]. Of the embroidered bindings executed for Henry virr., there are in the British Museum, a Bible in Latin, printed at $Z$ urich, in $\mathrm{r}_{543}$, bound in purple velvet, and embroidered with a design in outline, and the initial H. R., in gold thread [C. 23. c. 3.], and a manuscript, Description de toute la Terre Saincte, by Martin de Brion, which is, also, bound in crimson velvet, but heavily embroidered, in gold and coloured silks, with the arms of England surrounded by the garter, crowned, and the initial $\mathrm{H}$. repeated in the centre, and with roses at the corners, of either board [Royal MS. 20, A, iv.].

Although the sole right of printing the Statutes and Proclamations was granted to Richard Grafton, upon the accession of Edward vi., Thomas Berthelet continued 'the King's printer seruaunt,' as appears from an entry among the Trevelyan papers, published by the Camden Society, of a reward, or gift, to him of 6s. 8d. on New Year's Day, 1548. At this time, Rainer Wolf, who had been printer to Henry viIr. for Latin and Greek, was the King's Stationer. Berthelet, however, would seem to have furnished that prince with bindings, both before and after his accession to the throne. The gilding upon a manuscript, In Trogum Pompcium sive Justinum, ct in Epistolas familiares Ciceronis, Chorographica, presented by the author, Petrus Olivarius, to Prince Edward in 1546 , is worked entirely in Berthelet's 


\section{English Bindings}

manner, with solid tools of a Venetian character : the Prince of Wales' feathers in a crown, with the initials E. P., and the legend ICH DIEN, upon a label, surrounded by a flamed circle, are repeated on either board [Royal MS. I5. C. i.]. A second manuscript, a translation into English by William Thomas, who dedicates his work to the king, of a book of travels entitled, Here beginne the thinges that were seen and hearde by me Josaphat Barbaro Citizen of Venice in twoo voiages that I made thone vnto Tana and thother into Persia, also, retains its original binding. Two fillets are carried about the board, at some distance from one another, so as to form a panel ; the inner fillet is interlaced with another of a lozenge form, and the panel is ornamented with the arms of England in a flamed circle. Both the fillets and the circle are painted black: and the intermediate spaces are tooled in gold, with Venetian scroll-work [Royal MS. I7. C. x.]. The binding of a third manuscript, Gualteri Deloeni Commentarius in 3 prima Capitula Geneseos Regi Edwardo vj, pro Strena datus, is less satisfactory in regard to the design. The arms of the king are repeated in the centre of each board, with a crowned rose above; and the initials E. R., with the badge of the Daisy, upon either side : while a kind of cornucopia is repeated some six times, with no very great art, about the panel, which is formed by a plain-gilt fillet, with fleurons at the angles [Royal MS. 7. D. xx.]. Among the printed books of the Old Royal Collection, is a copy of Car- 


\section{I $70 \quad$ Bookbinding}

dinal Bembo's Historia Veneta, Venice, I55I [C. 24. c. 20.] ; the binding of which is tooled by Berthelet with a design, finer, perhaps, than any, which I have as yet described. The field of each board is broken into various circular and quadrangular spaces, by an interlaced fillet, painted black: the arms of England are tooled in the central compartment, with the motto DIEV ET MON DROYT above; the date $M \cdot D \cdot L \cdot I I$, below ; and the initials E. R., crowned, on either side. The remaining spaces are filled in with roses, arabesques and other devices; a few of which are in outline and coloured black. The same collection contains, also, two simple bindings executed for the same prince : the one, La Geografia di Claudio Ptolemeo, Venice, $\mathrm{I} 548$ [C. 20. a. I.], is tooled with the legend omnis POTESTAS A DEO, and a single border line, in gold; while the edges of the leaves are painted with the arms and initials of the king, in gold and colours : the other, De Amplitudine Misericordiae Dei, by Marsilo Andreasi, Basle, I550 [C. 46. c. 3r.], bears on each cover, the arms and initials of the king, within a blind fillet, with gilt fleurons at the angles.

Thomas Berthelet was still living in the reign of Philip and Mary. He died, according to an entry in the Register of the Stationers' Company, about January, 1556 ; and there are bindings executed for Queen Mary, which have all the characteristics of the earlier bindings attributed to this stationer. Of these, the most important is a copy of Bonner's Profitable and necessarye Doctrine, London, I555, 


\section{English Bindings}

from the Old Royal Library; upon the boards of which the arms of England are tooled within a flamed circle; while the enriched fillet forming the panel, is of a Venetian pattern, which in several instances occurs upon these bindings [C. 27. e. 13.]. Another and simpler example covers the manuscript of a controversial poem, against the Reformers, addressed by the author, Myles Huggard, to the queen. The arms of England again occur within a flamed circle; with the initials M.R. repeated at the points of a square, about the same: while a single border-line in gold, with fleurons at the angles, complete the decoration of this binding [Harl. mS. 3444.]. A third binding, executed for Queen Mary, covers a book of Hours in illuminated manuscript; the gilding of which is executed with finer tools, and is worked with greater care, than is usual upon these bindings by Berthelet; while the enriched borderfillet, which surrounds the arms and initial of the queen on each cover, is less Italianate in character [Sloane MS. 2565.].

These gold-tooled bindings, which, in the absence of any precise information as to the gilder, or gilders, who finished them, have come to be attributed to Thomas Berthelet, possess certain characteristics in common. Unlike the Elizabethan bindings, which followed them, they are imitated wholly from the work of Italian gilders; the tools being solid, and generally cut after Venetian patterns. When the device of the interlaced fillet is employed, it occurs 


\section{72 Bookbinding}

with very little elaboration; the simple form of the oblong interlaced with the lozenge, being ordinarily used : while the flamed circle commonly occurs as a centre piece on the covers; and blind lines usually accompany the gilt work of the border-fillets. With one exception, the examples, which I have described, are bound in brown leather, which is probably either calf, or deer-skin : and their gilding is more heavily worked, than that of the fine Italian bindings, contemporaneous with them. In common with a great number of English bindings, their historical interest exceeds their artistic value : but they are superior, for the most part, to the gold-tooled bindings, which followed them; for they were imitated from better models.

Another example of the influence of Venetian design on English bookbinding at this time, may be seen on a little volume, Basilii Magni et Gregorii Nazianzeni Epistolae Graecae, Hagenau, I528, bound for William Cecil, afterwards Lord Treasurer Burghley, and stamped with his name and that of his second wife, thus, WILLIAM-MYLDRED-CICYLL, within an enriched border-fillet [C. 65. e. I9.] : and yet another on a book in the Grenville Library, Tractatio de Sacramentis, by Joannes a Lasco, London, $\mathrm{I}_{552}$ [G. II 698 .].

The Italianate character, which English bookbinding assumed in the sixteenth century, is to be in some measure attributed to the considerable importation of foreign books, during the early part of the 


\section{English Bindings}

reign of Henry viII. This importation so greatly increased to the detriment of English printers and binders, that in 1533 the following Act was passed for the protection of their interests. "Where as by the prouision of a statute made in the fyrste yere of the reygne of kynge Rycharde the thyrde, it was prouided in the same acte, that all straungers repayrynge in to this realme, myghte laufully bringe in to the sayd realme printed and writen bokes to selle at theyr libertie and pleasure. By force of whiche prouision there hath comen in to this realme sithen the makynge of the same, a marueylous nombre of printed bookes and daylye dothe. And the cause of the makynge of the same prouysion semethe to be, for that there were but fewe bokes and fewe printers with in this realme atte that tyme, whyche coulde welle exercise and occupie the sayd science and crafte of pryntynge: Never the lesse, sythen the makynge of the sayde prouisyon, manye of this realme, beynge the kynges naturalle subiectes, haue gyuen them soo delygentelye to lerne and exercyse the sayde crafte of printynge, that at this daye there be within this realme a greate nombre counnynge and experte in the sayde science or crafte of pryntynge, as able to exercyse the sayde crafte in all poyntes, as anye straunger in anye other realme or contray. And further more where there be a greate numbre of the kynges subiectes within this realme, whiche lyue by the crafte and mysterye of byndynge of books, and that there be a greate multitude welle experte in the 


\section{I74 Bookbinding}

same: yet all this not withstandynge there are dyuers persons, that bringe from beyonde the se greate plentie of printed bookes, not onelye in the latyne tonge, but also in our maternall englishe tonge, some bounde in bordes, some in lether, and some in parchement, and them selle by retayle, wherby many of the kynges subiectes, beinge bynders of bokes, \& hauing none other facultie wherwith to gette theyr lyuinge, be destitute of worke, and lyke to be vndone: except some reformation herin be had. Be it therefore enacted by the kynge oure soverayne lorde, the lordes spiritual and temporal, and the commons in this present parlyament assembled, and by auctoritic of the same, that the sayde Prouiso, made the fyrst yere of the sayd King Richarde the thirde, from the feaste of the natiuitie of our lorde god nexte commynge, shalbe voyde and of none effecte.

'And further be it enacted by the auctorite afore sayde, that no person or persons, resiant or inhabitant within this realme, after the sayd feast of Christmas next comyng, shal bie to sel ageyne any printed bokes brought from any parties out of the kynges obeysance, redye bounden in bordes, lether, or parchement, uppon peyne to lose and forfayte for everye boke bounde oute of the sayde kynges obeysance, and brought into this realme, and bought by any person or persons within the same to sell agayne, contrarie to this act, syxe shyllynge eyghte pence.

'And be it further enacted by the auctorite afore- 


\section{English Bindings}

sayde, that no persone or persones inhabytant or resiante within this realme, after the saide feaste of Christmas, shall bye within this realme, of any stranger, borne oute of the kynges obedience other then of denizens, any maner of printed bokes, brought from any the parties beyond the see, except onely by engrose \& not by retayle : upon peine of forfaiture of vi.s. viii.d. for every boke so bought by retayle, contrarie to the fourme \& effect of this estatute, the said forfaytures, to be always leuied of the byers of any suche bookes, contrarie to this act:' etc. Provided alwaye,' etc.

[Anno xxv. Henrici virl. Actis made in the session of this present parliment, cap. xv. London,

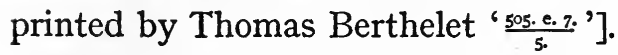

This Act appears to have afforded somewhat less protection to the bookbinders than they probably expected; for although it restricted the importation of bound books into this country, it does not appear to have affected the settlement of foreign bookbinders in London, who, no doubt, on account of their superior skill, succeeded to a considerable extent, in drawing to themselves the trade of the English workmen. The same thing happened with printers. Reyner Wolfe, Thomas Geminus, Stephen Mierdman, Vautrollier and others were foreigners. Among the minutes of the Stationers' Company, printed by Mr. Arber in his transcript of their Register, are several orders directed against this abuse, which continued throughout the century. 


\section{76 Bookbinding}

At a court held on 2Ist October, 1577 , it was resolved, among other things, 'that the bookebinders that be Inglishemen and fremen of this citie shall have woorke before strangers and foryners,' so that they do their work in a workmanlike manner, and at a reasonable rate [Vol. ii. p. 880.]. In I586, this grievance of the English binders was represented to the Lord Mayor and the Court of Aldermen, when an 'Acte of Common Councell made for restraynte of setting forreyners on work the firste daie of Auguste in the third and fourth yeres of kinge Philipp and Queen Mary,' was again put in force : and in a second petition 'againste ye nombers of fforreyners and Straungers, then intrudded into the trade and workes' of the bookbinders, presented to the same authorities, on 6th October, I597, we read that 'the nomber of forreyners are more encreased ' since the time of the former address, "through their dailie repaire from all partes of the realme to London'; and that the number of bookbinders, 'freemen, taxable to their Companies and to the Cittie,' was no greater than forty-six. They, therefore, pray to 'haue the Statute in force for forreyners As other Companyes haue and do execute Or ellse your poore Suppliantes shal be in case to be vtterly ruynat and vndone' [Vol. ii. p. 8oo, etc., and vol. iii. p. 40.]. This second petition would seem to have gained for them some substantial relief, as their grievance does not again appear to have been brought before the court of the Stationers' Company. 


\section{English Bindings}

It is to this settlement of foreign binders in London, that the occurrence of such distinguished designs as those executed on the books of Thomas Wotton, is to be attributed ; if not, indeed, those general characteristics of Elizabethan bindings, which show the undoubted influence of Lyonese art upon English workmanship.

In the absence of any evidence, as to what stationers furnished the Royal Library with bindings, during the reign of Elizabeth; it may, not without some reason, be surmised, that the Queen's Printer continued to purvey them, as Thomas Berthelet had done in the previous reigns. At the accession of Mary, Richard Grafton having printed a proclamation declaring Lady Jane Grey, queen, hardly escaped with his life; and the office of Queen's Printer was granted by patent to John Cawood, on the 29th December, I553, who continued to hold the office under Elizabeth, conjointly with Richard Jugge. Cawood, however, dying in I572, Jugge enjoyed the privileges of that office, alone, until his death in 1577 ; when the monopolies of the place were sold to Christopher Barker, 'for a greate somme of money,' by Master Wilkes, to whom they had been granted, doubtless, for this purpose. Christopher Barker was, in turn, succeeded by his son Robert.

There are but few gold-tooled bindings, executed for Elizabeth, which remain among the books of the Old Royal Collection. A copy of Edward Grant's 


\section{78 \\ Bookbinding}

Graecae Linguae Spicilegium, London, 1575, is covered in brown leather, and tooled in gold with the queen's arms in the centre, and azured cornerstamps at the angles, of the boards; while their field is powdered with small roses [C. 24. a. 22.]. Among the manuscripts in the British Museum, is a volume of Latin pieces presented to Elizabeth in I563, upon the occasion of a visit to Eton College, Etonensis Scholae Ovatio de adventu R. Elizabetae ad arces Vindesorenses. It is bound in vellum, and elaborately decorated in gold, with the royal arms, the initials of the queen, and heavy corner-stamps, surrounded by an enriched border-fillet, which is imitated from a common Venetian pattern, but azured. The gilding upon this book, which is very roughly executed, is the work in all probability of some local binder [Royal Ms., I2, A, xxx.]. Of a more English character, are the bindings of two books in the same collection, which, in so far as their difference in size would allow, are tooled in a similar manner. The smaller volume is the copy, presented to the queen by John Fox, who edited the edition, of the Gospels in Anglo-Saxon and English, printed by John Day at London, in I57I, at the instance of Archbishop Parker [675. f.]. The larger volume is a copy of Matthew of Westminster, presented to the queen by the same prelate; Flores Historiarum per Matthaeum Westmonasteriensem collecti, London, I570, printed by Thomas Marsh [C. I8. b. II.]. These volumes are covered in brown 


\section{English Bindings}

leather, and tooled in gold, on either cover, with the arms and initials of the queen in the centre, and with azured corner-pieces at the angles, of the panel; the field being powdered with triple dots: while the further addition of a centre piece, with angle, and on the larger volume, side, pieces, stamped in gold upon white leather inlaid, completes the design. Among the ornaments of these side, and angle, pieces, which consist of arms and other martial devices, is a label, bearing the initials I. D. P., which, as they occur on the smaller volume printed by John Day, may stand for 'John Day, printer,' or, perhaps, for 'Johannes Day pegit.' This celebrated man was much assisted by Matthew Parker, and was employed by him to print his work, De Antiquitate Britannicae Ecclesiae: the archbishop would, therefore, not unnaturally, employ the same stationer to bind the copy of Matthew of Westminster, which he intended for presentation to the queen. John Day, having followed the business of a printer for about forty years, died in 1584 . Unlike the gilding upon the books of Thomas Berthelet, which was imitated for the most part from Venetian work, these Elizabethan bindings, especially in the use of stamps and azured cornerpieces, show the very different influence of the Lyonese school of binders, which was at its height about this time: and the more these bindings depart from the character of their originals, and reveal some trait, or other, which is peculiarly English, as 


\section{I $80 \quad$ Bookbinding}

in the case of the two bindings by John Day, the less satisfactory do they become in regard to their design.

The simpler b:ndings of Elizabeth often bear the badge of the crowned falcon, holding a sceptre, which had been the device of her mother, Anne Boleyn; as on a copy of Justinus' Trogi Pompeii Historiarum Philippicarum epitoma, Paris, I58I [C. 27. g. 7.]. But Elizabeth appears chiefly to have affected embroidered and velvet bindings, if we may judge from the remains of her library, and from the account of the books, which Paul Hentzner, a native of Brandenburg, saw at Whitehall, when

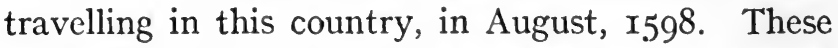
books, he tells us, in his Itincrarium, were all bound in velvet of different colours, although chiefly red, with clasps of gold and silver; some having pearls and precious stones set in their bindings. I may mention, as examples of these, a small book, Orationis Dominicae Explicatio, by Lambert Daneau, Geneva, 1583 , covered in black velvet, and embroidered with roses, in gold and silver thread, which is preserved in the Old Royal Library, and which was apparently worked for Elizabeth [C. 24. a. 34.]; and a little volume of devotions, Meditationum ac precationum Christianarum libellus, Lyons, I570, bound in red velvet, and embellished with gold clasps, centre, and angle, pieces, which are enamelled in colours, with a crowned rose, the initials E. R., and other ornaments [Show Case xxvir. I3.]. In 


\section{English Bindings}

such examples as these, we have Elizabethan bookbinding at its perfection : indeed, this little volume, with its enamelled work, might, in its kind, be placed beside the miniatures of Peter Oliver, or some contemporary jeweller's work, for beauty and exquisite workmanship.

During the sixteenth century, the private libraries in England, which contained any considerable number of books, were few ; and these were chiefly formed during the reign of Elizabeth. Of the bindings executed for the owners of these libraries, the most remarkable are those made for Thomas Wotton, the father of that incomparable writer, Sir Henry Wotton. This collector not only adapted to his use the legend of Grolier; the inscription, THOMAE WOTTONI ET AMICORVM, being commonly tooled on his books, although his arms sometimes occur alone; but the designs upon his books, which, from their distinguished and uniform character, would appear to have been the work of the same gilder, were conceived in the manner, which is associated with the books of the French Treasurer. From these circumstances, Thomas Wotton has come to be known as the English Grolier : but the comparison will not bear too close a scrutiny; for the gilding upon his books is neither designed with the same purity of taste, nor worked with the same accomplishment, as that upon the bindings executed for Grolier; yet, even at this estimate, they are the finest which were produced in England, during the 


\section{r 82 Bookbinding}

reign of Elizabeth. These books of Thomas Wotton are commonly bound in brown leather, decorated with a fillet, elaborately interlaced, and painted, and finished with arabesque gold-tooling, which is sometimes azured, and sometimes worked in outline, and painted: occasionally there is a further addition of some medallions, or busts. A copy of a translation into French, by Estienne Dolet, of the Quaestiones Tusculanae of Cicero, Lyons, 1543, in the Museum, is bound in this manner with a painted fillet and gold-tooling [C. 19. b. 30.]. The legend, THOMAE WOTTONI ET AMICORVM, is tooled across the central compartment of the covers: while upon another volume in the same collection, a copy of Pliny's Historia Mundi, Lyons, 1548, his arms take the place of the inscription [C. I9. g. 2.]. Among the illustrations to the Catalogue of Bindings, exhibited at the Burlington Fine Arts Club, is figured a third example, equally fine with the two in the British Museum : it is tooled in blind, with a fillet and busts stained in black [Case L, No. 23.]. This collector died in 1587 .

Earlier in the century, Henry Fitzalan, Earl of Arundel, had commenced the formation of his library, when the recent suppression of the monasteries enabled him to readily obtain many books of value; and at the death of Cranmer, he acquired a considerable portion of the Archbishop's library. His collection was bequeathed by him to his son-in-law, Lord Lumley, tutor to Henry, Prince of Wales, by whom 


\section{English Bindings}

they were purchased upon the death of their owner, in I609. It is to be regretted, that Henry caused this splendid library to be rebound, and tooled with his own arms and devices : a few volumes, however, escaped; and among the books of the Old Royal Library, is a copy of the Vulgate, printed at Venice in I544, and retaining a contemporary binding, apparently of foreign workmanship, which bears the device of the white horse, the badge of the Earl of Arundel, upon either cover [C. 27. f. 5.].

Of the library of Robert Dudley, Earl of Leicester, little is known; but many fine bindings, stamped with his arms, or his crest of the bear and ragged staff, are still in existence. Two books in the British Museum; the one, the Symposium of Plato, Paris, I543 [C. r9. c. 23.]; the other, the Works of Clemens Alexandrinus, also in Greek, Florence, I550 [G. Ir,780.]; bear this crest in an oval, in the centre of either board, in one case accompanied with his initials R. D., and with azured corner-stamps at the angles of the panels ; while the remaining portions of the field are elegantly tooled in gold, in the Lyonese manner. I have already described a book, bound for Lord Burghley, and tooled with his name, and that of his second wife: but his bindings are more generally stamped with his arms. Lord Howard of Effingham and Archbishop Whitgift, amongst others, had books bound for them with their arms: and Archbishop Parker especially took an interest in bookbinding. Writing to Lord Burghley, on the gth 
of May, I573, at the time he was issuing his famous work, De Antiquitate Britannicae Ecclesiae, the first book privately printed in England, he says that he had then, 'within his house on wages, drawers and cutters, painters, limners, writers and bookbinders '; and adds, that he has sent Lord Burghley a copy of it 'bound by my man.' The copy of this work, which the Archbishop presented to the queen, is still preserved among the books of the Old Royal Library: it is bound in green velvet, elaborately embro:dered, in gold and silver thread and coloured silks, with the representation of a paled deer-park containing deer, with a rose-bush, snakes and various flowers [C. 24. b. 7.].

At the time of the accession of James to the throne of England, the name of a master-binder, who appears to have followed his trade apart from that of a printer, or stationer, first occurs in the annals of English gold-tooled binding. Already, while James was in Scotland, John Gibson had been appointed the King's Binder, in 1580 ; and a bill for books bound by him has been printed by Dibdin, in his Decameron. Upon the arrival of James in London, the office of the Bookbinder to the King was granted for life, by a warrant, dated 3rd May, I604, to John and Abraham Bateman, at a yearly fee of $6 l$. : and on the I8th January, I6I2, a warrant dormant was issued for the delivery of stuff, yearly, to John Bateman for his livery. Both Robert Barker, the King's Printer in Ordinary, and John Norton, the King's 


\section{English Bindings}

Printer for the Latin, Greek and Hebrew tongues, also, supplied bindings for the royal service: and docquets, or entries, of several warrants remain, directing certain payments to be made to them, on that account. Thus, upon the I3th November, I6o9, a warrant was issued for the payment of $173 l$. $16 s .4 d$. to John Norton, for binding sundry books covered with velvet : and again on the 20th December, 1609, and on the 6th August, I6II, other warrants were issued for two several payments to Robert Barker, for printing and binding sundry books [Vide Calendar of State Papers, Dom. Jac. I., under their respective dates.]. No detailed bills of account, rendered by these binders and printers, if, indeed, any remain in the Record Office, have yet been discovered; nor has any example of their work hitherto been identified. It is, however, probable, that Robert Barker, and John Norton, furnished only the bindings of the books, which they themselves printed: while other bindings, executed at this time for the Royal Library, were the work of John and Abraham Bateman.

A considerable number of gold-tooled bindings, executed for James I., remain among the books of the Old Royal Library, in the British Museum; and these, for the most part, in the manner of their design, are founded upon the gold-tooled bindings of the previous reign. On some examples, the boards are stamped with the arms of England in the centre, and with heavy azured corner-stamps at the angles; 


\section{86}

\section{Bookbinding}

while their field is powdered with a device : as on a copy of Isaac Casaubon's De rebus sacris et ecclesiasticis exercitationes, London, I6I4 [C. 24. c. 3.]. Although such a design, in its essential elements, already occurs upon Elizabethan bindings, the manner of treating it is new, and more English in character. The form of the central stamp is no longer imitated from some Lyonese original; the diaper of the field is heavier, and the corner-stamps, less obtrusive, in their appearance: unlike the gold-tooled bindings of the age of Elizabeth, they are conceived in a spirit, which is unmistakably English. On other examples the corner-stamps are no longer azured; but designed in a manner which accords with that of the central coat : as on a copy of Archbishop Bradwardine's treatise De causa Dei, contra Pelagium, London, I6r8 [C. 24. d. I6.]. More commonly, perhaps, the corner-stamps are dispensed with altogether: and the royal arms, with a diaper of some device, form the chief ornaments of the boards. Thus fleurs-de-lis and flaming hearts are powdered upon a copy of Laurent Bouchel's La Bibliothèque, ou Thresor du Droict François, Paris, I6I5 [C. 24. d. I4.]; the Scottish thistle on a copy of Bishop Godwin's Rerum Anglicarum, Henrico VIII., Edwardo VI., et Maria, regnantibus, Annales, London, I6I6 [C. 47. k.]; and the thistles, fleurs-de-lis, and what may be intended for roses on a Pontificale Romanum, Rome, I595 [C. 24. d. I0.]. Although these bindings are greatly inferior to the fine contemporaneous 


\section{English Bindings}

bindings of France, in the execution and elegancy of their gilding; yet they are always pleasing on account of the original treatment, and the effective sense of decoration, which distinguish their design.

Far less satisfactory, for the most part, are the bindings executed for Henry, Prince of Wales. I have already related how Lord Lumley's books were acquired, and rebound, by him; a process in which many early bindings of great value, must have been destroyed. The books of this Prince are commonly covered in calf, with his arms stamped in the centre, and various devices at the angles, of the boards. Thus on a copy of Jean Bouchet's Les Annalles Dacquitaine, Paris, I540 [596. h. I4], crowned roses occur at the corners : while on other books in the Old Royal Library, fleurs-de-lis, crowned lions, or the Prince of Wales' badge, are found. The stamps on these examples are coarsely and heavily designed, without relation to one another, or to the books, which they ornament ; but they are the least pleasing of the bindings executed for Prince Henry. Others, though somewhat heavily gilded, show more invention in their design, as that of a copy of Livy, Geneva, I609 [C. 48. k. I.]: while a few, tooled with greater elegancy, are decorated with laurel branches, which are evidently imitated from the styles of the Eves; as on a copy of David Rivault's Les Elemens de l'Artillerie, Paris, I608 [C. 46. b.].

In the reign of Charles I., English gilding distinctly 


\section{88 Bookbinding}

reveals the influence of the Parisian binders: a greater number of tools are employed; and these are both smaller, and more finely engraved, than those which occur upon the bindings of James $\mathrm{I}$. But neither is the design of these tools, nor the manner in which they are used and combined, comparable to the achievement of the French gilders. An admirable example of the kind may be seen on a copy of the Oxford Statutes, presented by the University to Charles I., Corpus Statutorum Universitatis Oxoniensis, Oxford, I634 [C. 24. d. II.]. It is covered in dark blue morocco, and is very elaborately tooled, with the royal arms in the centre of each board. Another, and smaller, volume, also in the British Museum, being various treatises presented to the king, is tooled in the same manner, with his arms, initials, and the legend, TIBI SOLI O REX CHARISSIME, and furnished with engraved silver clasps [Eg. Ms. II40.]. A third example of singular interest, also, in the British Museum [Show Case virr. 4.], consists of a box, shaped like a folio volume, and covered in olive-green morocco, which contains the travelling library of Sir Julius Caesar, Master of the Rolls in the reign of James $\mathrm{I}$. The tooling on the outside of the case is fine and elaborate: and the inside of the lid is painted with a list of the books, which are fortyfour in number, with the arms of Sir Julius and two of his three wives, and with other decorations. The books themselves are bound in vellum, variously tooled in gold, and furnished with differently 


\section{English Bindings}

coloured ribbons, according as they contain theological, philosophical, historical, or poetical, works. They bear dates ranging from I590, to I620; so that this interesting collection was probably made for Sir Julius Caesar soon after the latter year.

Among the styles in vogue with the stationers, during the reign of Charles I., was one especially characteristic, in which the whole surface of both boards was covered by a diaper of small lozenges, or circles, embellished by figured tools, and sometimes alternately azured. Such designs are generally heavily gilded, and are peculiarly English. Two examples of this kind may be found figured in the Catalogue of the Burlington Fine Arts Club [Case M. 35, and 37.].

During this reign were, also, executed the bindings of the famous Harmonies, compiled by Nicholas Ferrar, after his retirement to Little Gidding, in Huntingdonshire; where he and his family formed themselves into a kind of religious community. These bindings must be considered apart from the productions of the stationers and professed bookbinders, as the first and most remarkable examples of gold-tooling executed, in this country, by amateurs. Of Nicholas Ferrar and his family, it is not necessary here to speak : for their history has attracted more than common attention, during recent years ; especially on account of Mr. Shorthouse's romance, John Inglesant, in which a picture of their community, and the figure of Mary Collet, conspicuously occur. 


\section{r9o Bookbinding}

I shall, therefore, speak only of the bindings executed by them. 'Amongst other articles of instruction and amusement,' Dr. Peckard tells us, 'Mr. Ferrar entertained an ingenious bookbinder who taught the family, females as well as males, the whole art and skill of bookbinding, gilding, lettering, and what they called pasting-printing, by the use of the rolling-press.' It appears, from John Ferrar's life of his brother, that the person, who taught the family, was a daughter of a Cambridge binder,-perhaps, the craftsman who worked for Thomas and John Buck; according to a conjecture put forward in an article, which appeared in Bibliographica, Vol. II., on 'Little Gidding Bindings,' by Cyril Davenport. 'By this assistance,' continues Peckard, 'he composed a full Harmony, or Concordance of the four Evangelists, adorned with many beautiful pictures, which required more than a year for the composition, and was divided into $5_{50}$ heads or chapters. For this purpose he set apart a handsome room near the oratory.' Elsewhere, John Ferrar gives a description of this 'long fair spacious room,' which, he says, 'they named the concordance chamber, wherein were large tables round the sides of the walls, placed for their better conveniency and contrivement of their works of this and the like kind; and therein also were placed two very large and great presses, which were turned with iron bars, for the effecting of their designs.' This room was 'all coloured over with green pleasant colour varnished, 


\section{English Bindings}

for the more pleasure to their eyes, and a chimney in it for more warmth, as occasion served': while upon the walls were written various legends, as 'Thou art too delicate, $\mathrm{O}$ brother, if thou desirest to reign both here with the world, and hereafter to reign with Christ in heaven,' and other such sentences. Here, according to the former narrative, John Ferrar, having provided two copies of the Gospels of the same edition, 'spent more than an hour every day in the contrivance of this book, and in directing his nieces, who attended him for that purpose, how they should cut out such and such particular passages out of the two printed copies of any part of each Evangelist, and then lay them together so as to perfect such a head or chapter as he designed. This they did first roughly, and then with nice knives, and scissàrs so neatly fitted each passage to the next belonging to it, and afterwards pasted them so even and smoothly together, upon large sheets of the best white paper, by the help of the rolling-press, that many curious persons who saw the work when it was done, were deceived, and thought that it had been printed in the ordinary way.' The fame of this book, which had been compiled only for the religious uses of the community, 'somewhat of it' being repeated every hour by them, reached the ears of King Charles, who, happening in his progress to be at Apthorpe, at the Earl of Westmoreland's house, about seven miles from Gidding, sent for this volume by a gentleman of his 
court. After some ado, Nicholas Ferrar being then at London, the book was given to the gentleman of the king, upon his engaging his faith, that at the king's departure from Apthorpe, he would bring it again : ' but,' continues John Ferrar, 'a quarter of a year past. Then came the gentleman again, but brought no book; but after much complement said, the king so liked the work itself, and the contrivement of it in all kinds, that there had not a day passed, but the king, in the midst of all his progress and sports, spent one hour in the perusing of it: and that would apparently be seen by the notations, which he had made upon the margins of it with his own hand: and that his master would upon no terms part with it, except he brought him a promise from the family, that they would make him one for his daily use, which he should esteem as a rich jewel.' ' Before the year came about, such diligence and expedition was used, that a book was presented to his majesty, being bound in crimson velvet and richly gilded upon the velvet, a thing not usual.' This volume still remains among the books of the Old Royal Co!lection, in the British Museum : it is a Harmony of the Four Gospels, and it is dated 1635 [C. 23. e. 4.]. It probably had a loose covering of velvet, which is now lost, and which would account for John Ferrar's description of its binding. According to Dr. Peckard, this book 'was bound entirely by Mary Collet (one of Mr. Ferrar's nieces) all wrought in gold in a new and most elegant fashion.' 


\section{English Bindings}

The book is covered in black morocco, and the design of the gilding is, certainly, original, being unlike any style in use, at that time. It is composed of a number of fine, small tools, which are arranged so as to form a lozenge within a panel, in the centre of which is a circle, with quarter-circles at the angles. The letters I.H.S. occur within the circle: and among the small tools, which are imitated, for the most part, from those in use by contemporary French binders, but seem in many cases to have been obtained from T. \& J. Buck of Cambridge, is that of a small heart, which is repeated a great number of times. These tools, however, are not massed with a proper knowledge of decorative effect: and the appearance of the boards is somewhat meagre, and unsatisfactory, when set beside the work of accomplished gilders. Yet the book is, perhaps, not to be judged in this way; but to be regarded chiefly for its historic interest, which is beyond dispute. The original Harmony, containing the marginalia of the king, which had been returned to Nicholas Ferrar, perished in all probability, when the church and house at Little Gidding were sacked, not long before the beheadal of Charles.

A Harmony of the Books of Kings and Chronicles was next undertaken, at the express desire of the king for his own use; and like the former Harmony, remains among the books of the Old Royal Collection [Royal Ms. app. I5.]. It is dated I637; and is bound 


\section{I94 Bookbinding}

in black morocco, tooled in gold with a series of single lines, returned at equal distances so as to cover the whole field of the boards, except a small central panel, which is decorated with a flowered centre-piece; while other figured tools are impressed at the inner angles, formed by these lines. The back is without bands, similarly ornamented, and is stamped with the initials C. R. at the tail. Although the design of this binding is of a very simple nature, it is both effective and original. The British Museum contains, also, the Books of the Acts of the Apostles and the Revelations of Saint John, illustrated with various engravings, 'elegantiss. monochromatis delineata,' runs the phrase on the title-page. The book is without date, nor is anything known of its history. It is covered in brown morocco; and the whole field of either board, except for a figured border, tooled with a diaper of lozenges alternately azured, or ornamented with a small device, in gold, while the back is enriched with bands, and is similarly decorated [C. 23. e. 3.]. The gilding on this binding is more heavily handled, than that on the Harmony of the Gospels, executed for the king; and has, indeed, much in common with the stationers' bindings of the time.

Prince Charles having expressed his desire to possess a Harmony, like that done for the king, Nicholas Ferrar being dead, his young nephew who bore his name, and had attained to the knowledge of several languages, prepared one in English, Latin, 


\section{English Bindings}

French and Italian. On the outside, it was 'all green velvet stately and richly gilt all over, with great broad strings, edged with gold lace, and curiously bound.' This book is now in the library at Somerley, belonging to the Earl of Normanton : it is dated I640, and the green velvet of the binding is tooled in gold with sprigs of oak and fleur-de-lis. Among the various books described by Mr. Acland-Troyte, in a paper, which he contributed to the Archaeologia, is a Pentateuch which belonged to Captain Gaussen, bound in purple velvet, and tooled with small crowns in gold. This is apparently the book made for Prince Charles about the year I642. Another Pentateuch, also covered with purple velvet gilt, remains among the books given by Laud to St. John's College, at Oxford: and yet another binding of this kind is in the possession of the Marquis of Salisbury, at Hatfield. Besides these books, the same writer, also, describes four other Harmonies of the Gospels, in private possession; three of which are bound in leather, while the fourth is bound in an unusual manner. This book was formerly the property of Mary Collet, from whose family it descended to Mr. Harold Mapletoft Davis, of New South Wales, and from him passed to the British Museum. It is bound in parchment, stained red, and decorated with centre and angle pieces of white parchment, pierced and gilded. A number of embroidered bindings have been ascribed to the members of Nicholas Ferrar's family at Little Gidding: but there does 


\section{r 96 Bookbinding}

not appear to be any ground for attributing such work to them. [P. Peckard, 'Memoirs of the Life of Mr. Nicholas Ferrar,' Cambridge, I790. J. E. B. Mayor, 'Cambridge in the Seventeenth Century;' Part I. 'Nicholas Ferrar;' two lives by his brother John, and by Dr Jebb, Cambridge, I855. J. E. Acland-Troyte, 'An Account of the Harmonies contrived by Nicholas Ferrar,' in two papers, contributed to Vol. LI. of the Archacologia, London, I888.].

During the Civil Wars, the progress of Bookbinding, as of every other fine art, was interrupted ; and at the close of the Interregnum, its character had become changed. I read in the Record Office, that Charles I. being at Oxford in I644, Francis Bowman, 'was sworne his Mats seruant to attend his Royall sonnes the Prince and Duke of Yorke in the quallity of Stationer Bookeseller and Bookebinder.' In the month of May, I660, on the eve of the Restoration, this stationer 'deliverd to his Maties owne hand when he was in Holland at ye Hague, 2 of his owne pictures richly done in sattin \& fringe,' and ' 3 more ordinaryly done'; embroideries, apparently, executed by the persons, who worked the covers of books. After Charles II.'s return to England, he petitioned the king to have his place of stationer, which, he states, 'one Henry Seile hath lately by surprize (vpon some vntrue pretences) got himself sworne into,' restored to him : and he appears to have succeeded in his request, 


\section{English Bindings}

for a bill of his exists for bound books and stationery, supplied to the king's use, between the years I66o and 1663 [S. P., Dom. Car. II., vol. ii., 75, 75 ${ }^{1}$; and vol. lxxxiv. I06.]. I have not, as yet, been able to trace any of the books described in Francis Bowman's bill.

At the Restoration, the office of Bookbinder to the king was granted, in June I66o, to Samuel Mearne, 'dureing his life, with ye yearely ffee of 6li ' [Car. II., Docquet Book, I66o-I, p. 4.]: at this time, Mearne was living in Little Britain. Among the accounts of the Great Wardrobe, I find an almost unbroken series of entries relating to him, between the years 1663 and I683; after which date occurs the name of Charles Mearne, who was probably his son. These entries are chiefly of Bibles and Prayer-Books, bound by him for the use of the royal chapels : though they contain, also, references to books which he bound for the Royal Library at St. James, and which are collectively described; as for example: 'pro colligendis $\mathrm{IV}^{\mathrm{c}}$ libris rubro corrio Turci pro Bibliotheca apud domum Sancti Jacobi.' A considerable number of books, bound thus for Charles Ir., remains in the Old Royal Collection; one of which, Historia de Los Reyes Godos, by Julian del Castillo, Burgos, I582 [594, g. 2.], may be selected for description. This book is covered in red morocco of the very finest kind, the joints being still fresh and unbroken : and on the boards and back are to be found all the principal 


\section{98}

\section{Bookbinding}

tools occurring upon these bindings, which are without doubt the work of Samuel Mearne. The figured work on the panels of the back is worked by a pallet: and the two Cs interlaced and crowned, between branches of palm, which also occur on this back, take the place of the 'fleurons' at the angles of the panels of the boards, upon other examples; as on a copy of Paolo Paruta's Historia Venetiana, Venice, I605 [592. e. 9 \& Io.].

The British Muscum, also, possesses a Book of Common Prayer, London, I669, in an exceedingly rich binding, bearing the crowned cypher of Charles II., which is, apparently, also the work of Samuel Mearne [468. b. 13.]. It is covered in purple morocco; and the fillets of the panels and centre-pieces are inlaid with black leather. The elaborate filigree gilding, which covers the boards, shows the influence of French work upon its designer; and many of the tools are engraved with a broken line, consisting not of a series of dots or points, as in the tools of Le Gascon, but of tiny oblongs. Notwithstanding these traits of design, the character of this binding remains distinctively English; partly on account of the forms and arrangements of its various ornaments ; and partly on account of its general design, which is an early example of what is known as the cottage style, so called from the head and tail of the panels on the boards resembling, in shape, the gable of a cottage. The sides of the panel are, also, generally broken 


\section{English Bindings}

into various curved forms. Although this style appears to have had its origin in France, during the first half of the seventeenth century, it became peculiarly associated with English work; and was especially used, for a time, upon the Bibles and Prayer-Books, printed at the University Presses of Oxford and Cambridge. To Samuel Mearne belongs the distinction, of having introduced into this country, and particularly upon his more simple bindings, an elegancy in the design and execution of his gilding, comparable, in no slight degree, with contemporaneous French work. In place of the more obviously decorative methods, which were in vogue before the time of the Restoration, he substituted a chastened and urbane manner, such as might become any gentleman's library; anticipating in some sort, as Dryden did in literature, the spirit of the succeeding century.

The bindings executed for private collectors, during the latter half of the seventeenth century, do not appear to have been either very numerous, or very remarkable. John Evelyn speaks, in a letter to Samuel Pepys, written in 1687 , of the scarcity of good libraries, at that time, in England; 'Paris alone, I am persuaded,' he adds, ' being able to show more than all the three nations of Great Britain.' The bindings executed for John Evelyn himself are, perhaps, the most remarkable: they are in the manner of Samuel Mearne; if, indeed, they be not his work. A facsimile of one of these, 


\section{0 \\ Bookbinding}

Primigeniae Voces linguae Graecae, Paris, I6I9, may be found among the Examples of Historic or Artistic Bookbinding, published by Mr. Quaritch [Pl. 82.]. The arms of John Evelyn, within an oval, are stamped in the centre, and his cypher, composed of the letters I. E., and surrounded by laurel branches at the angles of the boards: while the back is ornamented with his crest and cypher, in alternate panels: and there are books, bound in this way, remaining in the library at Wotton. About the time of the publication of Evelyn's diary, Mr. William Upcott, of the London Institution, who had been employed by Mr. Bray, the editor of the Diary, to copy the manuscript, was entrusted by Lady Evelyn with the duty of arranging the books and papers at Wotton. After the death of Lady Evelyn, Mr. Upcott continued his visits; and pictures, letters and books were abstracted by him: so that John Evelyn's library became partially scattered; while the sale-catalogues of Mr. Upcott's books and manuscripts, which were dispersed in I846, reveal the extent of these appropriations. The name of Notts has been mentioned, as binder to the great Earl of Clarendon; and that of Hugh Hutchinson to Bishop Cosin : but it would appear from Cosin's letters, that the latter workman was a bookseller of Newcastle, who was only employed by the Bishop to set the stamp of his arms on the backs of his books, after he had bestowed them upon the library at Durham. 


\section{English Bindings}

Very little has been collected about the history of English binding, from the reign of James II. to the time of Roger Payne. The mere names of the principal binders are but imperfectly known: and examples are rarely to be ascribed with any certainty, to a particular workman. William Churchhill and Edward Castle were the royal booksellers, bookbinders and stationers, from about I700 to I755 : and in the British Museum are many royal bindings, of that period, some of which may have been executed by them. The styles, which were introduced into England at the time of the Restoration, especially the cottage style, continued to be used on these books; but with successive changes of manner. The earlier examples are the more admirable. A little volume covered in red morocco, Recueil de diverses pièces servans a l'histoire de Henri III., Roy de France, I662, bears the crowned cypher of William III. neatly interwoven, for its single ornament [C. 47. a. 24.]. Among the cottage bindings is a copy of an Anglo-Saxon Homily on the Birth-day of St. Gregory, written by Aelfric, Archbishop of Canterbury, and translated by Elizabeth Elstob, London, I709, the binding of which is tooled with the crowned cypher of Queen Anne, and though carefully designed, is somewhat hard and mechanical in appearance [223. i. 4.]. From this time, English gilding rapidly degenerated : the cottage binding of a manuscript, $A n$ account of what passed in a conference concerning the Succession to 
the Crown, bearing the arms and cypher of George I. [Stowe MS. 249.], and more especially that of a copy of William Musgrave's Antiquitates Britanno-Belgicae precipuae Romanae, Exeter, I7I9 [142. a. 23.], tooled with the badge and initials of George, Prince of Wales, afterwards George II., illustrate in how short a time, that sense of a dignified style, and unity of composition, which distinguishes the cottage-bindings of Samuel Mearne, became lost to English gilders. At the beginning of the second half of the eighteenth century, the art of design had reached its lowest condition; and the deterioration of forwarding was no less complete. A volume bearing the arms and initials of George, Prince of Wales, afterwards George III., Der gantze Psalter, London, I75I, bound by Andreas Linde, bookbinder to the Prince, exhibits the coarse execution, and the crude ornamentation, unintentionally grotesque, which preceded the studied art of Roger Payne [2I8. d. 3.].

Much admirable work, however, both in workmanship and design, was executed for the stationers and private persons, by binders, whose names are now lost, at the end of the seventeenth, and in the first years of the eighteenth, centuries. During the former period, the fan style, which had its origin in Italy, no less than the cottage style, was much used by English binders. In both these styles, a great number of small tools, which were often of inferior design, and which introduced into the com- 


\section{English Bindings}

position an excessive number of elements, were combined with such skill, that the total effect was often very felicitous. Many pleasing imitations of Le Gascon's manner, and many inlaid bindings, were, also, produced about this time, examples of which may be found figured in the Catalogue of the Burlington Fine Arts Club [e.g. Case N, 38, 8, and 90.]: but far more admirable, and more native to English art, was a style of decoration, in vogue at the beginning of the eighteenth century; of which a copy of a theological work, preserved in the British Museum, A Paraphrase and Annotations upon all St. Paul's Epistles. Done by several Eminent men at Oxford, corrected and improv'd by the late Right Reverend and learned Bishop Fell, London, I702, is an admirable instance [C. 47. e. I8.]. It is covered in red morocco, inlaid with a black panel of the same leather; and elaborately tooled in gold, with branches of vine, and tulips, with other flowers and devices. In the design of this binding, which is admirably managed, and singularly pleasing in effect, English art, untouched by any foreign influence, is seen to its best advantage : how pleasing, and how various in design, were the English bindings of this time, may be seen from the illustrations to the Catalogue of the Burlington Fine Arts Club.

During the first quarter of the eighteenth century were executed the bindings of the Elegies and Congratulatory Poems, which Elkanah Settle, the City 


\section{Bookbinding}

Poet, and the butt of Dryden's wit, used to present to the numerous patrons of his muse. They are very coarsely, though somewhat effectively, executed; and from the similarity of the tools, which occur upon the various examples, they appear to have been the work of the same binder. One of several examples, preserved in the British Museum, A Funeral Poem to the Memory of the Right Honourable John, Earl of Dundonald, London, I720 [II63I. h. 20.], bears the following note in pencil upon the fly-leaf; 'Anne Cochrane my book sent me from London by Mr. E. Settle of the I6 of Novbr I720.'

But to pass to more accomplished work ; much of the fine binding, executed about this time, was done by Eliot and Chapman, who bound the celebrated library of Robert Harley, the first Earl of Oxford, at a cost, it is said, of $18,000 l$. They generally tooled their books with a rich centre-piece, commonly of a lozenge form, surrounded by a broad, tooled border ; a distinctive manner of ornamentation, which has since been known as the Harleian style. The leather used by them for the Earl's books was of a somewhat inferior quality; but for this they were not responsible, as it was supplied to them. They frequently complained of 'My Lord's leather,' and Mr. Chapman wanted to buy some of the skins at a cheap rate; but Mr. Wanley, Lord Oxford's librarian, told him that 'My Lord will not turn leather seller, and that he must agree to bind with my 


\section{English Bindings}

Lord's morocco skins, otherwise his Lordship will appoint some other binder to do so.'

Later in the century, Thomas Hollis, the republican, and the editor of Algernon Sidney's 'Discourses concerning Government,' and other works, employed Thomas Pingo, the medallist, to engrave a number of emblematic tools for him, more curious, than beautiful, with which he caused the bindings of his books to be decorated. He was in the habit of spending several hundred pounds a year on the production and purchase of books and medals, large numbers of which he gave to various libraries; those of Harvard, Berne and Zurich being especially favoured. It has been said, that he sought to adorn his bindings 'with tooling of a character appropriate to the work': but the accuracy of this statement would appear to be very doubtful. A copy of John Toland's Life of Milton, London, I76r, presented by Hollis to the British Museum, bears all the principal stamps, which occur on his bindings, with the exception of the cap of Liberty. On the upper cover of this book, the figure of Liberty, beneath a star, is stamped between a branch of palm and a branch of olive: on the lower cover, the figure of Britannia, also with a star, occurs between a cock and an owl; while the back is tooled with the Wand of Esculapius, and the Caduceus of Mercury [C. 66. e. 4.]. Thomas Hollis died in I774; and left his name and property to Thomas Brand, who continued to use these 
stamps : thus, the figures of Liberty and Britannia occur upon a copy of the Memoirs of Thomas Hollis, London, 1780 , which is also in the British Museum [6r3. 1. II.].

The art of bookbinding in England, which had reached the limit of its decadence, in regard both to design and workmanship, was now to be suddenly revived by the genius of Roger Payne. This extraordinary man was a native of Windsor Forest, and is thought to have been first employed by Pote, the bookseller of Eton. Coming to London, he was apprenticed to Thomas Osborne, a bookseller in Holborn; and was afterwards set up in business near Leicester Square, sometime between the years I766 and I770, by Thomas Payne, the principal bookseller of his time, who, though bearing no relation to him, showed him an unremitting benevolence, during the remainder of his life. This venture was undertaken in partnership with his brother Thomas, as forwarder : but it did not prove successful ; for, like Falstaff, Roger Payne preferred his drink to his meat. His appearance was habitually ragged and unkempt ; and his workroom deplorable and squalid. In his latter years, he took Richard Wier, the husband of Mrs. Wier, the celebrated mender of books, to work with him: but Wier inclined to the same weakness as Payne; and in consequence, they were continually quarrelling. Afterwards they parted; but not before Mackinlay, the bookbinder, had taken them under his protection. Roger Payne died on 


\section{English Bindings}

the 2oth November, I797, in Duke's Court, St. Martin's Lane; and his remains were interred in the burying ground of St. Martin's in the Fields, at the expense of Thomas Payne, the bookseller; 'to whom,' says a contemporary writer, 'in a great measure, the admirers of this ingenious man's performances may feel themselves indebted for the prolongation of his life; having for the last eight years provided him with a regular pecuniary assistance. What adds to the credit of this, is, that the poor man had not a proper command of himself; for when in possession of a few pounds he would live jovially; when that was exhausted almost famishing.'

The peculiarities of his forwarding are these : he usually sewed his books with silk; and coated the backs with Russia leather, before covering them, so that his smaller volumes did not always open with ease. For his end papers, he used what he called 'purple paper'; and morocco joints are frequently to be found in his bindings. In covering his books, he commonly used either Russia leather, then lately introduced into England; or straight-grained, olive morocco, which he called Venetian. Such was the state of his penury, that he was often obliged to make his own tools; and those of iron. The backs of his books are, in general, very richly tooled; while the boards are more plainly finished. Each book of his binding was accompanied by a written description of its various details, in a most precise 


\section{$208 \quad$ Bookbinding}

and individual manner. His bill for binding Earl Spencer's copy of the 'Glasgow Æschylus' of I795, in folio, with the original drawings by Flaxman, which I quote from Dibdin, is an admirable example of these remarkable pieces; especially, as it contains many particulars as to his methods of workmanship, and as the binding itself was considered, by his contemporaries, to be his finest work :

Aeschylus. Glasguae, MDccxcv. Flaxman Illustravit. Bound in the very best manner, sew'd with strong Silk, every Sheet round every Band, not false Bands; the Back lined with Russia Leather, Cutt Exceeding Large ; Finished in the most Magnificent Manner Em-border'd with ERMIne expressive of The High Rank of the Noble Patroness of the Designs, the other Parts Finished in the most elegant Taste with small Tool Gold Borders Studded with Gold; and small Tool Panes of the most exact Work. Measured with the Compasses. It takes a great deal of Time, making out the different Measurements; preparing the Tools; and making out New Patterns. The Back Finished in Compartments with parts of Gold studded Work, and open Work to Relieve the Rich close studded Work. All the Tools except Studded points, are obliged to be Workt off plain first,-and afterwards the Gold laid on and Worked off again, And this Gold Work requires Double Gold being on Rough Grain'd Morocco, The Impressions of the Tools must be 


\section{English Bindings}

fitted \& cover'd at the bottom with Gold to prevent flaws \& cracks, . . . . . I2 I2 0

Fine Drawing Paper for Inlaying the Designs, 5s. 6d. Finest Pickt Lawn paper for Interleaving the Designs, Is. $8 d$. I yd $\&$ ahalf of Silk, Ios. $6 d$. Inlaying the Designs at $8 d$. each, 32 DESIGNS, Il. Is. $4 d$. Mr. Morton adding Borders to the Drawings,

$\frac{116-}{£ \text { I6 } 7}$

The great merit of Roger Payne, says Dibdin, lay in his taste, in his choice of ornaments; and, especially, in the working of them. These, in many instances, were chosen in allusion to the subject of the work, or to the age and time of the author. Of this kind are the ornaments upon a copy of William Lilly's Christian Astrology, London, I659, bound for Dr. Benjamin Mosely; of which a plate may be found among Mr. Quaritch's Facsimiles of Bindings [P1. 97.]. In the centre of a panel, formed by a border of crescent moons in small circles, with the sign of Capricornus at the angles, is a cluster of stars surrounding the sign of Saturn: and the whole is further enriched with oak leaves and acorns. The chaste and decorative effect, produced by these simple elements, is very felicitous and distinguished.

Of the same kind is the binding of a Virgil, printed on vellum by Aldus, in I505, on either cover of which a cameo of classic design is character- 


\section{0 \\ Bookbinding}

istically inserted. This little volume, which was bound for the Rev. Mr. Cracherode, and bequeathed by him, among his library, to the British Museum, is covered in blue morocco, with the back, and the angles of the panels of the boards, richly tooled in a manner, which is very characteristic of Roger Payne's gilding. A series of small circlets in various sizes, is carefully disposed, with leaves and other devices, over the space to be ornamented; the remaining portions of the field being richly studded with gold points [C. I9. f. 8.].

The example of his binding, which is figured in Plate vir., a copy of Euripides, printed at Cambridge in I694, is an admirable instance of his more usual manner of gilding. Like the Virgil, it was bound for the Rev. Mr. Cracherode, whose arms and crest it bears; and is preserved among his books in the British Museum [C. I9. e. 3.]. It is covered in dark blue, straight-grained, morocco : and pasted upon one of the fly-leaves, is the following bill for the work, in Roger Payne's own hand-writing, which I here print with all the peculiarities of his orthography :

Euripidis Quæ Extant omnia. very La[r]ge Copy Bound in the very best manner in the finest darkest Blue Turkey Gilt Leaves not cutt. The Back Lined with Russia Leather no false Bands fine Drawing paper Inside of ye Colour of the Book Morrocco Joints Double filleted \& fine Dark purple paper Inside. The Back richly Finished with small Tools in Compartiments very Correct Lettering for Work- 


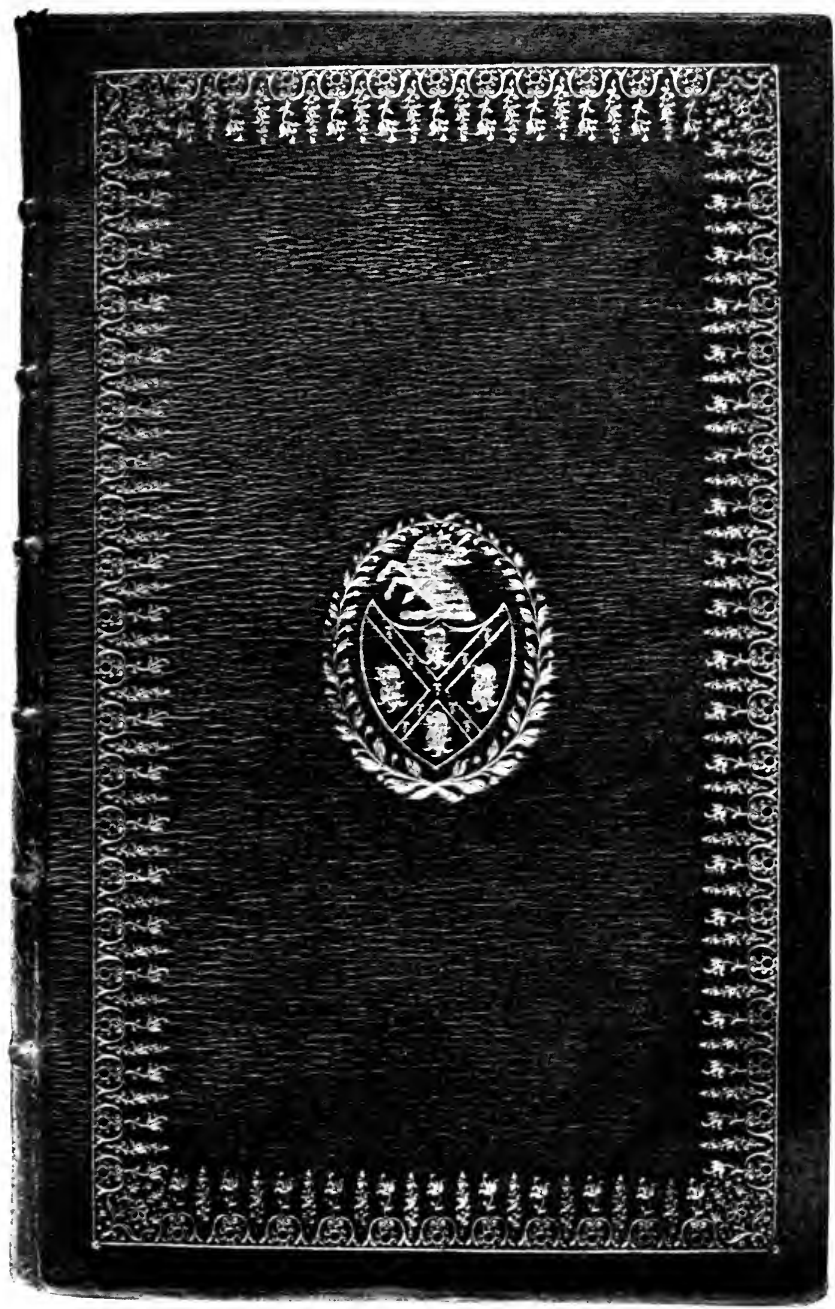

ROGER PAYNE.

(EURIPIDES, 1694.) 



\section{English Bindings}

manship. The out-sides finished with Rich smallTool Gold Borders of measured Work \& Corners Velum \& Morrocco under the Silk Headban[d]s so as never to break very Great care has been taken in the Beating $\&$ beat several times and great care in pressing

$3: 3: 0$

Some Sheets was of a very bad Colour $\&$ had gott the dry rott these are all put to rights \& refreshed NB not any Aqua Fortis has been used in the Washing Some Leaves had been broken by the printing Types these took also a good deal of time to mend them very neat and some Wrinckles which took a great deal of time one leaf for instance page 47 took a full Days Work the Weak Leaves was also very neatly sised, strong and Clean. I : $6: 0$

$4: 9: 0$

It was a very difficult Book To Beat Bind and putt to rights \& is now the Finest \& largest Copy I ever had to do.

If we would properly appreciate the great merit of Roger Payne, we must compare his work, not with the finest productions of the sixteenth or seventeenth century, but with the debased work of the binders, who immediately preceded him, and whose methods he reformed. That scrupulous care for every detail of his art, and that instinct for scholarship, (no matter how little actual scholarship he possessed), 


\section{I 2 \\ Bookbinding}

which are conspicuously illustrated by the foregoing bills, enabled him to lend to his work a distinguished and personal air, and to endue it with more charm and interest, than a greater mastery of forwarding, and a more copious invention, have commonly succeeded in accomplishing. $\mathrm{He}$ had the true temperament of an artist ; for that very sensibility, which led him into excesses, rendered distasteful to him the perfunctory work, with which he found himself surrounded ; urging him on, not only to conceive, but, also, to realise, a finer and better manner in his art. As such, he appeared to his contemporaries: 'those,' observes the writer of his obituary notice, in the Gentleman's Magazine, 'who are not accustomed to see bookbinding executed in any other than the common manner, can have no idea of the merits of the deceased.' 'This ingenious man introduced a style of binding, uniting elegance with durability, such as no person has ever been able to imitate.'

The tradition of fine binding, which Roger Payne had revived, was continued after his death by certain German binders, Baumgarten, Benedict, Kalthoeber, and Staggemier, who settled in London; and, also, by Charles Lewis and Charles Hering, who especially imitated his manner. Lewis did much work for the Rt. Hon. Thomas Grenville, Earl Spencer, the Duke of Devonshire, among other collectors: and was greatly esteemed by Dibdin, who lauded him somewhat to the disparagement of Roger Payne. Lewis was, doubtless, a more reliable workman than Payne; 


\section{English Bindings}

and Dibdin, in his Decameron, has enumerated his virtues: but that estimable writer has forgotten to add, or, perhaps, did not quite appreciate, that Payne possessed, what is above merely technical excellence, original genius, which cannot be said of Lewis. Kalthoeber, who did much work in Payne's manner, revived the art of painting the edges of books, under the gold; a form of decoration, which is more particularly associated with the name of Edwards, a binder of Halifax, who afterwards settled in Pall Mall. In I785, Edwards took out a patent for the decoration of vellum, in covering books, by rendering it transparent, and painting upon the under-surface. A Prayer Book, printed by Baskerville in $\mathrm{I} 76 \mathrm{o}$, which belonged to Queen Charlotte, and which is now in the British Museum, is elaborately decorated in this manner, with a border in the Etruscan style, and painted edges [2. a. I7.].

This style was derived from the ornament on Etruscan vases, by John Whitaker, another binder of this time; in connection with whose name, I may mention those of $\mathrm{H}$. Walther, and $\mathrm{H}$. Falkner. and add that Dibdin speaks at length about the greater number of these successors to Roger Payne, in his Decameron. Clark, famous for his tree-calf, bound for some time with Charles Lewis, and eventually went into partnership with Francis Bedford. This latter binder, with Robert Riviere and Joseph Zaehnsdorf, belong entirely to the nineteenth century. They were admirable workmen, who 
possess the distinction, which has been possible only of recent years, of having finished their books in every style, but their own. The forwarding of Francis Bedford, I should add however, was especially accomplished. Among living binders, there is one workman, of whom I cannot refrain from speaking; since he had done for bookbinding, what Mr. William Morris has done for glass-painting, tapestry-weaving and other decorative arts: I mean Mr. T. J. Cobden Sanderson. Mr. Sanderson left the profession of a barrister for that of a bookbinder: and learned his craft under Mr. Roger de Coverly, one of the most conscientious of living workmen. Until he established a binder's shop at Hammersmith, Mr. Sanderson executed the whole, both of the forwarding, and the finishing of his books, with the exception of the sewing, with his own hands: and therefore his productions have been comparatively few in number. The binding of a copy of the facsimile, issued by Mr. Wise, of the first edition of Shelley's Adonais, executed by him, under these conditions, is figured in Plate vilI. It is covered in orange-red morocco; and both the colour and texture of the leather are of great beauty. Mr. Sanderson's designs are composed of a few simple tools, arranged upon a geometrical plan of equal simplicity, the figured tools being directly copied from natural forms; but the total effect is one of great richness and elaboration. Whatever strictures may be passed upon his work, 


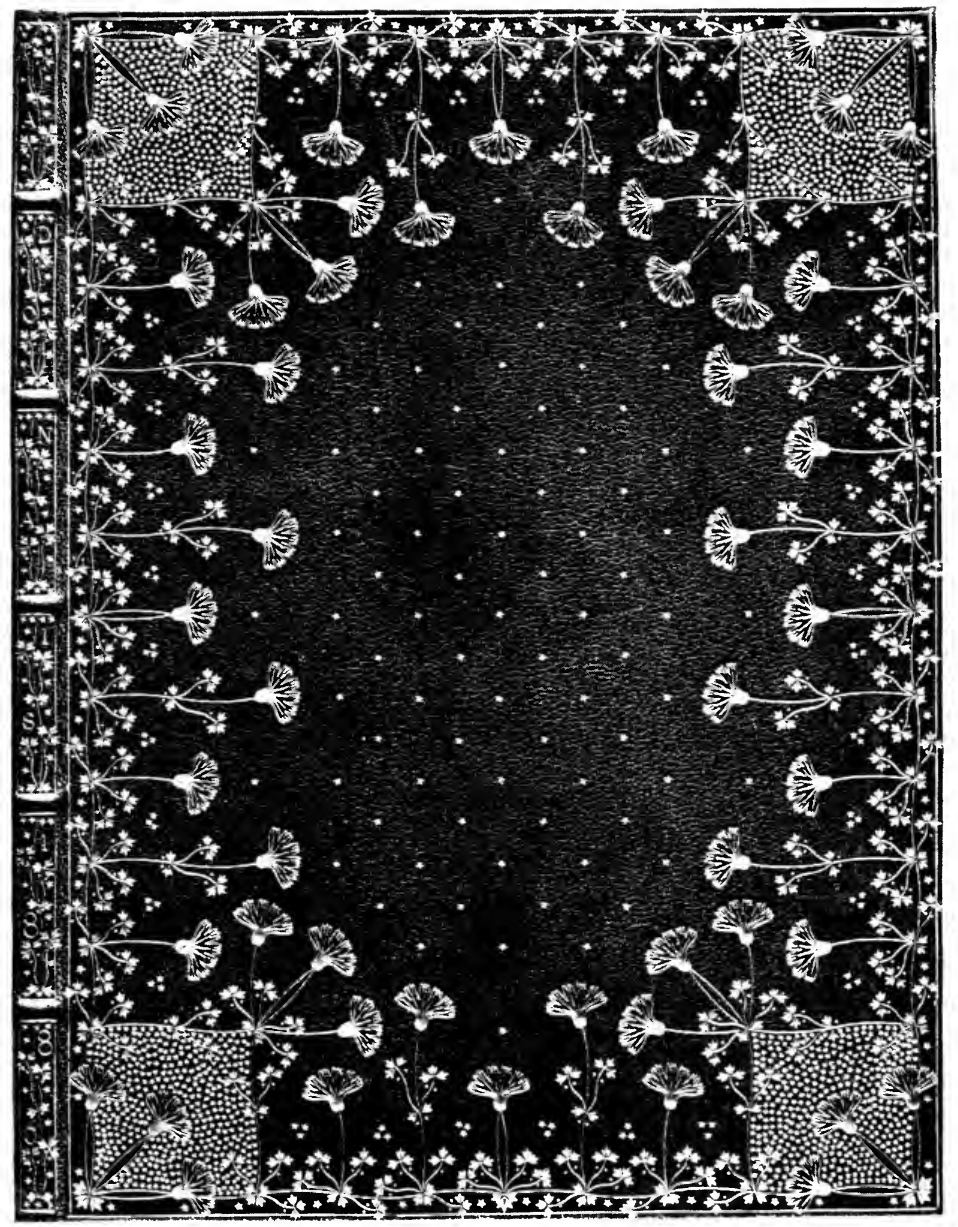

BINDING BY MR. COBDEN SANDERSON.

(SHELLEY'S ADONAIS.) 



$$
z=z
$$




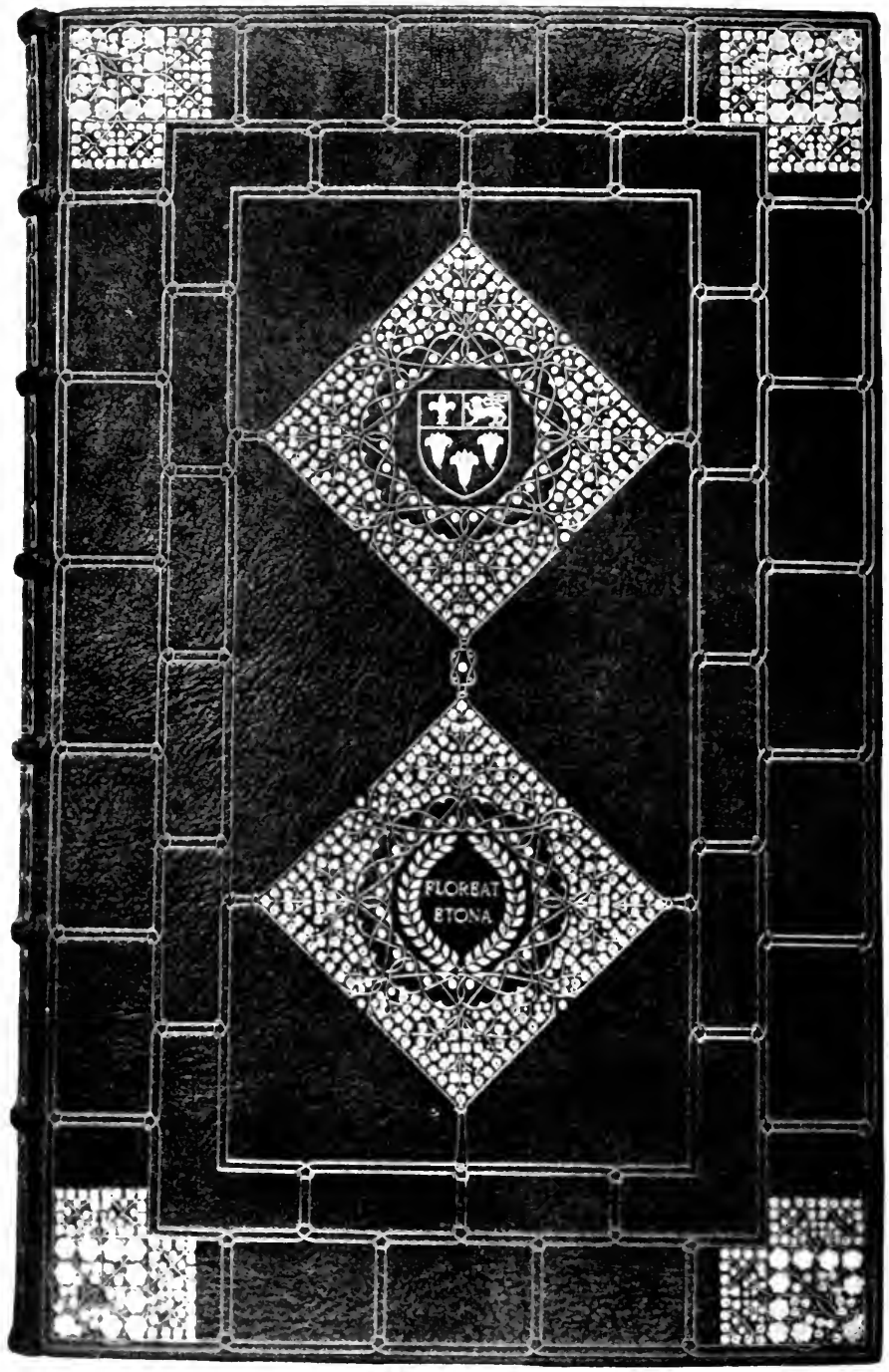

BINDING BY MR. DOUGLAS COCKERELL. (ETON ROLL OF HONOUR.) 


\section{English Bindings}

it cannot be denied, that, like Roger Payne, he has invented a distinguished manner of his own; and that, in his hands, gold-tooling has again become a living art. It is remarkable, that the chief characteristic of the work of these two binders is the one which is hardest to discover in the work of the sixteenth, and seventeenth, centuries, a trait of personality, of individual distinction.

Within the last twenty years, a new generation of bookbinders have grown up, who have succeeded in liberating the art of finishing in this country, from the narrow conventions and banal taste, which had characterized it, during the MiddleVictorian period. The most remarkable of these younger binders, almost without exception, owe their inspiration, either to the personal teaching, or to the example, of Mr. Cobden Sanderson, or Mr. Douglas Cockerell, one of Mr. Sanderson's earliest and most successful pupils. An example of Mr. Cockerell's binding, a Roll of Honour, executed for Eton College, is reproduced in Plate IX. 


\section{CHAPTER V}

CONCLUSION

Finem loquendi pariter omnes audiamus. The art of bookbinding depends, therefore, as I have endeavoured to show, upon a prolonged series of minute particulars; the whole of which must be managed with taste and skill, if the binder would produce a fine and accomplished work. Of these particulars, those, which relate to that part of his craft technically known as 'forwarding,' are of greater importance, than those, which relate to the more attractive process of 'finishing.' Forwarding is the structure of bookbinding; while finishing is merely the decoration of that structure. The first and fundamental condition of good forwarding is beyond the control of the binder, and consists in a proper choice of the paper upon which the book is printed. Unless the substance of the paper has been determined by the size and number of the quires, which is rarely the case of modern editions, it is impossible to bind a book in a proper manner. A book, of which the paper has allowed it to be well forwarded, should be solidly pressed, but not crushed or killed in the pressing : its sections should be sewn round the cords; and it should be furnished 


\section{Conclusion}

with boards, whose substance and squares are agreeable to its size and weight. The back should be of a nature, that will allow the book to open, to remain open and to shut, with ease; the edges accurately cut ; the boards lying solidly and evenly upon the body of the sections: while the joints, head-bands and mitres should be formed with nicety and precision; and the binding, in these, as in all other, particulars, be strongly and truly made. If, in a well forwarded book of this kind, the colour of the end-papers and head-bands, the decoration of the edges and especially the colour and texture of the leather, have been chosen with the same taste and judgment, which should have determined the other details of the forwarding, a very slight amount of tooling, either in blind or gold, is sufficient to render its binding a fine and satisfactory work of art : and of this, the little copy of Claudian, in the British Museum, which was bound for Baron de Longepierre, and is tooled with his device of the Golden Fleece, as well as some of the simpler bindings of Padeloup, are conspicuous examples. Even the most wealthy of collectors cannot hope to have any considerable number of his books more elaborately gilded than these.

The notion, that the ornament of the binding should symbolise, or in some way be expressive of, the contents of the book, has been traced to medieval times. At the close of a translation of Boccaccio's Falles of Princes, by Dan John Lydgate, Monk of 


\section{I 8 Bookbinding}

Bury, London, 1554 , is a leaf entitled 'Greneacres, a Lenuoy vpon Iohn Bochas,' in which the translator thus addresses his book:

'Blacke be thy bondes \& thy wede also Thou sorrowefull Booke of matter dysespeyred :

In Token of thine inward mortall woe, Which is so bad it may not be impeyred. Thou owest not outward to be feared, That inward hast so many a ruful clause, Such be thine habite of colour as of cause.

' No cloth of Tissue ne veluet Cremesyne But like the monke mourning vnder his hode Goe weyle and wepe with woeful Proserpine And lat thy teres multiplye the floode Of black Lithey vnder the bareyn woode Where she as goddess hath her Hermitage, Help her to wepe \& she wil gene the wage.'

But early instances of this kind are altogether exceptional; and we must turn to certain inlaid bindings, executed in France during the last century, for any general illustration of the notion, that the decoration of a book should be expressive of its contents. By Roger Payne, this principle was observed, as I have shown, in a great number of his books: but it has remained, however, for the binders of a yet more recent time to pursue it to its logical conclusion; although rarely with conspicuous success, if the bindings figured in M. Octave Uzanne's work, La Reliure Moderne, are to be taken as representative examples. At the present day, the notion has been carried to an extreme by some 


\section{Conclusion}

designers, who, affecting the fashion of the Décadents, appear to work in a spirit akin to that of Arthur Rimbaud's sonnet, which finds in colours some definite equivalent of language.

Some of the bindings executed by $\mathrm{Mr}$. Cobden Sanderson afford a good modern instance, of how a design may find its suggestion in some passage or motive of the book, which it is intended to decorate. He has himself told us, how Tennyson's line, the ' grassy barrows of the happier dead,' suggested the bands of daisies with which he decorated a copy of 'In Memoriam': and how, in a similar way, the design upon a binding of 'Atalanta in Calydon' was suggested by the subject of the poem, and especially by the dream of Althaea the mother of Meleager.

'I dreamed, that out of this my womb had sprung Fire and a fire-brand, ...

And I with gathered raiment from the bed Sprang, and drew forth the brand, and cast on it Water, and trod the flame bare-foot, and crushed With naked hand spark beaten out of spark, And blew against and quenched it ;

$$
\text { ... again }
$$

I dreamt, and saw the black brand burst on fire As a branch bursts in flower.'

'These lines,' Mr. Sanderson adds, 'haunted me when I thought of the pattern of the cover, and came out, as will be seen, in the decoration. For the flame I used a seed-pod, which I had ready at hand, and for the leaves a quivering heart, and I blent them together in the form of a brand that bursts on fire, 


\section{0 \\ Bookbinding}

" as a branch bursts into flower," and I set them torch-wise around the margins of the green cover, green for the young life burning away.' Mr. Sanderson is not always careful to preserve this elaborate kind of connection between the book and the design of its binding: though, as he elsewhere adds, 'some subtle relation there may be, and, I think, should be, between the inside, and the outside, of a book, between its contents and ornamentation; and in my opinion, no one can produce a right design for a book, who knows nothing about the book. Still this relation is not a definite one, nor should it make itself too plainly felt in the design: in a word, it should not be allegorical or emblematical.'

Allusive ornament of this kind is rarely met with upon bindings, executed before the middle of the eighteenth century. Allusions to their owners, by way of cyphers, arms or other heraldic devices, were, as I have shown, in common use upon gold-tooled bindings, since the beginning of the sixteenth century. Other allusive ornaments, such as the busts of Plato, Dido or Caesar, were used in a general way; and though not inappropriately, yet without any immediate reference to the book on which they occur. The custom of the early binders, in this regard, was to employ the styles, which were in vogue, alike upon religious and secular books; but such styles, during the sixteenth and seventeenth centuries, were, in their manner, always agreeable to 


\section{Conclusion}

the gravity and dignity of Letters, and therefore not misplaced upon any literary work.

The motive, then, of the gilding, which occurs upon tooled-bindings from the time of the introduction of the art into Europe, until the middle of the eighteenth century, was, with the exception of the lettering and allusions to the owners of the book, entirely a decorative one; while the manner in which it was designed was agreeable to the architectonic spirit, which distinguished the arts of design in those ages. If we consider these bindings, in a general way, we shall find, almost, I think, without exception, that the ornament of the boards was symmetrically distributed upon a geometrical plan, or framework, and that its excellence consists in the taste and invention shown in the contrivance of this plan; as well in the choice, as in the simplicity, mass, distribution and harmonious relation, of the various elements, which compose its design. It was for the age of Derome and Lemonnier to depart from this principle of symmetry, and to employ on its books, compositions, which were unfettered by any architectonic restraint; a liberty of design, which has been carried to an extreme, in France, during the present century. Whether, or no, it is possible to invent, with such license, a pattern for the decoration of a book, which shall be at once fine and distinguished, yet proper to the materials in which it is worked, remains to be seen : but, without doubt, there are certain large and severe qualities of design, 
which would seem inseparable from the architectonic principle of symmetry.

The decoration upon the back of a book must be designed according to the principles, which have determined the decoration of its boards; that the whole may be brought into agreement. The treatment of the back is less often managed with success, than that of any other part of the book. The Italians, who availed themselves of the bands, as their chief means of decoration, more generally succeeded than the French: and even in such accomplished pieces of art as the bindings attributed to Le Gascon, the decoration upon the back is rarely equal to that of the boards.

The first practical step towards the gilding of a book, is to determine the texture of the leather. If the field of the boards be left untooled, except for some slight ornament, a coarsely grained leather may be used with effect : but it is difficult to work fine and elaborate gilding upon a skin of this nature. Despite the practice of Roger Payne, and other modern binders, in this regard, the surface of the leather should, I think, be left in a condition, which will allow the gilding to be solidly worked with ease and directness. The morocco leathers used by the early Italian and French gilders, upon their most finished work, were invariably smooth and fine in texture ; and admirably suited to receive the elaborate ornament with which they are decorated. A coarsely grained leather requires to be handled with 


\section{Conclusion}

skill, during the process of covering; but a smoothly grained leather, especially if it is not intended to be covered with gilding, must be chosen and manipulated with more than ordinary knowledge and care. As to the colour of the leather, that is entirely a matter of taste; et de gustibus non est disputandum; but what admirable material and effect may be obtained, by a judicious selection and use of the best skins in the open market, is conclusively shown by not a few of the bindings of Mr. Cobden Sanderson.

The next step is to determine the nature of the tools, with which the gilding is to be worked. Those used by the early Venetian binders partook largely of the nature of the ornaments, or 'flowers,' employed by the contemporary printers with their type. Upon the finest bindings executed for Grolier, when the design of the tools was for the first time perfectly adapted to the necessary conditions of fine gilding, figured tools were rarely used, or not at all ; and the pattern was entirely worked by fillets and gouges. From this period, the gilders' tools became more and more complex in their design, until they reached the furthest point of elaboration, consistent with good art, in the work attributed to Le Gascon. Without doubt, the finest and most satisfactory kind of gilding is that, which is entirely executed by small and simple tools: while the use of stamps, or of tools whose elaboration is such that they approach to the nature of stamps, side by side with small tools, or 


\section{$224 \quad$ Bookbinding}

'petits fers,' is always more or less unpleasing in effect.

The binding by Mr. Cobden Sanderson, which is figured in Plate viri., is a good example of what simple elements, a rich piece of gilding may be composed. Impressions of the whole of the gouges and figured tools, which were used in working this design, are reproduced at their full size, in Fig. 3.

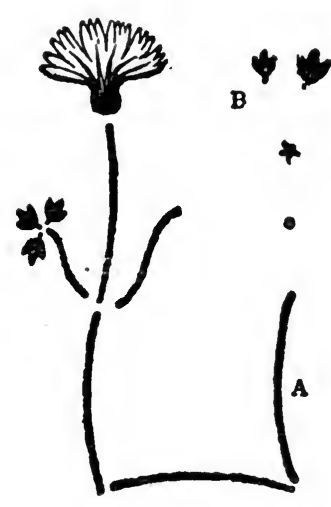

FIG. 3.

The design of this binding is composed of a geometrical, and symmetrical, plan or framework, about which its ornament is disposed. This plan, or framework, is entirely constructed by the single gouge, marked $\mathrm{A}$ in Fig. 3, variously repeated; to which the smaller gouges, and the figured tools, are but ornamental accessories. The flower is worked, as will be seen, by a single tool : and trefoil leaf, by the repetition of the tool marked B. In this way, both the tools themselves, and the principle of Mr. Sanderson's design, are reduced to the fewest and simplest elements. The mass of the several tools, I need scarcely add, is to be determined by the nature of the design, considered in relation to the size of the book.

It is desirable, in working a rich piece of gilding, that the figured tools should be of an elemental 


\section{Conclusion}

nature, because such tools are capable of the greatest number of combinations; and it is necessary, that they should be small, as well as simple, so that every part of them may be seen without difficulty in making an impression ; for, unless they can be worked with ease and directness, it is impossible to give that expression to the gilding, in which the virtue of the art consists. No more false standard of excellence was ever set up with regard to an art, than that which at the present time prevails, especially in France, with regard to gold-tooling. The geometrical accuracy, and unfailing sharpness, of each part of the design, as well as the absolute solidity of the gold in every.impression, which this standard of excellence requires, and which involves an extraordinary expense of skill and patient labour, can only result in a dead and mechanical effect. A tooled binding worked in this uninteresting manner, can have scarcely more artistic value, than a fine stamped binding. Whatever difference there may be between the two, it cannot, certainly, justify the expenditure of so much skill and labour, as are necessary to produce the former. A piece of tooled gilding, upon the other hand, worked with that directness, and with that expression, which can only follow upon real invention, is as much above a piece of stamped gilding, however admirable in design and execution, as a fine mezzotint is above the best photogravure: and unless gold tooling is worked with such directness and expression, there is no good reason why so much 


\section{$226 \quad$ Bookbinding}

skilled labour should be expended upon a work, which, except for the purposes of the bookseller and the collector, could be as well executed by a block or stamp.

Of the invention of new designs for the decoration of books, it is more difficult to speak. Certainly, no invention, which is worth the name, can exist where the workman has not taken pleasure in his work.

'What poets feel not, when they make,

A pleasure in creating,

The world, in its turn, will not take

Pleasure in contemplating.'

And not only in poetry is this true, but in every other fine art. Pleasure in creating, consequent upon the desire to produce, is one of the first conditions, which are necessary to fine invention; and that condition, precisely, which is the hardest to be met with in the modern binder's shop. To discuss how far this state of things is owing to the present system of distributing, among different workmen, the successive stages of the craft, would necessitate a disquisition upon the economics of bookbinding, which would here be out of place : but the present want of invention, and servile habit of copying what has already been done, and done to admiration, would seem to be entirely attributable to this unfortunate condition of things. It does not require any profound critical insight, to perceive how futile are these attempts to revive a past style. No man can escape the spirit of the age 


\section{Conclusion}

in which he lives: the modern gilder, in imitating some old binding, is not able, as he supposes, to reproduce the spirit of the original ; he only betrays his own want of invention, and his copy remains, for all his labours, the mechanical production of his own time.

The great styles, such as those which are associated with the names of Grolier, or Le Gascon, have been elaborated to their utmost extent. They are incapable, I think, of further development, or of finer expression : they are among the finished achievements of Art. Yet, upon the other hand, a careful study of the finest bindings, which have been done, is necessary to the successful invention of new styles: for by such study alone can the true principles of design, and the nature and extent of the various technical methods of bookbinding, be fully understood. A disregard of principles and precedents cannot lead to originality, but only to fantasticalness, which has no real connection with Art.

In England, especially, where we are at length endeavouring to print our books in a manner worthy of our literature, it is important, that the binder's art should not be neglected : for it is only when the book, the impression and the binding are the productions of the same time, and of the same influences, that the art in its finest and most satisfactory condition is possible. A copy of the Hypnerotomachia, in the types of Aldus, with its original Venetian binding, or the Adonais of La Fontaine, in the manuscript of 


\section{Bookbinding}

Jarry, bound by Le Gascon, have, for instance, an unique charm and incomparable interest: they are, in their several ways, wholly of their own time, perfect works of art. But before modern binding can attain to such excellence, we must learn to print our books finely, in a manner which shall be of our own time, and which, by its excellence, may enable our binders to do work of equal excellence: until this is done, it is impossible, that bookbinding can become again, in any general sense, a living art. 


\section{N D E X}

Acland Troyte, Mr., quoted, I95.

Act of 1533,173 .

Aldus Manutius, 60-7 I, 74-76, $78,79,83$.

Anne of Austria, 148 .

Arundel, Earl of, 182.

Asulanus, Franciscus, 74, 75.

BACKING, I 7-24.

Badier, Florimont, I 38-145.

Bagford, John, $x$.

Ballagny, 102.

Bands, 8.

Barbançon, Marie, 129.

Barker, C., 177.

Barker, R., 184.

Bateman, J. and A., I 84 .

Bauchart, M., quoted, xii, I 12 , I 3 .

Bauzonnet, 162.

Beating, 4.

Bedford, F., 2 I4

Berri, Madame de, 155.

Berthelet, T., I64-169, I 70, I 7 I. Blind-tooled Venetian bindings, 57-59.

Boards, 24-26.

Boleyn, Anne, 180.

Boot-gilding, 102.

Bowman, F., 196.

Boyet, L. A., I49-1 52, I55-1 59.

Bozérian, 162.

Bradel, A. P., I62.

Burleigh, Lord, I 72, 183.
CAESAR, Sir Julius, 188.

Cameo bindings, 93-96.

Canevari, Demetrio, 95-96.

Capé, I62.

Casing, 2.

Castle, E., 2or.

Cawood, J., 177.

Chapman, 204.

Charles I., I87-1 89.

Charles Ir., 196-198.

Charles IX., II 9.

Chastre, Gasparde de la, 130.

Churchill, W., 201.

Clark, 2 I 3.

Cloth bindings, 44-45.

Cobden Sanderson, Mr., xi, 2 I 4 , $219,220,223,224$.

Cockerell, Douglas, 215 .

Colbert, I 22.

Collation, 3 .

Cosin, Bp., 200.

Cottage style, 198, 202-203.

Covering, 4I.

Coverly, Roger de, 43.

Cracherode, Mr., 2 ro.

Cusson, J., I 49.

Cutting, 28-31.

Cuzin, 162 .

DAY, John, I78, 179.

Dentelle borders, 159.

Derome, J. A., I61, 221.

Derome, N. D. (Le Jeune), $16 r$.

Diane de Poitiers, I I I-I 7 .

Digby, Sir Kenelm, I30-13I. 


\section{$230 \quad$ Bookbinding}

Doublures, 48, I $50,159$.

Douceur, L., 160.

Drobet, G., I 24.

Dubois, G., I 49, I 52.

Dubois, L. J., 155.

Dubuisson, B. B., 160.

Dudin, M., viii, ix.

Dudley, R. See Leicester, Earl of.

Duru, 162.

Du Seuil, A., I 32, I 53-I 58.

EDGES, decoration of, 3I-38.

Edward vi., i68-i 70 .

Edwards of Halifax, 213.

Elizabeth, Queen, 67, 177-1 79.

Eliot, 204.

End-papers, I2-I 5 .

English bindings, Chap. IV.

Eve, Clovis, 20, 25.

Eve, Nicholas, 20, I19-124.

Evelyn, John, 199, 200.

FAN style, 202.

Ferrar, N., I 89-196.

Finishing, 49-54.

Fitzalan, H. See Arundel, Earl of.

Fletcher, W.Y., Mr., xii, xiii, 94.

Florentine binders, 96-98.

Folding, I.

Foreign binders in England, I 75-I 77 .

Foucaut, Jehan, II 4.

François I., 105-108.

François II., 118.

French bindings, Chap. III.

GAFORUS, F., 72.

Gauffecourt, J. V. Capronnier de, ix.

Gauffered edges, 32-34.

George III., 202.

Gibson, J., I 84.
Gillede, J., I4I.

Gilt edges, 32-33.

Giunta, Filippo di, 62, 64 .

Gold tooling, origin of, 56-60.

Grafton, R., I68, 177 .

Grolier, Jean, life, 7 I-75.

Grolier bindings, I I, 70, 75-84, I $17,137$.

Gruel, M., quoted, xii, 141 .

Guild of St. Jean Latran, 99I05.

HANNETT, John, $x$.

Harleian style, 204.

Head-banding, 38-41.

Henri II., III-I I 5, II 7 .

Henri 111., 121, 123.

Henri IV., I 28.

Henry vili., I64-I67.

Henry, Prince of Wales, I82, I 87.

Hentzner, P., 180.

Hering, C., 2 I 2.

Hollis, T., 205.

Hollow backs, 18-19.

Howard, Lord, 183.

Hoym, Count d', I 59.

Hutchinson, H., 200.

I. D. P., I 79 .

Inlaid bindings, English, 203.

—- French, 160, 16I.

Interlaced fillets, $7 \mathrm{I}$.

Italian bindings, Chap. II.

JAMES I., I 84-187.

Jansenist bindings, I 50.

Jaugeon, M., ix.

Jubert, J. P., 162.

Jugge, R., I 77 .

KALTHOEBER, $212,213$.

Katherine de Medicis, 114,115 , I1 $8,119,124$. 


\section{Index}

LACING, 26, 28.

Laferté, F., I62.

Lauwrin, Marc, 89-90.

Leathers, $4 \mathrm{I}-47$.

Le Faulcheur, ro8.

Le Gascon, 2, I 38-1 46, 222.

Leicester, Earl of, I 83 .

Le Mire, C., I49, I 52.

Le Monnier, J. C. H., I60, 221.

Le Roux de Lincy, quoted, xi, 73.

Lessée, I62.

Lewis, Charles, 2 I 2.

Libraires-relieurs, 103.

Linde, A., 202.

Little Gidding books, I89196.

Lomenie, L. H. de, I 54, I56, I 57 .

Longepierre, Baron de, I5I, 217.

Lortic, 162.

Louis XI., IOo.

Louis XII., I05.

Louis XIV., I 48.

Louise de Lorraine, I $2 \mathrm{I}$.

Louvet, J., I I 5 .

Lydgate, quoted, 218.

Maiolus, Thomas, 84-89.

Mallard, O., I I I.

Marbling, 15.

Marguerite de Valois, I27.

Marking-up, 5, 24.

Maxwell, Sir William Stirling-, 43.

Mary, Queen of England, I 7I. Mary, Queen of Scots, I I 8.

Mearne, S., 197-199.

Mettayer, P., I 26.

Michel, MM. Marius, quoted, xii, I 4 I.
Monnier. See Le Monnier.

Morocco, 42.

NIÉDRÉE, I 62.

Norton, J., 184 .

Notts, 200.

Oriental Bindings, 66-68.

Padeloup, A. M. (Le Jeune), I 50, I 57-160.

— P., I55.

Painted bindings, 91, 92.

Painted edges, 34-37.

Parker, Archbishop, I 78, I 79.

Payne, Roger, 44, 206-2 I 2 , 2 I 8 , 222.

Peiresc, N. C. Fabri de, 83, I 32I 37, I 39.

Picques, C., I I 9.

Pigoreau, 102.

Pressing, 4.

Prideaux, Miss, viii, xi.

Purgold, 162.

RIVIERE, R., 213.

Roffet, E., I06-107.

Roundels, 58.

Rounding, $2 \mathrm{I}$.

Ruette, A., I46, 147 .

Ruette, Macé, I 5, I46, I47.

Russian leather, 44.

Saint Remy, Marie Marguerite de Valois, 127.

Savary-Desbrulons, J., $\mathbf{x}$.

Séguier, D., I 45.

Seile, H., 196.

Semis, I 9.

Sewing, 5 .

Silver-leaf, 53 .

Stamped bindings, 93-95.

Stamps, 49.

Stanley, Venetia, I 3I.

Sunk panels, 67-68. 
Thibaron, 162.

Thick paper, 7 .

Thoinan, M. E., quoted, Chap. III., passim.

Thou, J. A. de, 43, 123, 129, I 30. Thouvenin, 162 .

Titles written on fore-edge, 35 . Tools, 49.

Tory, Geoffroy, 72, 108-II 1. Trautz, 162.

UZanNe, OCtaVe, I62, 218.
Vecellio, Cesare, 34.

Vellum guards, II.

Vente, P., 162.

Vingtrinier, Aimé, 85, 88.

Villars, N. de, 127.

WHITAKER, J., 2 I 3.

Whitgift, Archbishop, 183.

Wier, R., 206.

Wotton, T., 177, 181-182.

ZAEHNSDORF, $x, 10,213$. 


$$
=
$$




\section{4.}

- 


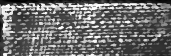

